\title{
Experimental Analysis of a Single Cell Flowing Electrolyte-Direct Methanol Fuel Cell
}

\author{
by \\ Nasim Sabet-Sharghi \\ A Thesis submitted to \\ the Faculty of Graduate Studies and Research \\ in partial fulfilment of \\ the requirements for the degree of \\ Master of Applied Science
}

Ottawa-Carleton Institute for

Mechanical and Aerospace Engineering

Department of Mechanical and Aerospace Engineering

Carleton University

Ottawa, Ontario, Canada

August 2011

Copyright (C)

2011 - Nasim Sabet-Sharghi 
Library and Archives

Canada

Published Heritage Branch

395 Wellington Street

Ottawa ON K1A ON4

Canada
Bibliothèque et

Archives Canada

Direction du

Patrimoine de l'édition

395 , rue Wellington

Ottawa ON K1A ON4

Canada
Your file Votre référence

ISBN: 978-0-494-83051-2

Our file Notre référence

ISBN: 978-0-494-83051-2
NOTICE:

The author has granted a nonexclusive license allowing Library and Archives Canada to reproduce, publish, archive, preserve, conserve, communicate to the public by telecommunication or on the Internet, loan, distribute and sell theses worldwide, for commercial or noncommercial purposes, in microform, paper, electronic and/or any other formats.

The author retains copyright ownership and moral rights in this thesis. Neither the thesis nor substantial extracts from it may be printed or otherwise reproduced without the author's permission.
AVIS:

L'auteur a accordé une licence non exclusive permettant à la Bibliothèque et Archives Canada de reproduire, publier, archiver, sauvegarder, conserver, transmettre au public par télécommunication ou par l'Internet, prêter, distribuer et vendre des thèses partout dans le monde, à des fins commerciales ou autres, sur support microforme, papier, électronique et/ou autres formats.

L'auteur conserve la propriété du droit d'auteur et des droits moraux qui protège cette thèse. $\mathrm{Ni}$ la thèse ni des extraits substantiels de celle-ci ne doivent être imprimés ou autrement reproduits sans son autorisation.
In compliance with the Canadian Privacy Act some supporting forms may have been removed from this thesis.

While these forms may be included in the document page count, their removal does not represent any loss of content from the thesis.
Conformément à la loi canadienne sur la protection de la vie privée, quelques formulaires secondaires ont été enlevés de cette thèse.

Bien que ces formulaires aient inclus dans la pagination, il n'y aura aucun contenu manquant.

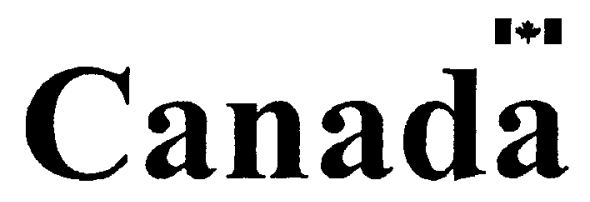


The undersigned recommend to the Faculty of Graduate Studies and Research acceptance of the Thesis

\title{
Experimental Analysis of a Single Cell Flowing Electrolyte-Direct Methanol Fuel Cell
}

\author{
Submitted by Nasim Sabet-Sharghi \\ in partial fulfilment of the requirements for the degree of \\ Master of Applied Science
}

Dr. Edgar Matida, Co-supervisor

Dr. Cynthia Cruickshank, Co-supervisor

Dr. Metin Yaras, Department Chair

Carleton University

2011 


\section{Abstract}

Extensive research has been conducted on direct methanol fuel cells (DMFC) in the past two decades. Direct methanol fuel cells are mostly considered for small electric vehicles and portable applications due to their high energy density and simple operating systems. One of the limitations with DMFCs is that the methanol fuel diffuses from the anode to the cathode through the polymer electrolyte membrane (PEM), e.g., Nafion ${ }^{\circledR}$. As a result, the methanol may oxidize at the cathode and cause a serious overpotential loss and result in decreased performance. It is possible to remove the crossed over methanol by using a liquid electrolyte flow between the electrodes. This type of fuel cell is called a flowing electrolyte-direct methanol fuel cell and was used in this study. This fuel cell consisted of parallel serpentine channels for the methanol and air passages, and microporous material as the flowing electrolyte channel. The active area of the fuel cell was $25 \mathrm{~cm}^{2}$. It was found that upon stopping the flowing electrolyte, the open circuit voltage of the cell would drastically decrease due to methanol crossover. Different combinations of Nafion ${ }^{\circledR}$ N117 and NR-212 (7 and 2 mil, respectively) were analyzed and results compared. In the case of a regular DMFC, although thinner Nafion ${ }^{\circledR}$ has lower resistance, it would allow more methanol crossover. Effects of the flowing electrolyte channel design, thickness, and sulfuric acid concentration on the performance of the cell were also studied. It was observed that a thicker flowing electrolyte channel results in lower power density. Finally, a sulfuric acid concentration of 2 molar (18\%) was found to be the most advantageous. 
Dedicated to my Mom and Dad for their love and support. 


\section{Acknowledgments}

I would like to express my deep and sincere gratitude to my supervisors, Dr. Cynthia Cruickshank and Dr. Edgar Matida from the Mechanical and Aerospace Engineering Department at Carleton University, and Dr. Feridun Hamdullahpur from the University of Waterloo, for giving me the opportunity to work on this project and also for their patience, support, and guidance throughout this project.

I would also like to thank the staff at the Mechanical and Aerospace Department office and the machine shop for their help. I wish to extend my warmest thanks to the FE-DMFC team.

This thesis would not have been possible without the financial support from OCE (Ontario Centres of Excellence) and NSERC (Natural Sciences and Engineering Research Council of Canada).

Last but not least, I would have not been able to achieve any of my successes if it was not for the support of my parents, Laleh and Vahid, and my sister, Negin. Their constant encouragement and love keeps me motivated. 


\section{Table of Contents}

Abstract

Acknowledgments $\quad$ v

Table of Contents vi vi

List of Tables $\quad$ x

List of Figures $\quad$ xi

Nomenclature $\quad$ xiv

1 Overview 1

1.1 Introduction . . . . . . . . . . . . . . . . . 1

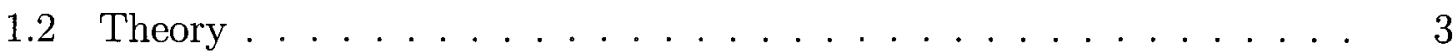

1.3 Characteristics of fuel cells . . . . . . . . . . . . . . 8

1.4 Application of fuel cells . . . . . . . . . . . . . . . . 9

1.4.1 Portable sector ....................... 9

1.4.2 Transportation sector ................ 10

1.4 .3 Stationary sector ...................... 10

1.5 Types of fuel cell . . . . . . . . . . . . . . . . 10

1.6 Direct methanol fuel cells . . . . . . . . . . . . . . . . . 12

1.6.1 Methanol as a fuel ................. 13 
$1.6 .2 \quad$ DMFC reactions $\ldots \ldots \ldots \ldots \ldots \ldots$

1.6.3 Methanol intermediate steps . . . . . . . . . . . . . . . 14

1.6.4 Characteristics of DMFC $\ldots \ldots \ldots \ldots \ldots$

1.7 Flowing electrolyte-direct methanol fuel cell $\ldots \ldots \ldots$

1.8 Objectives . . . . . . . . . . . . . . . . . . . . 21

2 Literature Review $\quad 23$

2.1 Reactant distributor plates . . . . . . . . . . . . . . . 23

2.1 .1 Plate material . . . . . . . . . . . . . . . 23

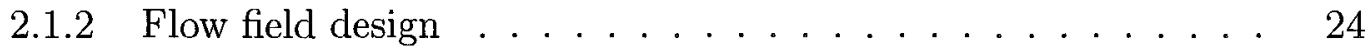

2.2 Membrane electrode assembly . . . . . . . . . . . . . . 27

2.2 .1 Membrane . . . . . . . . . . . . . . . 27

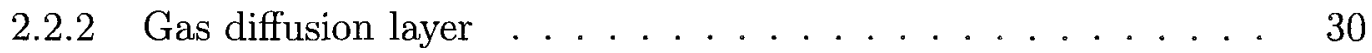

2.2 .3 Fabrication method . . . . . . . . . . . . . . . . 31

2.3 Flowing electrolyte $\ldots \ldots \ldots \ldots \ldots \ldots \ldots \ldots$

3 Flowing Electrolyte-Direct Methanol Fuel Cell Design 35

3.1 Single cell components . . . . . . . . . . . . . . . . . 35

3.1 .1 End plates. . . . . . . . . . . . . . . . 37

3.1.2 Polytetrafluoroethylene (PTFE) sheets . . . . . . . . 37

3.1 .3 Current collector . . . . . . . . . . . . . . . 37

3.1.4 Reactant distributor plate . . . . . . . . . . . . 38

3.1 .5 Electrodes . . . . . . . . . . . . . . . . . . . 41

3.1.6 Membrane . . . . . . . . . . . . . . . . . . . . . . 42

3.1 .7 Gaskets . . . . . . . . . . . . . . . . . 42

3.1.8 Flowing electrolyte channel . . . . . . . . . . . . . 43

3.2 Fabrication and assembly . . . . . . . . . . . . . . . . 44

$3.2 .1 \quad$ Nafion ${ }^{\circledR}$ hydration . . . . . . . . . . . . . . . . . . 44 


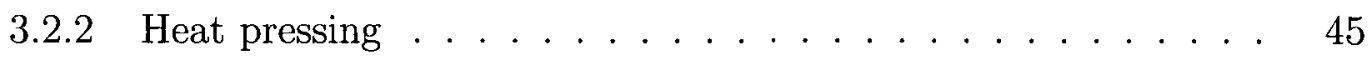

3.2 .3 Assembly . . . . . . . . . . . . . . . . . 46

3.2 .4 Hydration process . . . . . . . . . . . . . . . 47

4 Experimental Setup and Uncertainty Analysis 49

4.1 Experimental setup . . . . . . . . . . . . . . . . . . . . . 49

4.1 .1 Fluid control . . . . . . . . . . . . . . . . . 51

4.1 .2 Temperature control . . . . . . . . . . . . . 54

4.1 .3 Electrical load . . . . . . . . . . . . . . . 56

4.2 Uncertainty analysis of the measurement $\ldots \ldots \ldots \ldots$. . . . 57

5 Effects of Operating Conditions on the Performance of the Fuel Cell 59

5.1 FE-DMFC performance $\ldots \ldots \ldots \ldots \ldots 6 \ldots$

5.1 .1 Repeatability of results . . . . . . . . . . . . 62

5.2 Effects of flowing electrolyte . . . . . . . . . . 63

5.2.1 Effects of flowing electrolyte concentration . . . . . . 65

5.2 .2 Effects of flowing electrolyte flow rate . . . . . . . 67

5.2.3 Effects of flowing electrolyte channel thickness . . . . . . 69

5.2.4 Effects of flowing electrolyte pressure . . . . . . . . 71

5.3 Effects of methanol concentration . . . . . . . . . . . 72

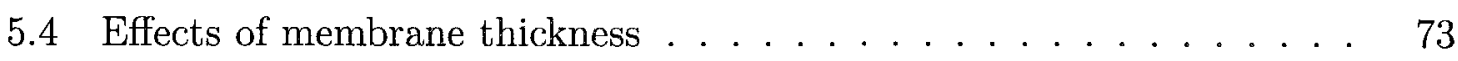

5.5 Temperature effects . . . . . . . . . . . . . . 75

5.6 Effects of methanol flow rate . . . . . . . . . . . 77

6 Conclusions and Recommendations $\quad 79$

6.1 Contributions and conclusions . . . . . . . . . . . . . . 79

6.2 Recommendations . . . . . . . . . . . . . . . . 81

$\begin{array}{lc}\text { List of References } & 83\end{array}$ 
A.1 Method . . . . . . . . . . . . . . . . . . . . 89

A.1.1 Theory . . . . . . . . . . . . . . . . . . 89

A.2 Results . . . . . . . . . . . . . . . . . . . . 92

A.2.1 Meshing . . . . . . . . . . . . . . . . . 92

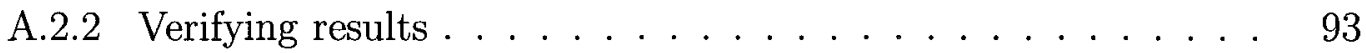

A.2.3 Different Reynolds numbers . . . . . . . . . . . . . . 93

A.3 Conclusion . . . . . . . . . . . . . . . . . . . . . . . 95

$\begin{array}{ll}\text { Appendix B Drawings } & 96\end{array}$

$\begin{array}{ll}\text { Appendix C Temperature controller wiring } & 101\end{array}$

$\begin{array}{ll}\text { Appendix D FC Power } & 103\end{array}$

$\begin{array}{lll}\text { Appendix E Uncertainty Analysis } & 108\end{array}$

E.1 Definition of the measurement process . . . . . . . . . 108

E.2 Listing of elemental error sources . . . . . . . . . . . . . . 108

E.3 Estimation of elemental errors . . . . . . . . . . . . . . . . 108

E.4 Propagation of bias and precision errors . . . . . . . . . . . 111

E.5 Calculate uncertainty . . . . . . . . . . . . . . . . . 112 


\section{List of Tables}

1 The activity of a species $[1] \ldots \ldots \ldots \ldots \ldots$

2 Grade AR-08 graphite plate properties . . . . . . . . . . . 38

3 Percent composition list of electrodes . . . . . . . . . . . . . . . 42

4 Flowing electrolyte channel specifications . . . . . . . . . . . . 44

$5 \quad$ Pumps Characteristics . . . . . . . . . . . . . . 52

6 MASTERFlex pump flow rate with respect to tubing internal diameter 52

$7 \quad$ MEA structure . . . . . . . . . . . . . . . . . . . 59

8 Effects of FE concentration on maximum power density . . . . . . 67

9 Comparison of the performance of FE-DMFC for different MEAs . . . 75

10 Mesh statistics for a $0.18 \mathrm{~mm}$ body spacing . . . . . . . . . . . 92

11 Summary of grid convergence analysis . . . . . . . . . . . . . 93

12 Summary of Variables for different Reynold numbers . . . . . . . . . 94

13 Pressure difference for the Channel length . . . . . . . . . . . 94

14 Error analysis . . . . . . . . . . . . . . . . 110 


\section{List of Figures}

1 Fuel cell principles $\ldots \ldots \ldots \ldots \ldots \ldots$

2 General polarization curve of a fuel cell . . . . . . . . . . . 5

$3 \quad$ DMFC principles . . . . . . . . . . . . . . . . . . 15

4 Methanol crossover in a DMFC . . . . . . . . . . . . . . 18

5 FE-DMFC principles .................... 20

6 Schematic of several flow channel designs . . . . . . . . . . . . 25

7 Illustration of the water uptake of Nafion . . . . . . . . 28

$8 \quad$ Nafion ${ }^{\circledR}$ structure adapted from Mauritz et al. [2] . . . . . . . . . . 28

$9 \quad$ SEM micrograph of (a) carbon paper and (b) carbon cloth [3] . . . 30

10 FE-DMFC 3D illustration . . . . . . . . . . . . . . 36

11 Current collector . . . . . . . . . . . . . . . . 37

12 A 3D Model of the Graphite plates used in this study . . . . . . . . . 39

13 Pressure distribution for $5 \mathrm{ml} / \mathrm{min} \ldots \ldots \ldots . \ldots 40$

14 Velocity contour around the bend for $5 \mathrm{ml} / \mathrm{min} \ldots \ldots 41$

15 Examples of unsuccessful FE Channel designs . . . . . . . . . . . 43

16 Microporous polyethelene spacer $(0.61 \mathrm{~mm}$ POREX $) \ldots \ldots . \ldots 44$

17 Carver Laboratory Press . . . . . . . . . . . . . . . . . . 45

18 Half cell assembly . . . . . . . . . . . . . . . . . . . . 46

19 3D Model of DMFC after assembly . . . . . . . . . . . . . 47

20 Schematic of experimental setup $\ldots \ldots \ldots \ldots \ldots$ 
21 Experimental setup . . . . . . . . . . . . . . . . 50

22 MEA configurations . . . . . . . . . . . . . . . . 60

23 Polarization and power density curves . . . . . . . . . . . 61

24 Repeatability of results . . . . . . . . . . . . . . . . . . 62

25 Effects of FE flow on the OCV . . . . . . . . . . . 64

26 Effects of FE flow on current density . . . . . . . . . . . . 64

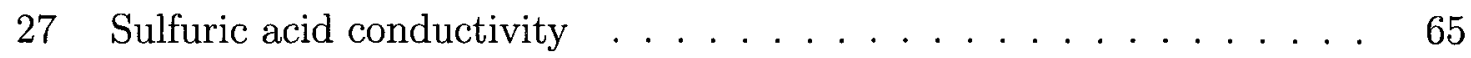

28 Effects of $\mathrm{FE}$ concentration on performance $\ldots \ldots \ldots 66$

29 Effects of FE flow rate $\ldots \ldots \ldots \ldots \ldots$

30 Effects of FE flow rate on maximum power density . . . . . . . 69

31 Effects of FE thickness on performance . . . . . . . . . 70

32 Effects of $\mathrm{FE}$ pressure on $\max$ power density $\ldots \ldots \ldots \ldots 71$

33 Effects of methanol concentration on performance . . . . . . . . . 72

34 Effects of MEA type on the performance using $0.5 \mathrm{M}$ methanol . . . 74

35 Effects of MEA type on the performance using $2 \mathrm{M}$ methanol . . . . 74

36 Effects of cell operating temperature on fuel cell performance . . . . 76

37 Effects of methanol flow rate . . . . . . . . . . . . . . 77

38 Schematic variation of pressure in duct with bend . . . . . . . . . 91

39 Meshed Channels for a body spacing $=0.18 \mathrm{~mm} \ldots \ldots$

40 Copper Plate 1 drawing . . . . . . . . . . . . . . . . . . . 97

41 Copper Plate 2 drawing $\ldots \ldots \ldots$

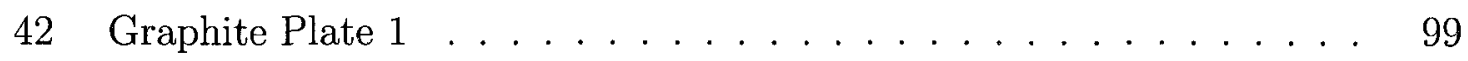

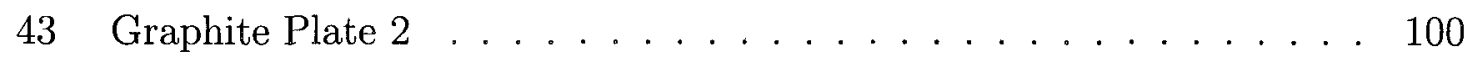

44 Temperature controller setup schematic . . . . . . . . . . . . . . 102

45 FC power . . . . . . . . . . . . . . . . . . . . . . 104

46 Creating charts . . . . . . . . . . . . . . . . 105

47 Creating custom data . . . . . . . . . . . . . 106 
48 Creating $\log$ sessions . . . . . . . . . . . . . . 106 


\section{Nomenclature}

The following acronyms, symbols and subscripts have been used throughout this thesis.

\begin{tabular}{cc}
\hline Acronym & Description \\
\hline OCV & Open Circuit Voltage \\
PEMFC & Proton exchange membrane fuel cell \\
DMFC & Direct methanol fuel cell \\
Pt & Platinum \\
Ru & Ruthenium \\
FE-DMFC & Flowing electrolyte-direct methanol fuel cell \\
GDL & Gas diffusion layer \\
FE & Flowing electrolyte \\
MEA & Membrane electrode assembly \\
\hline
\end{tabular}




\begin{tabular}{|c|c|c|}
\hline Symbol & Unit & Description \\
\hline $\mathrm{E}$ & Volts & Electromotive Force (EMF) \\
\hline $\mathrm{G}$ & Joules $[\mathrm{J}]$ & Gibbs free energy \\
\hline $\mathrm{R}$ & $J /$ mol.K & Ideal gas constant \\
\hline $\mathrm{F}$ & $c / m o l$ & Faraday's constant \\
\hline $\mathrm{T}$ & ${ }^{\circ} \mathrm{C}$ & Temperature \\
\hline$v$ & Volts & Overpotential \\
\hline$C_{i}$ & mole & Reactant concentration at the GDL-catalyst interface \\
\hline$I_{L}$ & Amps & Limiting current \\
\hline$\alpha$ & - & Charge transfer coefficient \\
\hline$A$ & $c m^{2}$ & Surface area \\
\hline $\mathrm{j}$ & $m A / \mathrm{cm}^{2}$ & Current density \\
\hline$R_{\text {ohmic }}$ & Ohms & Ohmic resistance \\
\hline$R_{\text {ionic }}$ & Ohms & Ionic resistance \\
\hline$R_{\text {elec }}$ & Ohms & Electrical resistance \\
\hline $\mathrm{B}$ & - & Bias error \\
\hline $\mathrm{S}$ & - & Random error \\
\hline
\end{tabular}




\begin{tabular}{cc} 
Subscript & Description \\
\hline \hline $\mathrm{I}$ & Current \\
$\mathrm{V}$ & Voltage \\
\hline
\end{tabular}




\section{Chapter 1}

\section{Overview}

\section{$1.1 \quad$ Introduction}

Fuel cells are electrochemical devices that convert energy released from chemical reactions into electricity. As shown in Figure 1, these chemical reactions occur between the fuel and the oxidant. In order to efficiently produce electricity from the chemical reaction, the fuel and oxygen reactants are spatially separated by an electrolyte, and therefore, the reaction is split into two electrochemical half reactions. For example, in a hydrogen fuel cell, the following half reactions take place:

$$
\begin{array}{cc}
\mathrm{H}_{2} \rightarrow 2 \mathrm{H}^{+}+2 e^{-} & \text {(Anode reaction) } \\
\frac{1}{2} \mathrm{O}_{2}+2 \mathrm{H}^{+}+2 e^{-} \rightarrow \mathrm{H}_{2} \mathrm{O} & \text { (Cathode reaction) }
\end{array}
$$

An electric current is formed when the electrons moving from the fuel species are forced to flow through an external circuit to get to the oxidant species in order to complete the reaction. The performance of the fuel cell is defined by the voltage output from the cell at a given current density or vice versa [1].

The basic components of a fuel cell include two electrodes where the fuel and oxidizing agents are distributed and the chemical reactions occur. Examples of 


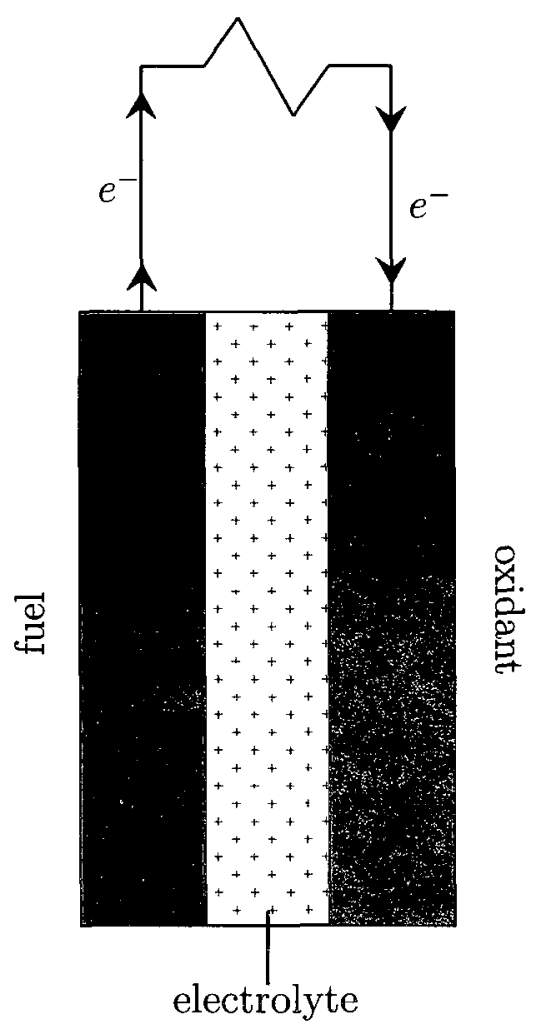

Figure 1: Fuel cell principles

typical fuels include hydrogen, methanol, methane, carbon monoxide, natural gas, and inorganic reducing agents such as hydrogen sulfide and hydrazine. Air, pure oxygen, hydrogen peroxide, and chlorine are examples of common oxidizing agents [4]. An electrolyte separates the two electrodes and it is made of a material that allows ions to flow but is extremely resistant to electrons and for this reason, it is used to separate the two reactants. The electrolyte material can be either solid or liquid. Examples of liquid electrolyte used in fuel cells include aqueous solutions of acids, alkalies, and salts, as well as, molten salts. Most fuel cells, however, use solid electrolytes, which are either ionically conducting organic polymers or inorganic oxide compounds [4].

Fuel cells can also be categorized as indirect, direct or regenerative. In an "indirect" fuel cell, the fuel is processed and converted to hydrogen before it is introduced to the cell. A reformer fuel cell is an example of an indirect fuel cell that uses organic 
fuels. Another example is a biochemical fuel cell where the biochemical substance is decomposed by an enzyme to produce hydrogen. The direct fuel cell has a simpler system since the fuel is not pre-processed and the fuel is fed directly to the fuel cell. In the types of fuel cells just mentioned, the products of the cell are discarded. In a regenerative system, however, the products of the reactions are regenerated and circulated back to the cell [5].

\subsection{Theory}

The potential difference between the electrodes is the thermodynamic value of voltage, which has been termed the cell's electromotive force or EMF (E). It can also be obtained from the potential difference between the fuel and oxidant electrodes [6]. The electromotive force is the highest voltage that could be obtained by the cell if there were no losses, which corresponds to the Gibbs free energy $(G)$ of the current producing reaction. Equation 1 shows how Gibbs free energy and reversible voltage are related.

$$
\Delta G=-n F E
$$

where $n$ is the number of exchange electrons per mole of reactant, $F$ is Faraday's constant, and $\mathrm{E}$ is the reversible voltage or $\mathrm{EMF}$.

Given a general chemical reaction such as the following reaction where A and B react to produce $C$ and $D$ with respective stoichiometric coefficient of $j, k$, $m$ and $n$, the Gibbs free energy can be calculated using Equation 2.

$$
\begin{gathered}
j A+k B \rightarrow m C+n D \\
G_{0}=\Delta H_{0}-T \Delta S_{0}
\end{gathered}
$$


where $G_{0}$ is the Gibbs free energy at standard pressure and temperature $\left(25^{\circ} \mathrm{C}\right.$, $1 \mathrm{~atm}), T$ is temperature and $\Delta H_{0}$ and $\Delta S_{0}$ are shown by Equations 3 and 4 , respectively.

$$
\begin{aligned}
\Delta H_{0} & =\left[m \Delta H_{0}(C)+n \Delta H_{0}(D)\right]-\left[j \Delta H_{0}(A)+k \Delta H_{0}(B)\right] \\
\Delta S_{0} & =\left[m \Delta S_{0}(C)+n \Delta S_{0}(D)\right]-\left[j \Delta S_{0}(A)+k \Delta S_{0}(B)\right]
\end{aligned}
$$

Therefore, the variation of the reversible cell voltage with chemical activity (chemical composition, concentration, etc.) is given by the Nernst Equation:

$$
E=E_{0}-\frac{R T}{n F} \ln \frac{a_{C}^{m} a_{D}^{n}}{a_{A}^{j} a_{B}^{k}}
$$

where $E_{0}$ is the standard-state reversible voltage, $R$ is the ideal gas constant $(8.314 \mathrm{~J} / \mathrm{mol} \mathrm{K})$ and $a$ is the activity of the species. The activity of species depends on its chemical nature. Table 1 summarizes the activity of a species based on the chemical composition. In this table, $p_{i}$ and $p_{0}$ represent the partial pressure of the gas and the standard state pressure $(1 \mathrm{~atm})$, respectively. The term $\gamma_{i}$ is an activity coefficient describing the departure from ideality $\left(0<\gamma_{i}<1\right)$. Similarly, $c_{i}$ is the molar concentration of the species and $c_{0}$ represents the standard-state concentration $(1 \mathrm{M})[1]$.

The Nernst Equation accounts for the pressure effects on the reversible cell voltage but not the temperature effects. In order to account for the temperature effects where the cell temperature is not the same as the standard temperature, $E_{0}$ has to be replaced by $E_{T}$, shown by Equation 6 [1]. This equation could be used to estimate the open circuit voltage as well. 
Table 1: The activity of a species [1]

\begin{tabular}{|c|c|}
\hline Composition & Activity formula \\
\hline Ideal gas & $a_{\imath}=\frac{p_{\imath}}{p_{0}}$ \\
\hline Non-ideal gas & $a_{\imath}=\gamma_{\imath}\left(\frac{p_{\imath}}{p_{0}}\right)$ \\
\hline Dilute ideal solution & $a_{\imath}=\frac{c_{\imath}}{c_{0}}$ \\
\hline Non-ideal solution & $a_{\imath}=\gamma_{\imath}\left(\frac{c_{\imath}}{c_{0}}\right)$ \\
\hline Pure component & $a_{\imath}=1$ \\
\hline
\end{tabular}

$$
E_{T}=E_{0}+\frac{\Delta S}{n F}\left(T-T_{0}\right)
$$

Figure 2 shows a polarization curve of a typical fuel cell, where the voltage is shown as a function of the current density. As explained above, the EMF is the highest voltage that a cell could obtain without any losses.

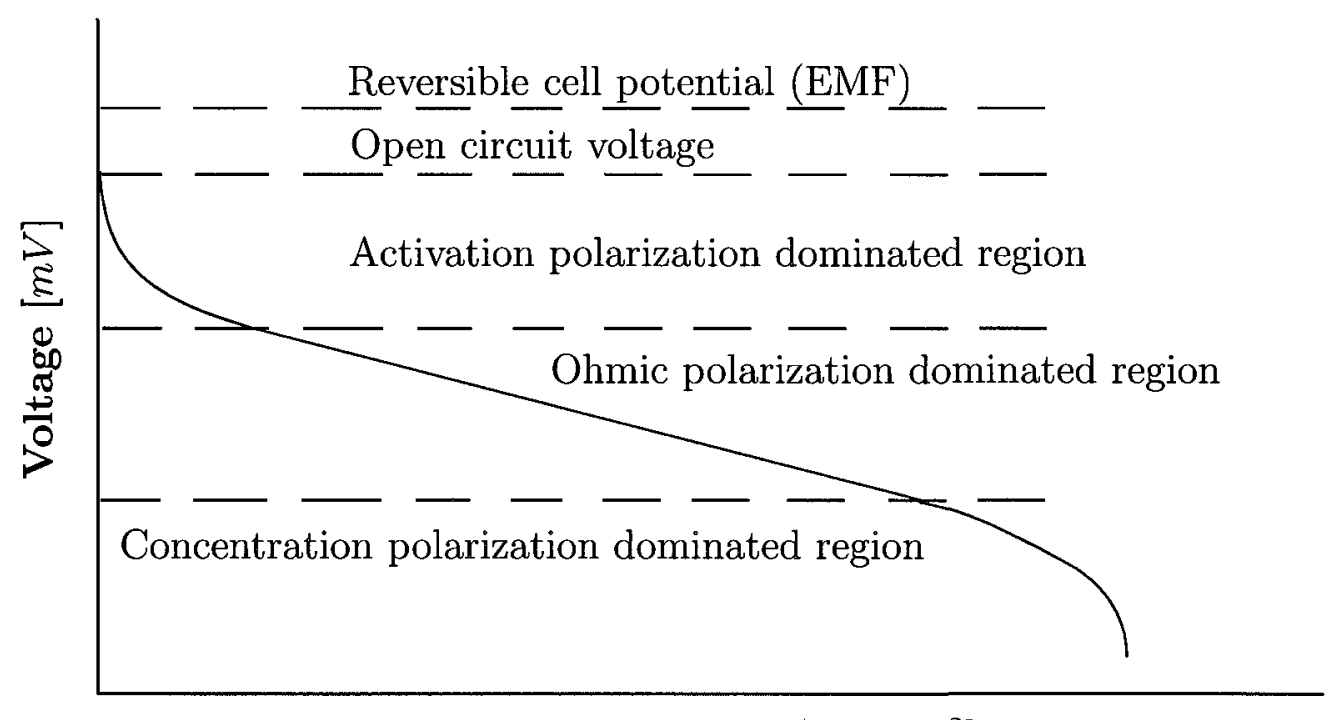

Current density $\left[\mathrm{mA} / \mathrm{cm}^{2}\right]$

Figure 2: General polarization curve of a fuel cell 
The open circuit voltage (OCV) of a fuel cell is the practical value of the voltage of an idle cell [4]. However, electrical energy is obtained from a fuel cell only when current is drawn. If the current is large, the cell voltage falls fairly rapidly due to various nonequilibrium effects such as the internal resistance of the cell itself [7]. These voltage losses are referred to as the overpotential, $v$. Contributing to these voltage losses are activation losses $\left(v_{a c t}\right)$ at the anode and cathode catalyst, ohmic losses in the electrolyte $\left(v_{\text {ohmic }}\right)$, and mass transfer limitations at the electrodes $\left(v_{\text {conc }}\right)$ [8]. The effects of these losses on the polarization of the fuel cell are shown in Figure 2. Equation 7 shows the irreversible voltage losses $\left(V_{\text {irrev }}\right)$ while Equation 8 shows the operating voltage of the cell $(V(i))$.

$$
\begin{gathered}
V_{\text {irrev }}=v_{\text {act }}+v_{\text {ohmic }}+v_{\text {conc }} \\
V(i)=E-V_{\text {irrev }}
\end{gathered}
$$

Activation polarization is the voltage overpotential required to overcome the activation energy of the electrochemical reaction on the catalytic surface, which dominates the losses at low current density, and also measures the catalyst effectiveness at a given temperature. The fuel, the catalyst, and the electrolyte must all make contact that makes it a complex, multiphase problem [7]. Equation 9 is called the Tafel equation, which calculates the activation losses.

$$
v_{a c t}=\frac{R T}{\alpha F} \ln \left(\frac{i}{i_{0}}\right)
$$

where $\alpha$ is the charge transfer coefficient, $i$ is the current density and $i_{0}$ is the reaction exchange current density. The reaction exchange current density $\left(i_{0}\right)$ measures the electrode activity for a reaction at equilibrium. Therefore, the equation for the anode 
and cathode activation overpotential can be represented by:

$$
v_{\text {act-anode }}+v_{\text {act-cathode }}=\left.\frac{R T}{n \alpha F} \ln \left(\frac{i}{i_{0}}\right)\right|_{\text {anode }}+\left.\frac{R T}{n \alpha F} \ln \left(\frac{i}{i_{0}}\right)\right|_{\text {cathode }}
$$

Resistance of conductors to charge flow results in a loss in cell voltage. This is referred to as the ohmic polarization. The electrical resistance of the electrolyte, the catalyst layer, the gas diffusion layer, reactant distributor plates, interface contacts and terminal connections contributes to the ohmic polarization. The voltage loss due to the ohmic polarization is called ohmic loss, which includes the electronic and ionic contributions. According to Ohm's law, the ohmic polarization can be described by Equations 11 and 12. It should be noted that the ionic transport is more difficult than electronic charge transport. Therefore, $R_{\text {ionic }}$ dominates the voltage reduction [7].

$$
\begin{gathered}
v_{\text {ohmic }}=I R_{\text {ohmic }}=I\left(R_{\text {elec }}+R_{\text {ionic }}\right) \\
v_{\text {ohmic }}=j\left(A_{\text {cell }} R_{\text {ohmic }}\right)
\end{gathered}
$$

In order to produce electricity, fuel cells should continuously be supplied with fuel and oxidant. The performance of the fuel cell is determined by the reactant and product concentration within the catalyst. It is therefore important to have proper removal of the products to avoid performance loss due to lack of reactants. In addition, optimizing the mass transport of the fuel cell electrodes and flow structures results in minimization of concentration loss [7]. The mass transport in the reactant distributor channels is dominated by convection due to their dimensions, which are usually in millimeters. The pore sizes of the gas diffusion layer (GDL) and the catalyst layer is usually between 4 to 10 microns. Therefore, the mass transport is dominated by diffusion in the GDL. The concentration losses in a fuel cell could be 
calculated using Equations 13 or 14 [6].

$$
v_{\text {conc }}=\frac{R T}{n F} \ln \frac{C_{0}}{C_{i}}
$$

where $C_{i}$ is the reactant concentration at the GDL/catalyst interface and $C_{0}$ is the original concentration of the reactant.

$$
v_{\text {conc }}=\frac{R T}{n F} \ln \left(\frac{I_{L}}{I_{L}-1}\right)
$$

where $I_{L}$ represents the limiting current.

\subsection{Characteristics of fuel cells}

Fuel cells have numerous advantageous characteristics such as their efficiency, simplicity, high reliability, low emissions, silent operation and flexibility. The energy efficiency of fuel cells is higher than heat engines at the design load since the energy conversion efficiency of a fuel cell is directly proportional to the cell voltage. Therefore, power output and cell current density decrease with reduced loading, which would result in cell potential increase. However, the efficiency of heat engines decreases due to increased mechanical and heat losses at partial load. Furthermore, due to their higher efficiency, fuel cells produce less chemicals, carbon dioxide, and thermal emissions [9]. Also, fuel cells have extremely low pollutant emissions since no harmful chemicals such as nitrogen oxides $\left(N O_{x}\right)$ or sulphure oxides $\left(S O_{x}\right)$ are formed during the process $[9]$.

In addition, fuel cells have an excellent and fast transient load response making them flexible for several applications. The fuel cell's response to load changes is only limited to the response in the reactant flow, which is very fast. Since fuel cells have 
no mechanical moving components (except in the reactant flow auxiliary equipment), they are quiet and highly reliable, resulting in low operation and maintenance costs [9].

The main disadvantage with fuel cells is the high cost associated with their fabrication and production. An additional problem with fuel cells is the availability of fuel and storage. For example, hydrogen is used as the fuel in most fuel cells, however, hydrogen is not widely available and is difficult to store.

\subsection{Application of fuel cells}

Fuel cells produce electric power on demand that makes them suitable for a variety of applications ranging from a few watts to megawatts. Fuel cells have high efficiency, no pollutant emissions and quiet operations, which makes them desirable for power generation applications [9]. Fuel cell applications can be categorized into the following sectors: portable, transportation and stationary.

\subsubsection{Portable sector}

Compact electronic devices such as laptops, cameras, video recorders and auxiliary power units are portable devices that need a certain amount of power to operate over a specific length of time. As these devices become more complex and offer more functions, more power is required. Unlike the rechargeable batteries that need to be recharged using an external power supply for a period of time, fuel cells have the advantage of being instantaneously recharged when they are provided with fresh fuel. The DC power generated by fuel cells could be used directly in these portable devices and there is no need to convert AC to DC power [9]. Often portable fuel cells are used by the military since they can operate over a longer period of time and they are also quiet and have low heat signatures [7]. 


\subsubsection{Transportation sector}

The automotive sector generally uses fossil fuels in order to power vehicles. However, fossil fuels are limited and they produce a significant amount of pollutants. Fuel cell vehicles using hydrogen as fuel have zero emissions and they are also more fuel efficient [7]. Since the early 1990's, most of the major car manufacturing companies have built at least one prototype of a vehicle that can operate with fuel cells [10]. Ballard Power Systems also has produced fuel cells that were used to operate buses in Vancouver and Chicago [9]. As well, since 1964, fuel cells have been successfully used in space shuttles, such as Gemini and Apollo. In fact, the first practical application of fuel cells was in space programs [9]. Finally fuel cells could also be used in forklifts, boats, planes, trains, etc.

\subsubsection{Stationary sector}

Stationary fuel cells may be divided into two categories; large power (more than $10 \mathrm{~kW}$ ) and small power (less than $10 \mathrm{~kW}$ ). Large power fuel cells are intended to generate grid power, and small power fuel cells are typically used to produce a larger amount of energy for powering a house or a business [4]. The waste heat of fuel cells can be used for heating space or water [4,9]. In addition, fuel cells can also be more reliable than other commercial generators [7]. Fuel cells could also be used as backup power in case of sudden loss of grid power for applications where power interruptions could be costly or dangerous [4].

\subsection{Types of fuel cell}

Fuel cells can operate at various temperature ranges, and can be made up of different materials and have performance characteristics. When considering the type 
of electrolyte used in fuel cells, there are 5 major types. These are discussed below [1].

1. Phosphoric acid fuel cell (PAFC)

A PAFC has two porous electrodes coated with platinum catalyst. A thin silicon carbide $(\mathrm{SiC})$ matrix is placed between the electrodes where the liquid electrolyte phosphoric acid $\left(\mathrm{H}_{3} \mathrm{PO}_{4}\right)$ is contained. Hydrogen is considered as the fuel and air or oxygen as the oxidant. This type of fuel cell operates above $42^{\circ} \mathrm{C}$ since pure phosphoric acid hardens at this temperature. The optimum operating temperature is between 180 to $210^{\circ} \mathrm{C}$. The $\mathrm{SiC}$ matrix minimizes reactant gas crossover and provides mechanical strength to the electrolyte and separates the two electrodes.

2. Solid-oxide fuel cell (SOFC)

The most popular electrolyte material used in this type of fuel cell is yttriastabilized zirconia (YSZ), which is an oxygen ion conductor. The anode and the cathode should be able to stand various environments; therefore, they are made of different materials. Nickel-YSZ cement is used for the anode to withstand highly corrosive and high temperature environments. The material used for the cathode must be able to resist highly oxidizing, high temperature environments. Typical cathode materials include strontium-doped lanthanum manganite, lanthanum-strontium ferrite, lanthanum-strontium cobaltite, and lanthanumstrontium cobaltite ferrite. This type of fuel cell operates between 600 to $1000^{\circ} \mathrm{C}$.

3. Alkaline fuel cell (AFC)

Liquid potassium hydroxide $(\mathrm{KOH})$ electrolyte is used in this type of fuel cell where $\mathrm{OH}^{-}$is conducted from the cathode to the anode. The amount of water produced at the anode is twice of the amount of water that is consumed at the cathode. The excess water should be removed from the system, otherwise it will reduce the performance of the fuel cell. The operating temperature of the fuel cell depends on the concentration of $\mathrm{KOH}$ used in the electrolyte $\left(60-250^{\circ} \mathrm{C}\right)$. Pure hydrogen 
and pure oxygen are used as the fuel and oxidant respectively, since the presence of any $\mathrm{CO}_{2}$ degrades the $\mathrm{KOH}$ electrolyte.

4. Molten carbonate fuel cell (MCFC)

A molten mixture of alkali carbonates, $\mathrm{Li}_{2} \mathrm{CO}_{3}$ and $\mathrm{K}_{2} \mathrm{CO}_{3}$ are used as the electrolyte, which are restrained in a $\mathrm{LiAlO}_{2}$ matrix. The charge carrier in this type of fuel cell is therefore, $\mathrm{CO}_{3}^{2-}$. The $\mathrm{CO}_{2}$ produced at the anode is fed to a burner, and the resulting mixture of steam and $\mathrm{CO}_{2}$ is mixed with fresh air and supplied to the cathode. It operates at about $650^{\circ} \mathrm{C}$, which enables a higher efficiency and the usage flexibility of more types of fuel and less expensive catalysts. Hydrogen, simple hydrocarbons and simple alcohols can be used as fuel.

5. Polymer electrolyte membrane fuel cell (PEMFC)

The electrolyte used in a PEMFC is a polymer electrolyte membrane (PEM), which is a conductor of protons. Platinum-based catalysts are loaded on either side of the electrolyte and it is supported by porous carbon electrode support material. It operates below $90^{\circ} \mathrm{C}$. Hydrogen and oxygen or air are used as the fuel and oxidant, respectively. A direct methanol fuel cell is a subcategory of PEMFC. Direct methanol fuel cell (DMFC) could be categorized as a type of PEMFC since it uses the same polymer electrolyte membrane, but uses methanol as fuel instead of hydrogen.

\subsection{Direct methanol fuel cells}

E. Muller was the first person to explore the methanol electro-oxidation process in 1922. However, it was not until the early 1950's that the concept of methanol fuel cells were explored by Kordesch and Marko, and by Pavela [11]. In the recent decades, extensive research has been conducted on the direct electrochemical oxidation of 
alcohol and hydrocarbon fuels. The direct methanol fuel cell (DMFC) has a potential to offer higher power density than current lithium-ion rechargeable batteries since methanol specific energy is $21.6 \mathrm{MJ} / \mathrm{kg}$ while theoretically lithium ion polymer offers $2.16 \mathrm{MJ} / \mathrm{kg}$ of energy, which makes it suitable for portable electronic devices $[8,12]$. The operating temperatures of liquid fed DMFCs are typically between the room temperature and $100^{\circ} \mathrm{C}$, and they are expected to have about $40 \%$ efficiency [7].

\subsubsection{Methanol as a fuel}

Methanol is a liquid hydrocarbon with a boiling temperature of $64.7^{\circ} \mathrm{C}$ at atmospheric pressure. Methanol has a high volumetric energy density (approximately $18 \mathrm{MJ} / \mathrm{L}$ ) whereas this value is $9.36 \mathrm{MJ} / \mathrm{L}$ for liquid hydrogen. The high energy density along with easy handling, refueling and storage are the major advantages of methanol for mobile applications [9].

Another characteristic that makes methanol a suitable fuel is its hydrogen-tocarbon ratio, which is the highest among alcohols. Therefore, the least amount of carbon dioxide is generated while the highest energy is generated. Methanol is also miscible in water, which means that different concentrations of methanol can be fed to the fuel cell system [13].

Methanol fuel can either be supplied directly or indirectly. In a DMFC, the fuel is supplied directly to the cell for electro-oxidation of methanol. In an indirect methanol fuel cell, however, methanol is first fed to an onboard reformer to be converted to a hydrogen-rich reformate gas mixture and then supplied to the cell [9]. 


\subsubsection{DMFC reactions}

Figure 3 shows a schematic of a regular DMFC. An aqueous methanol solution flows in the channels of a distributor plate on the anode side and diffuses through the gas diffusion layer (GDL) made of carbon paper or carbon cloth. The GDL is loaded with Platinum - Ruthenium (Pt-Ru) catalyst and the following reaction occurs. The anode potential is shown by $E_{\text {anode }}^{o}$.

$$
\mathrm{CH}_{3} \mathrm{OH}+\mathrm{H}_{2} \mathrm{O} \rightarrow \mathrm{CO}_{2}+6 \mathrm{H}^{+}+6 e^{-} \quad E_{\text {anode }}^{o}=0.02 \mathrm{~V}[4]
$$

The PEM which is a good electrical insulator allows the protons to pass while electrons are forced through an external circuit to arrive at the cathode [9]. The carbon dioxide produced, emerges from the GDL as bubbles and is then removed by the flowing methanol solution.

On the cathode side, air is fed to the distributor channels and is diffused through another GDL, which is coated with platinum catalyst. As can be seen from the chemical reaction below, the oxygen in the air reacts with the electrons and protons to form water. The anode potential is shown by $E_{\text {cathode }}^{o}$.

$$
\frac{3}{2} \mathrm{O}_{2}+6 \mathrm{H}^{+}+6 e^{-} \rightarrow 3 \mathrm{H}_{2} \mathrm{O} \quad E_{\text {cathode }}^{o}=1.23 \mathrm{~V}[4]
$$

The overall cell reaction and potential is formed from a combination of the two reactions shown below.

$$
\mathrm{CH}_{3} \mathrm{OH}+\frac{3}{2} \mathrm{O}_{2} \rightarrow 2 \mathrm{H}_{2} \mathrm{O}+\mathrm{CO}_{2} \quad \mathrm{EMF}=\mathrm{E}_{\text {cell }}^{o}=1.21 \mathrm{~V}[4]
$$

\subsubsection{Methanol intermediate steps}

Methanol is the most electro-active organic fuel for fuel cells. The electro-oxidation reaction of methanol to carbon dioxide releases six electrons. Even at the presence 


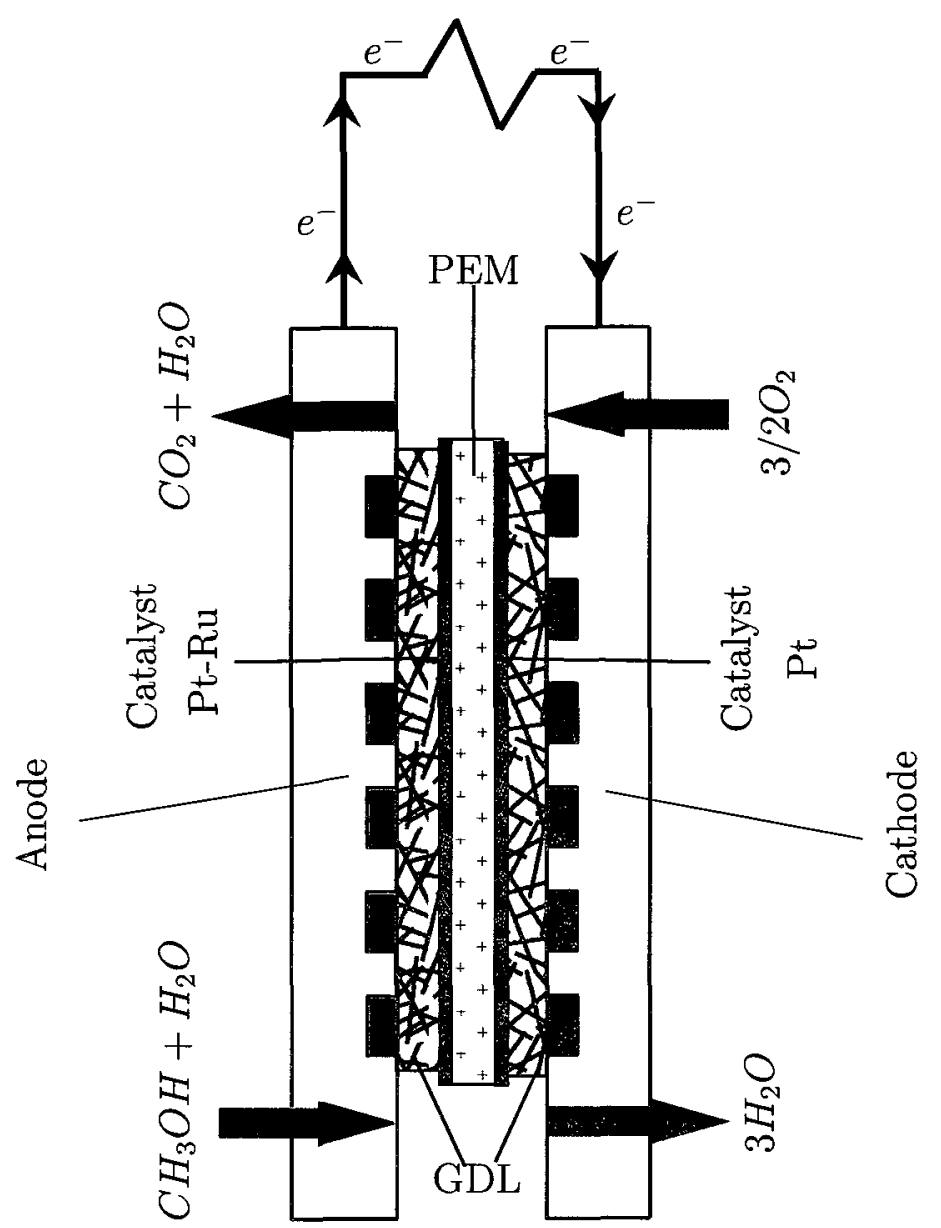

Figure 3: DMFC principles

of the best possible electro-catalysts, production of partial oxidation materials such as formaldehyde, formic acid, and methyl formate occurs due to the slow kinetics of this reaction. The following reactions show a general pathway leading to partial or complete oxidization of methanol on Pt-Ru catalysts:

$$
\begin{gathered}
\mathrm{CH}_{3} \mathrm{OH}+\mathrm{Pt} \rightarrow \mathrm{Pt}-\mathrm{CH}_{2} \mathrm{OH}+\mathrm{H}^{+}+1 e^{-} \\
P t-\mathrm{CH}_{2} \mathrm{OH}+\mathrm{Pt} \rightarrow \mathrm{Pt}-\mathrm{CHOH}+\mathrm{H}^{+}+1 e^{-} \\
\mathrm{Pt}-\mathrm{CHOH}+\mathrm{Pt} \rightarrow \mathrm{Pt}-\mathrm{CHO}+\mathrm{H}^{+}+1 e^{-} \\
\mathrm{Pt}-\mathrm{CHO} \rightarrow \mathrm{Pt}-\mathrm{CO}+\mathrm{H}^{+}+1 e^{-}
\end{gathered}
$$


Due to the presence of $\mathrm{Ru}$ catalyst, water discharging occurs at low anodic overpotentials and results in formation of $\mathrm{Ru}-\mathrm{OH}$ species at the catalyst surface.

$$
\begin{gathered}
R u+\mathrm{H}_{2} \mathrm{O} \rightarrow \mathrm{RuOH}+\mathrm{H}^{+}+1 e^{-} \\
R u O H+\mathrm{PtCO} \rightarrow \mathrm{Pt}-\mathrm{Ru}+\mathrm{CO}_{2}+H^{+}+1 e^{-}
\end{gathered}
$$

On a lower catalyst such as $\mathrm{Pt}$, formation of some formic acid and formaldehyde will occur. Based on different studies conducted, the main poisoning species is identified to be strongly adsorbed species, which will block the electrode sites for further intermediate formation during methanol oxidation. The most important step then is to form $\mathrm{CHO}$ species, which facilitates the overall reaction. Increasing the operation temperature will significantly improve the DMFC performance. This will occur due to the faster carbon monoxide (CO) removal from the catalyst surface [12].

\subsubsection{Characteristics of DMFC}

As explained in Section 1.6.1, methanol is directly fed to the DMFC, and therefore eliminates the need for a complex reformer unit in the system. Also, diluted methanol is used, which provides the cell with a large amount of water. Hence, DMFCs avoid complex humidification and thermal management problems associated with PEMFCs [9].

Although rechargeable batteries require hours for charging a depleted power pack, a DMFC can have its fuel replaced in minutes. Direct methanol fuel cells potential for refueling makes it an attractive development in portable electronic devices market [12].

Current DMFCs power densities have been reported to be double of current lithiumion rechargeable batteries with an overall efficiency of about $20-25 \%$. However, there are critical factors that prevent DMFCs from reaching their maximum efficiency [8]. 
One of the challenges DMFCs face today is the slow reaction kinetics of methanol. As explained in Section 1.6.3, slow reaction kinetics at the anode is due to the multistep fuel oxidation process, which results in anodic overpotentials [14]. The other problem is the intermediate hydrocarbon species produced by methanol oxidation that poison the catalysts. Finally, one of the most significant problems with DMFCs is methanol crossing over to the cathode, which reduces the overall performance of the fuel cell [7,15-18]. Figure 4 illustrates the methanol moving through the Nafion ${ }^{\circledR}$ and poisoning the cathode. This latter concept is of great interest and covered in the subsequent section.

\section{Methanol crossover}

In any fuel cell, it is important to separate the anode and the cathode to prevent fuel from directly contacting the cathode and oxidizing thereon. Therefore, the proton exchange membrane must separate the fuel and the oxidant. The known membranes are good for proton exchange, but not very efficient as fuel separators. The fuel crossover occurs when fuel (prior to oxidization) goes through the membranes and contacts the cathode. This not only causes loss of fuel, but also results in a short circuit in the cell since the electrons resulting from the oxidation reaction do not follow the current path between the electrodes. Furthermore, fuel crossover causes structural changes on the cathode surface, poisoning of the reduction catalyst by fuel oxidation products.

Electro-osmotic drag, permeation and diffusion are the three mechanisms that facilitate methanol crossover. In Figure 4, methanol passes through the membrane and reacts directly with oxygen. As a result of this reaction, electrons are produced and consumed at the cathode and therefore, reduce the current produced by the fuel cell. It should also be noted that since there is no $\mathrm{Ru}$ on the cathode, the $C O$ 
produced by this reaction poisons the Pt catalyst.

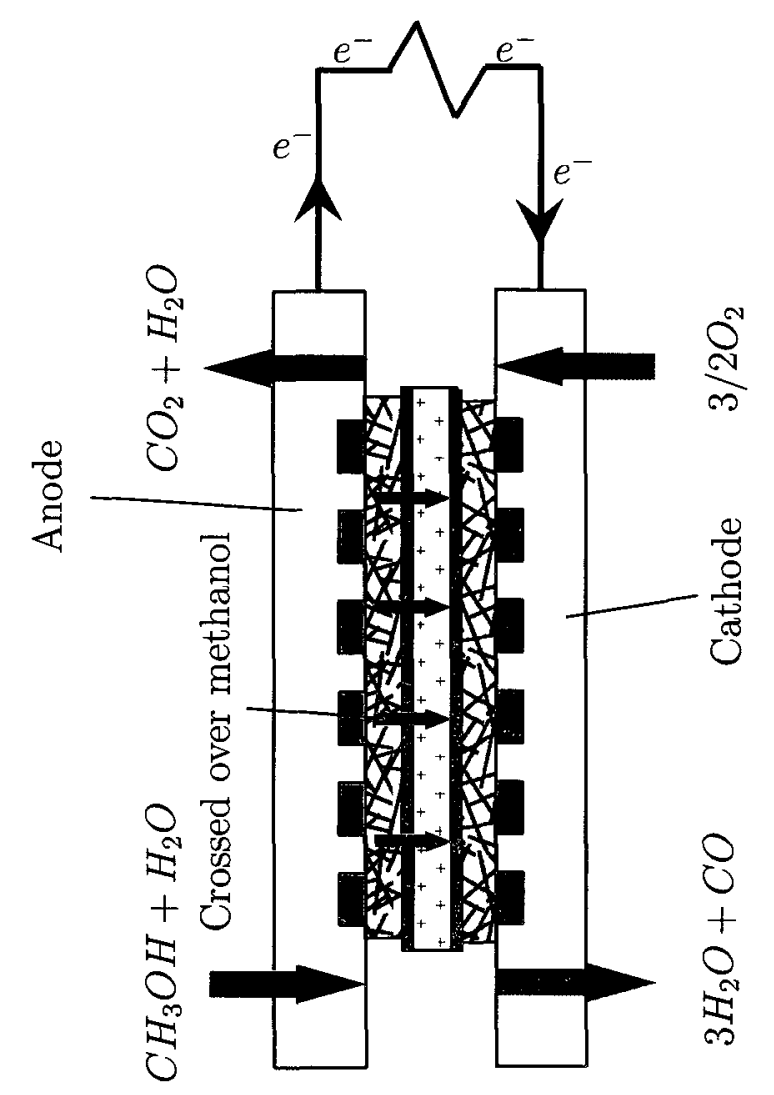

Figure 4: Methanol crossover in a DMFC

The electro-osmotic drag happens as a result of transfer of hydrated protons from the anode to the cathode. Water and methanol molecules are attached to the protons and transfer to the cathode as a result of protons migrating through the membrane [17]. The concentration gradient of methanol in the cathode drives the diffusion of methanol through the membrane [7].

Minimizing crossover can be achieved by control of the anode fuel feed concentration and flow rate, as well as, the utilization of effective methanol oxidizing anode catalysts. Over the past decade, there has been much interest to minimize methanol crossover in DMFCs. Kordesch et al. [19] proposed a novel concept of introducing a flowing 
electrolyte such as weak sulfuric acid $\left(\mathrm{H}_{2} \mathrm{SO}_{4}\right)$ that circulates between the electrodes of the cell and removes any un-oxidized fuel that crosses over before it reaches the cathode. The flowing electrolyte also allows better thermal and water control of the fuel cell system.

\subsection{Flowing electrolyte-direct methanol fuel cell}

A direct methanol fuel cell with the circulating electrolyte concept was first suggested by Kordesch et al. in 2001 [20]. In this design, the electrolyte diffused through a porous spacer located between the two electrodes and removes any crossed over (c/o) methanol from the cell before it reaches the cathode. A schematic of a single cell flowing electrolyte-direct methanol fuel cell (FE-DMFC) is shown in Figure 5. Other advantages of FE-DMFCs include simple water and heat management and the possibility of removing reaction by-products such as aldehyde residues, carboxylic acids, etc. It should be noted that the system is more complex due to various added components [21].

As shown in Figure 5, the fuel enters the cell through the anode inlet and diffuses through the porous anode. After the oxidization reaction at the catalyst layer, any unreacted fuel along with products will exit from the outlet. The protons will go through the PEM while the electrons will be conducted through an electrical connection from the anode to the cathode and through an external load. The fluid electrolyte will remove any unreacted fuel or product that passes through the PEM along with the protons; however being acidic, the electrolyte will let the protons cross to the cathode side. The oxidant is provided to the cathode through the inlet and after the reduction reaction, the products are expelled through the outlet [19]. 


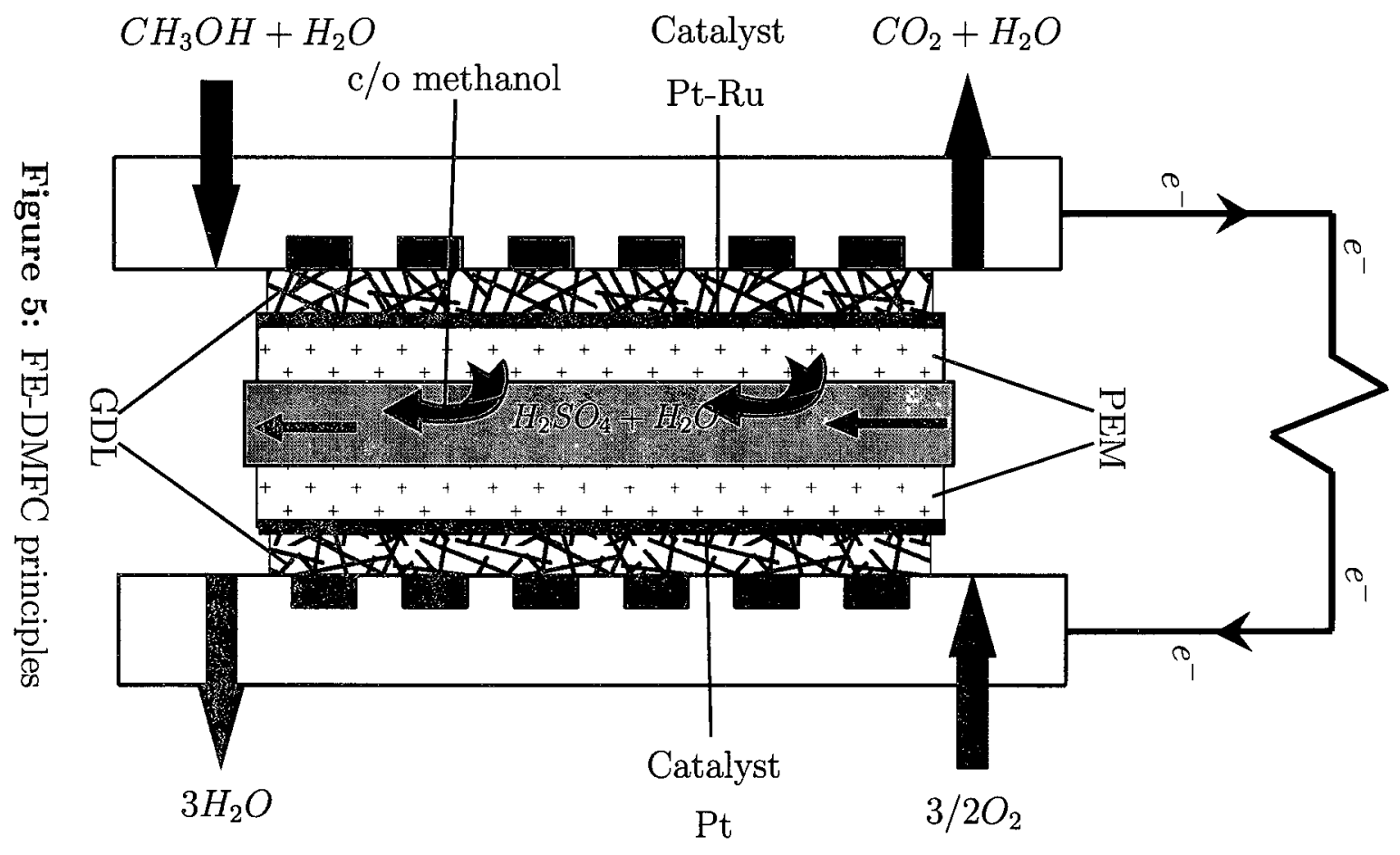


One of the shortcomings of FE-DMFC is the management of the flowing electrolyte itself. The flowing electrolyte circulation systems can be divided into four categories:

1. Non-circulating flowing electrolyte: fresh electrolyte is used and the contaminated electrolyte is stored in a container; the used electrolyte will be retrieved and recycled in separate industrial facilities.

2. Circulating flowing electrolyte: this method circulates the electrolyte repeatedly and requires electrolyte change from time to time.

3. Circulating electrolyte with in-situ purification: in this method, the methanol is separated from the electrolyte in the device; this method is not viable due to compactness reasons.

4. Circulating electrolyte going through an additional DMFC: in this method, the electrolyte waste goes through a DMFC in order for the methanol inside the electrolyte to be consumed.

\subsection{Objectives}

The purpose of this study is to design and develop a single cell flowing electrolytedirect methanol fuel cell in order to verify the effects of introducing a flowing electrolyte on the performance of the fuel cell. Also, a parametric study will be conducted on several operating conditions such as methanol and sulfuric acid concentration, flowing electrolyte flow rate and pressure, as well as, Nafion and flowing electrolyte thickness.

Chapter 2 includes a review of literature on fuel cell components, assembly and fabrication methods and previous acidic flowing electrolyte fuel cell developments. Chapter 3 explains the design of the flowing electrolyte-direct methanol fuel cell along 
with the list of components used. Chapter 4 discusses the experimental setup design and the test station. Chapter 5 presents the experimental results and the discussion, and finally Chapter 6 includes the conclusions and future work. 


\section{Chapter 2}

\section{Literature Review}

There are numerous factors that affect the performance of the direct methanol fuel cells (DMFC), such as channel design, catalyst loading, electrode fabrication, electrolyte material, etc. A literature review is presented in this chapter for all of the major components that influence the performance of a DMFC.

\subsection{Reactant distributor plates}

The main purpose of the reactant distributor plate is to evenly distribute fuel and oxidant to the cells, remove the products of the reactions away and to collect the electrons that are generated at the catalyst layer [7]. Plate material and the flow field design are the two of the most important factors that affect the performance of the fuel cell.

\subsubsection{Plate material}

The material for this component is chosen based on several factors, such as chemical compatibility, resistance to corrosion, electronic conductivity, gas diffusivity/impermeability, manufacturability, material strength, thermal conductivity, and cost. Resin-impregnated graphite is the most commonly used material in Polymer 
electrolyte membrane fuel cells (PEMFCs) and DMFCs. Graphite material is often used for plates in low temperature fuel cells since it is highly conductive, chemically inert and resistive to corrosion. However, it is expensive and costly to manufacture [7]. Aluminum, steel, titanium, and nickel plates are also used in low temperature fuel cells. In addition, metallic plates can be manufactured in thin layers. However, dissolved metal ions can diffuse into the electrolyte, which would lower the ionic conductivity of the cell. Therefore, graphite, gold, silver, palladium, platinum, carbon and conductive polymer coatings are often used to prevent the metal from corroding [7].

\subsubsection{Flow field design}

As mentioned earlier, mass transfer has a significant effect on the performance of the fuel cell. Flow fields that are engraved on the graphite plate are responsible for a mass transfer of the reactants to the catalysts. Beside mass transport, the flow fields play a significant role on the characteristics of membrane hydration and cathode poisoning [22]. They should also be designed to minimize pressure drop in order to reduce the pumping power. The most popular channel designs are parallel, serpentine, parallel serpentine, inter-digitated or pin-type flow fields [7]. A schematic of these channel designs are shown in Figure 6.

In 2000, Airco et al. investigated effects of serpentine versus interdigitated flow field on the performance of a DMFC. They observed a higher OCV and a lower voltage drop in the activation controlled region in the presence of the serpentine channel. The interdigitated design, however, resulted in significantly higher cell voltages in the mass transport region, which is due to the enhance mass transport properties. On the other hand, larger methanol crossover was observed for the interdigitated design compared to the serpentine channel [22]. 


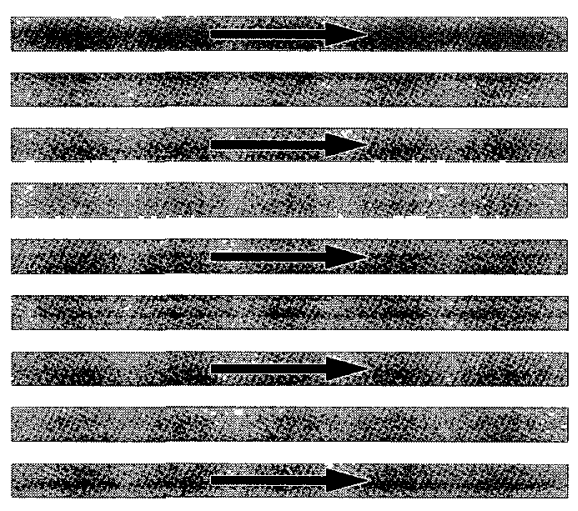

Parallel

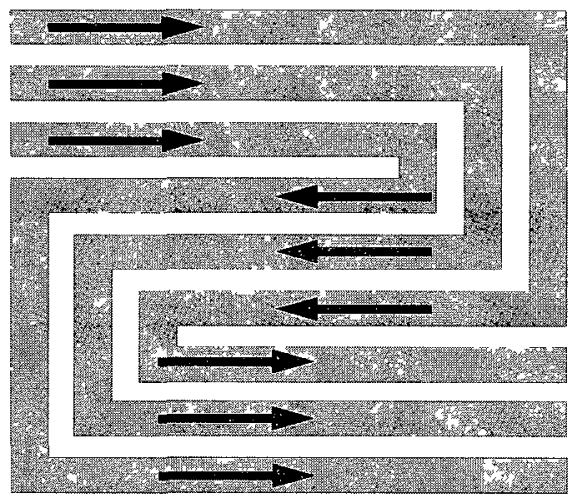

Parallel serpentine

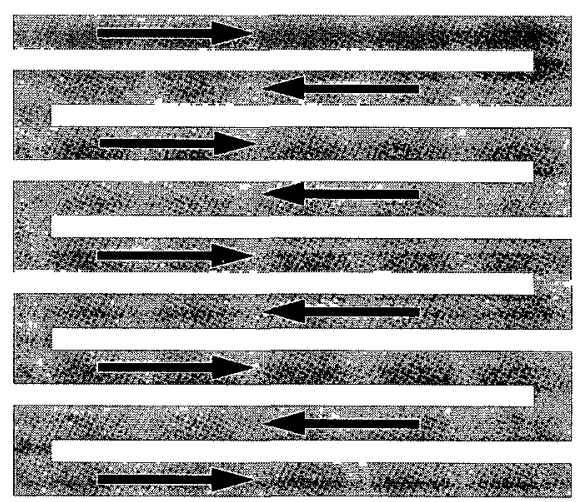

Single serpentine

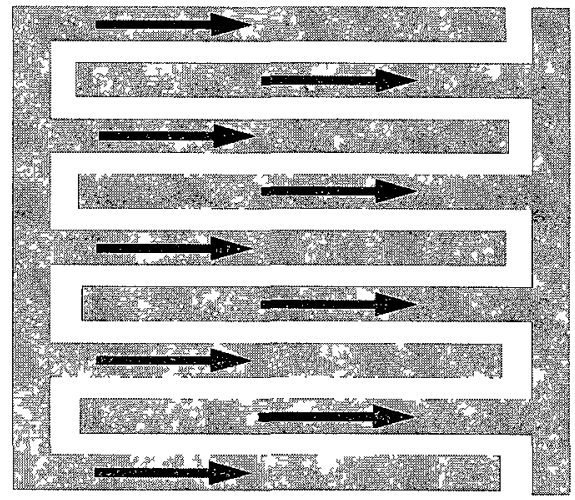

Inter-digitated

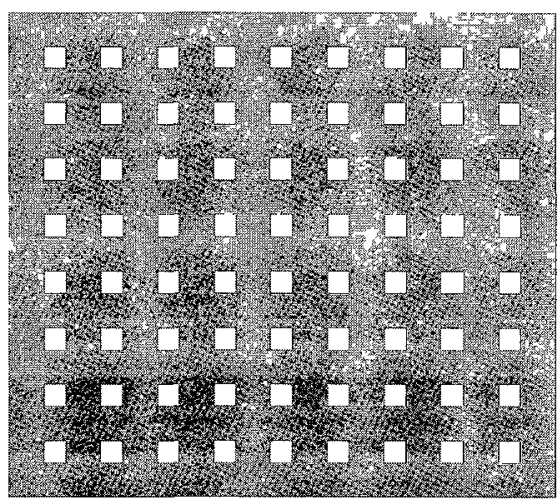

Pin-type

Figure 6: Schematic of several flow channel designs 
In 2009, Kim et al. conducted a 3-dimensional CFD simulation to compare the velocity and pressure distribution for parallel, serpentine and zigzag flow fields. This study showed that despite the serpentine's higher flow resistance, they provide more uniform velocity distribution resulting in better performance. The zigzag design showed similar results to the serpentine design and the parallel channel was found to have non-uniform velocity distribution in the anode channels including a stagnant zone and reverse flow in the upper part to the exit [23]. These findings are in agreement with Yang et al. who experimented on serpentine and parallel flow fields for the anode of a DMFC in 2005 and found that fuel cells with the serpentine channel tend to perform better. They also discovered that for the parallel flow field design, at high current densities and low methanol solution flow rates, gas bubbles formed and blocked the flow channels [24]. Finally, this study showed that an open ratio of approximately $50 \%$ resulted in the best cell performance at moderate and high methanol solution flow rates, and at low flow rates, a larger open ratio yielded a higher power density at higher current densities [24].

A year later, Oliveira et al. tested a number of serpentine configurations such as a single serpentine, multi-serpentine and an original design mixed parallel and serpentine. They found that when the fuel cell operates at lower temperatures and with low methanol concentrations, the mixed design at the anode provides better performance due to lower pressure drop which prevents the formation of stagnant flow areas. At higher operating temperatures, however, all of the designs have similar performance. They also found that for high values of methanol concentration, the multi-serpentine at the anode results in the best performance. Both of the serpentine designs showed good performance on the cathode side, which is due to adequate water removal [25]. 


\subsection{Membrane electrode assembly}

A membrane electrode assembly (MEA) consists of a membrane, gas diffusion layers, and catalyst layers. The catalyst can be either applied on the membrane or the gas diffusion layer. For both methods, the catalyst is sandwiched between the GDL and the membrane. The following sections contain details on each of the components and the fabrication process of the MEA.

\subsubsection{Membrane}

A direct methanol fuel cell membrane should be stable at high operation temperatures and have minimal methanol crossover, as well as, high ionic conductivity and high chemical and mechanical durability [26,27]. There are four main types of membrane that are typically used in DMFCs. Nafion ${ }^{\circledR}$ is the most commercially available membrane for this type of fuel cell [28]. Other categories are non-Nafion fluorinated, composite fluorinated and non-fluorinated membranes [29]. In this study, Nafion ${ }^{\circledR}$ will be used.

Nafion ${ }^{\circledR}$ ionomers were developed and are produced by DuPont ${ }^{\mathrm{TM}}$. Nafion ${ }^{\circledR}$ membranes are non-reinforced films, which are formed based on copolymerization of a perfluorinated vinyl ether monomer with tetrafluoroethylene. The structure of Nafion ${ }^{\circledR}$ is shown in Figure 8 [2]. Nafion ${ }^{\circledR}$ contains a hydrophobic fluorocarbon backbone and perfluoroether side chains that terminate in sulfonic acid $\left(\mathrm{SO}_{3} \mathrm{H}\right)$. The hydrolyzed form of sulfonic acid $\left(\mathrm{SO}_{3}-\mathrm{H}_{3} \mathrm{O}^{+}\right)$allows for effective proton transport across the membrane $[8,29]$. In order to solvate the acid groups, the dry membrane absorbs water. As shown in Figure 7, the water clusters eventually connect to form channels that serve as the proton transport pathways. Therefore, it can be concluded that the proton transfer in Nafion ${ }^{\circledR}$ is strongly depended on the water content of the 
membrane.

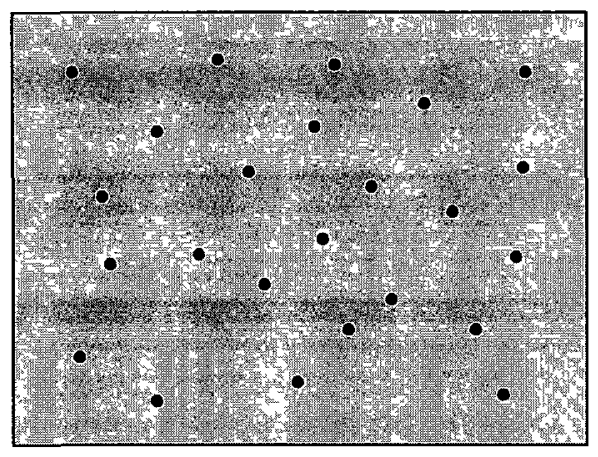

Dry Nafion

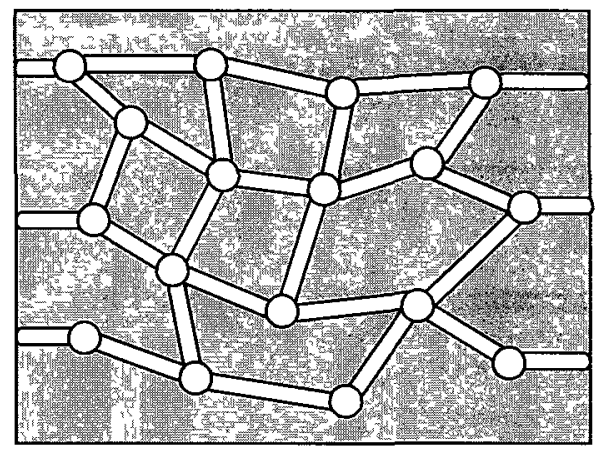

Hydrated Nafion

Figure 7: Illustration of the water uptake of Nafion

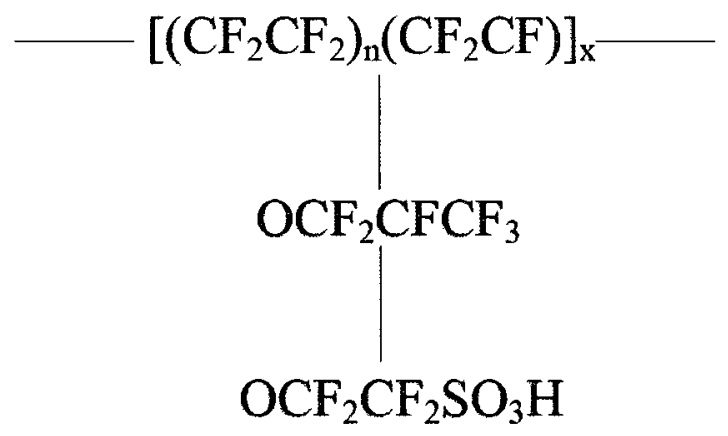

Figure 8: Nafion ${ }^{\circledR}$ structure adapted from Mauritz et al. [2]

Nafion ${ }^{\circledR}$ N117, N115, NRE-212 and NRE-211 are the most commonly used membranes. The designation 11 from 117 refers to a film having 1100 equivalent weight (EW) and the 7 refers to a nominal thickness of 0.007 inch $(177.8 \mu \mathrm{m})$ [2]. The EW corresponds to the number of grams of dry Nafion ${ }^{\circledR}$ per mole of sulfonic acid groups when the material is in the acid form [2]. Nafion ${ }^{\circledR}$ is relatively durable, has high ionic conductivity and thermal and chemical stability due to its hydrophobic polytetrafluoroethylene (PTFE) backbone. The main disadvantages of Nafion ${ }^{\circledR}$ are high methanol and ruthenium crossover, high cost, low temperature limit and high humidification requirements [29]. 
In 1998, Jung et al. measured the concentration of methanol in the drain water coming from the cathode, and found that the weight percentage of methanol in the water from the cathode outlet was three times higher for the MEA using Nafion ${ }^{\circledR}$ 112 than when Nafion ${ }^{\circledR} 117$ was used [30]. In 1996, Narayanan et al. observed that increasing membrane thickness from $127 \mu \mathrm{m}$ to $431.8 \mu \mathrm{m}$ (0.005 to 0.017 inch) causes the crossover to reduce by approximately 40-50\% [31]. Later in 2004, Ling et al. confirmed these results by showing the methanol crossover behaviour for Nafion ${ }^{\circledR}$ 117, 1135, 1035 and 112 using cyclic voltammetry and concluded that increasing thickness and equivalent weight of the Nafion ${ }^{\circledR}$ will result in decreasing methanol crossover [18]. In 2009, Oliveira et al. also investigated the effect of membrane thickness on the performance by testing Nafion ${ }^{\circledR} 212$ and 117 . They found that the DMFCs, which use a thicker membrane have better performance due to lower methanol crossover [14]. Narayanan et al. (1996) also reported that an increase in the EW of the membrane resulted in a small reduction in voltage, increase in the internal resistance and also a reduction of methanol crossover [31].

In 2003, Villaluenga et al. investigated the permeability of Nafion ${ }^{\circledR}$ to watermethanol solution and found that permeation rates through the membrane increased with methanol concentration [16]. In 1996, Kauranen et al. and Narayanan et al. reported that the $\mathrm{Nafion}^{\circledR}$ permeability to methanol increases with temperature [15,31]. Hallinan et al. also measured the diffusion and sorption of methanol and water in Nafion ${ }^{\circledR}$ using Time-Resolved Fourier Transform InfraredAttenuated Total Reflectance Spectroscopy methanol and found that the methanol sorption in Nafion ${ }^{\circledR}$ is the main contributing factor to the increase in methanol flux and not the increase in methanol diffusion [32]. 


\subsubsection{Gas diffusion layer}

Carbon cloth or carbon paper can be used as the GDL (sometimes referred to as the backing layer in the literature). These layers are typically $100-300 \mu m$ thick [33]. The tortuosity and the surface properties of the GDL, such as wettability and roughness, are two important parameters that affect the performance of the fuel cell due to mass transport and bubble/droplet management, respectively. Carbon cloth is more porous and less tortuous than carbon paper [14]. As shown in Figure 9 , the carbon paper fibers are randomly structured while the carbon fibers are woven in the carbon cloth.

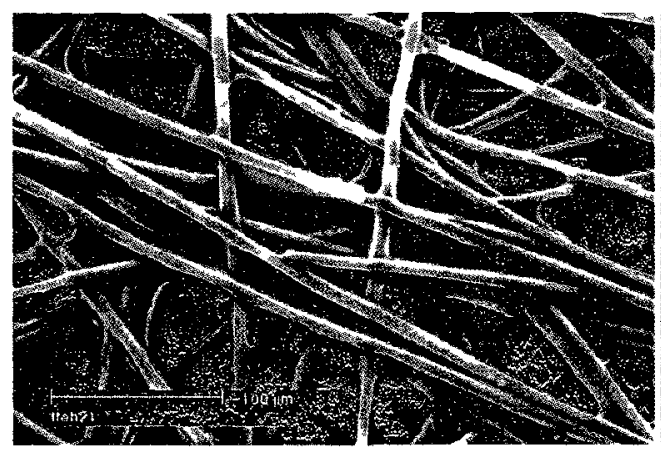

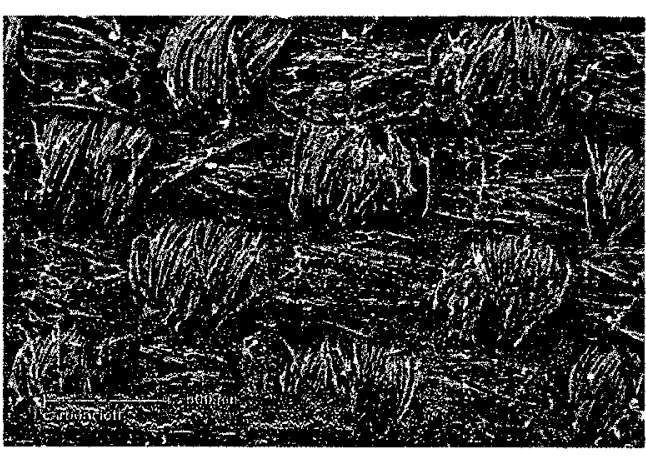

Figure 9: SEM micrograph of (a) carbon paper and (b) carbon cloth [3]

Oliveira et al. found that using the carbon paper in the anode resulted in better performance when compared to carbon cloth. Due to less porosity, the carbon paper limits the amount of methanol that reaches the membrane. The carbon paper is also thinner which results in less mass transport resistance [14]. Their study also showed that carbon cloth performs best on the cathode side due to its increased capacity to remove the liquid water and also better facilitation of oxygen transport. The tortuosity of the carbon cloth is lower and imposes a lower transport resistance. In 2004, Argyropoulos et al. also compared the performance of carbon paper and cloth on the anode of a DMFC and concluded that the carbon cloth performs better as a 
result of better gas removal properties [34]. The findings of Oedegaard et al., in a study that was conducted in 1999, also confirms these results. They also observed unstable current due to gas bubbles blocking the methanol access to the catalyst layer [35].

\subsubsection{Fabrication method}

There are three main methods that are used to prepare MEAs [36]. In the first method, the catalysts are applied to the GDL and then hot pressed onto each side of the membrane. This method has the advantage that the catalyst loading can be adjusted very precisely by simply weighing the gas diffusion layer before and after the coating process [37]. Another method is called the "decal" method where the catalyst layers are spread on Teflon supports (using a Nafion containing ink) and then transferred to the membrane by hot pressing [38]. The Teflon support is then peeled away and the catalyst coated membrane is sandwiched between the porous carbon supports. In the third method, the catalyst ink can be painted or sprayed directly onto the membrane. This is called catalyst coated membrane or CCM [39]. In this study, the first of the three GDL-based method has been adopted.

\section{Catalyst application methods}

As mentioned in the previous section, the catalyst can either be applied to the GDL or the membrane. In 2003, Mehta et al. identified and summarized several methods of catalyst application for each of them. The catalyst can be applied to the GDL by spreading, spraying, powder deposition, ionomer impregnation or electro-deposition, and the CCM can be done by either impregnation reduction, evaporative deposition, dry spraying, decaling, painting or a novel fabrication method that was suggested by Matsubayashi et al. $[33,40]$. 


\section{Hot pressing}

Hot pressing is a simple way of creating good interfacial contact between the electrodes and the membrane. However, this procedure can change the porosity and the performance of the MEA [41]. It can also cause the dehydration of the Nafion ${ }^{\circledR}$ membrane, which may lead to an irreversible performance loss of the MEA [42]. It should be noted, however, that the pore sizes in the electrode and therefore the mass transport rates, decrease with hot pressing, which in turn increase the time required for the MEA activation [43]. The hot pressing temperature is usually about $130^{\circ} \mathrm{C}$, which is slightly above the glass transition temperature of Nafion ${ }^{\circledR}$ membrane. The hot pressing pressure ranges from about 2 to $34 \mathrm{MPa}$, and the hot pressing time varies from 30 to $300 \mathrm{~s}[43]$.

In 2006, Zhang et al. investigated the effects of hot pressing temperature, pressure and time separately. Hot pressing temperature of $125^{\circ} \mathrm{C}$ and $135^{\circ} \mathrm{C}$ were tested, and it was found that although the higher temperature MEA reaches the optimum performance more slowly, it had lower cell resistance and therefore better cell performance. Their analysis for hot pressing pressure effects revealed that the porosity of the electrode and the MEA thickness decreased after hot pressing, which restricted the mass transport and shortened the mass transport pathway, respectively. Therefore, the diffusion resistance and the mass transport rates of the MEA hot pressed with moderate hot pressing pressure are optimized and provided the optimum performance. Investigation on hot pressing time has shown that the porosity and mass transport rates of the electrodes decrease and the diffusion resistances increase when the MEAs are hot pressed for a longer period. It was also shown, however, that short hot pressing periods could result in an inadequate connection between the electrodes and the membrane, which increases the internal resistance [43]. 
In 1992, Wilson et al. reported that MEAs prepared by the CCM method exhibited only slightly inferior performances if they were not hot pressed [39]. Song et al. (2004) investigated effects of hot pressing on the performance of the fuel cell using electrodes where catalysts were applied to the GDL. They found that the pressure during hot pressing influenced the performance the most and achieved the best performances without employing a pressing procedure. They reported that the pressure exerted during cell assembly was sufficient to provide good contact between the electrodes and the membrane [36].

\section{$2.3 \quad$ Flowing electrolyte}

In 2000, Kordesch et al. conducted their first FE-DMFC test. No membrane was used. They used 0.5 M sulphuric acid as the electrolyte and pumped it through the system using a peristaltic pump and at an exchange rate of 4 times a minute. The experiment was conducted at ambient temperature. Diluted methanol with a $10 \mathrm{M}$ concentration was used at the anode and pure oxygen at the cathode. The experiment was divided into 2 phases. In Phase 1, the electrolyte was circulated where they observed that the open circuit voltage $(\mathrm{OCV})$ reached $0.8 \mathrm{~V}$ and remained stable although the methanol could easily go through due to no PEM usage. In Phase 2, the electrolyte circulation was stopped and it was observed that the OCV decreased by the effect of methanol crossover [20].

Within the range of the current literature search, no experimental reports on Kordesch's design were found. In 2005, Choban et al. developed a membraneless laminar flow-based micro fuel cell, where they used diluted methanol as the fuel and dissolved oxygen in sulfuric acid. In this design the two liquid streams and the liquidliquid interface provided the ionic conductance of the fuel cell [44]. Jayashree et al. 
(2010) also experimented on this concept with $1 \mathrm{M}$ formic acid in $0.5 \mathrm{M}$ sulfuric acid at the anode. They found that low flow rates resulted in high fuel utilization efficiencies, while high flow rates ensured better cell performance [45].

In another study in 2007, Jayashree et al. tested the liquid electrolyte concept in a membraneless microfluidic hydrogen fuel cell at room temperature. They found that the flowing electrolyte minimized the issues in a PEMFC such as cathode flooding, anode dry out, and electrolyte dehydration at high temperature [46].

Holinger et al. tested the same concept on a micro scale laminar flow fuel cell [47]. They performed their experiments with $1 \mathrm{M}$ sulfuric acid, $1 \mathrm{M}$ methanol and pure oxygen at $80^{\circ} \mathrm{C}$. The fuel cell's highest performance was obtained using a nanoporous material. This combination gave them maximum OCV of $0.64 \mathrm{~V}$ and power density of $70 \mathrm{~mW} / \mathrm{cm}^{2}[47]$.

In this study a FE-DMFC was designed based on Kordesch's concepts. The design and the materials used in the fabrication of this fuel cell is discussed in the next chapter. 


\section{Chapter 3}

\section{Flowing Electrolyte-Direct Methanol Fuel Cell Design}

In the previous chapter, the components that make up a DMFC were identified and discussed. In this chapter, the design of a FE-DMFC and all the materials used in fabricating a single cell, as well as, the fabrication process will be explained.

\subsection{Single cell components}

There are several important components for the operation of a fuel cell such as electrolyte, electrodes, reactant distributor channels, current collector, etc. Several materials and designs were tested as gaskets and for the flowing electrolyte (FE) channel in order to find the best performing fuel cell. Since sulfuric acid was used as the flowing electrolyte in this study, all components used were also resistant to sulfuric acid. Figure 10 illustrates an exploded view of the single cell FE-DMFC used for this study. A description of each component follows. 


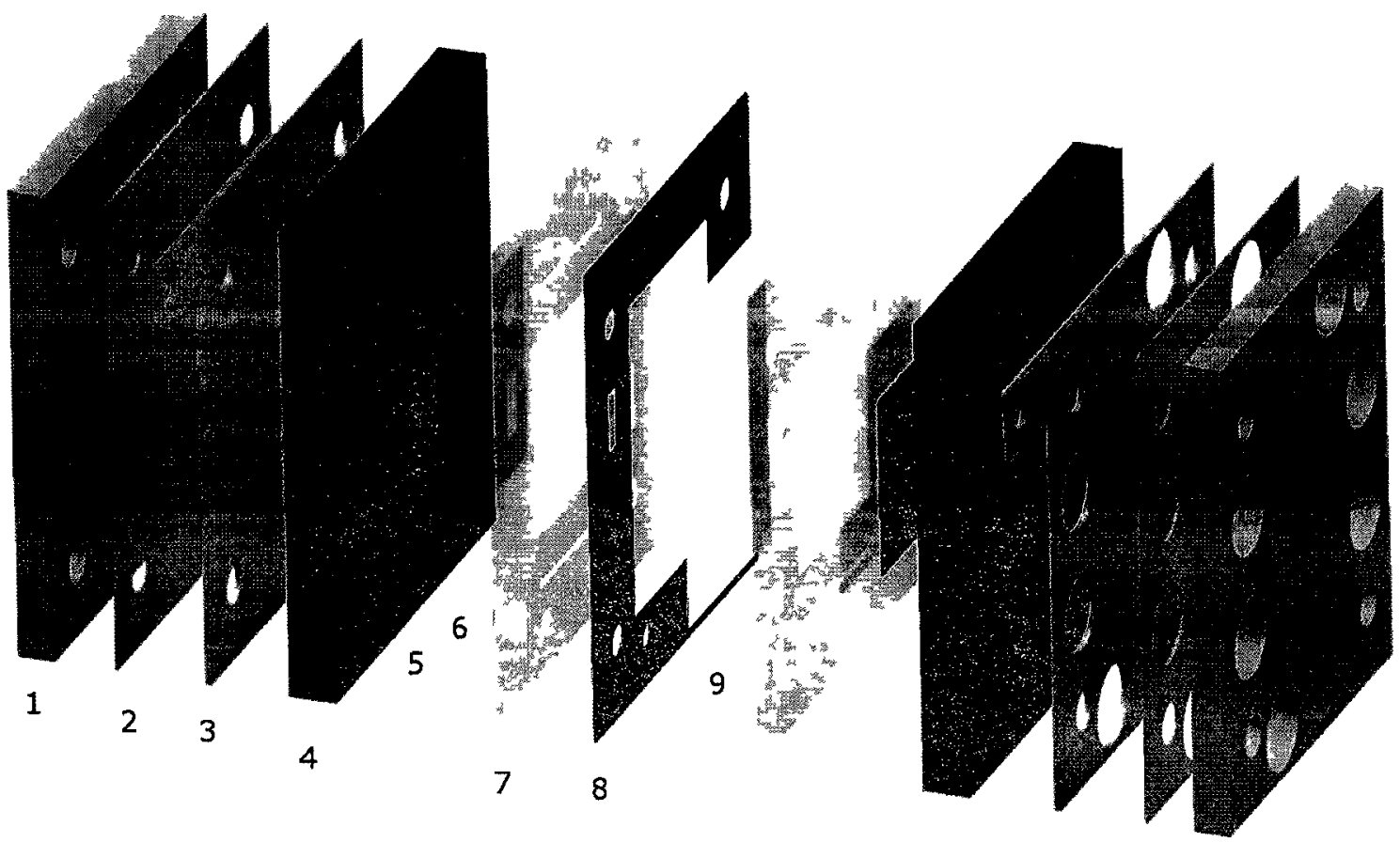

1: End plate

2: Teflon sheets

3: Current collector

4. Reactant distributor plate

5. Electrode

6 Membrane

7. PTFE tape

8. Viton gasket

9: Flowing electrolyte channel

Figure 10: FE-DMFC 3D illustration 


\subsubsection{End plates}

The outer most component on both sides of the fuel cell are the end plates. For this study, stainless steel end plates ( $13 \mathrm{~mm}$ thick) were used to protect the structure of the fuel cell and provide an even compression on the inner components of the cell. Heaters were also attached to these plates.

\subsubsection{Polytetrafluoroethylene (PTFE) sheets}

The second component shown in Figure 10 is the PTFE sheet that was used between the end plate and the current collector in order to electrically insulate the end plate and prevent a short circuit of the electrons.

\subsubsection{Current collector}

As mentioned previously, the current collector is one of the key components of a fuel cell and collects the electrons from the graphite plates and act as the poles of the fuel cell. Copper plates (1.25 mm thick) with 1 micron gold plating were used as current collectors for this study (see Figure 11). Appendix B contains the drawings of these

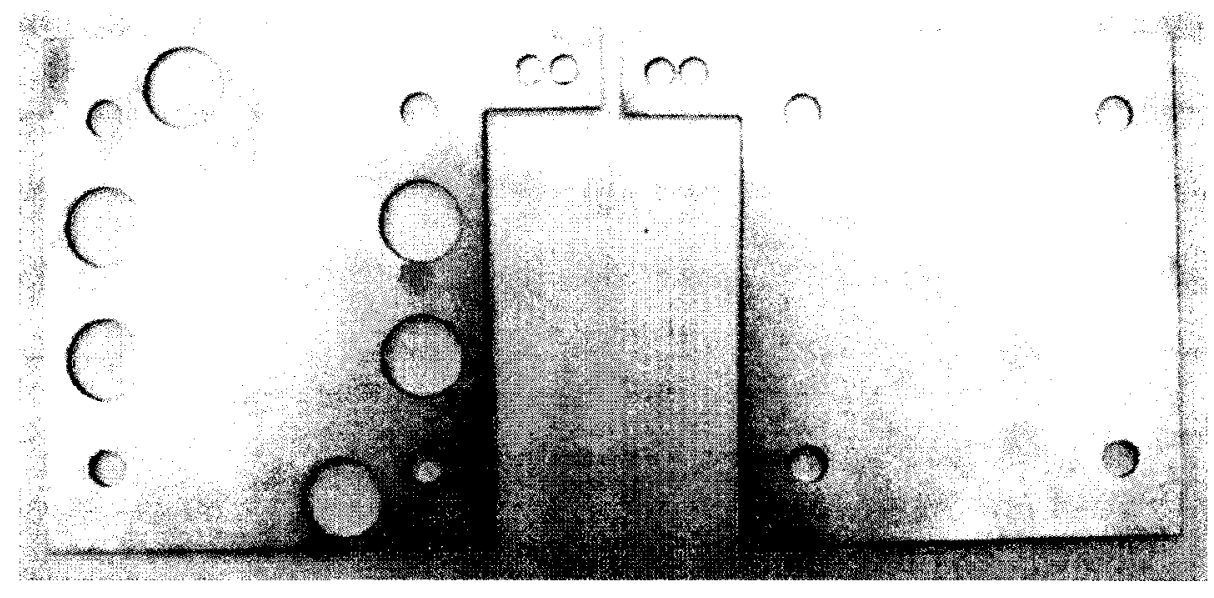

Figure 11: Current collector 
plates. It should be noted that the end plates also follow the same dimensions, except for the thickness.

\subsubsection{Reactant distributor plate}

For the fuel cell under study, grade AR-08 graphite was used for the reactant distributor plate. The physical, mechanical and electrical properties of these plates are indicated in Table 2 [48]. The reactant distribution channels were machined in these graphite plates and parallel serpentine channels were used for the methanol and air passages in the fuel cell. This arrangement can be seen in Figure 12. The serpentine channel area is $25 \mathrm{~cm}^{2}$. The design is based on the design by Pure Energy Vision Inc. in Richmond Hill, Ontario.

Table 2: Grade AR-08 graphite plate properties

\begin{tabular}{|c|c|}
\hline \multicolumn{2}{|c|}{ Physical Properties } \\
\hline Apparent Bulk Density & $1.80 \mathrm{~g} / \mathrm{cc}$ \\
\hline Particle Size & $11.9 \mu \mathrm{m}$ \\
\hline \multicolumn{2}{|c|}{ Mechanical Properties } \\
\hline Hardness, Shore D & 65 \\
\hline Flexural Strength & $51.7 \mathrm{MPa}$ \\
\hline Compressive Strength & $114 \mathrm{MPa}$ \\
\hline \multicolumn{2}{|c|}{ Electrical Properties } \\
\hline Electrical Resistivity & $0.00124 \mathrm{ohm}-\mathrm{cm}$ \\
\hline
\end{tabular}

A Pro Engineer drawing of this component can be found in Appendix B. Figure 12 shows a 3D model of the graphite plates used in this study. The plate on the right has six openings that facilitates the movement of the methanol, air, and electrolyte. Air flows in this plate from top to bottom as the labels Air $_{i n}$ and Air $r_{\text {out }}$ indicate. The electrolyte enters the plate from the top and flows in the cell 


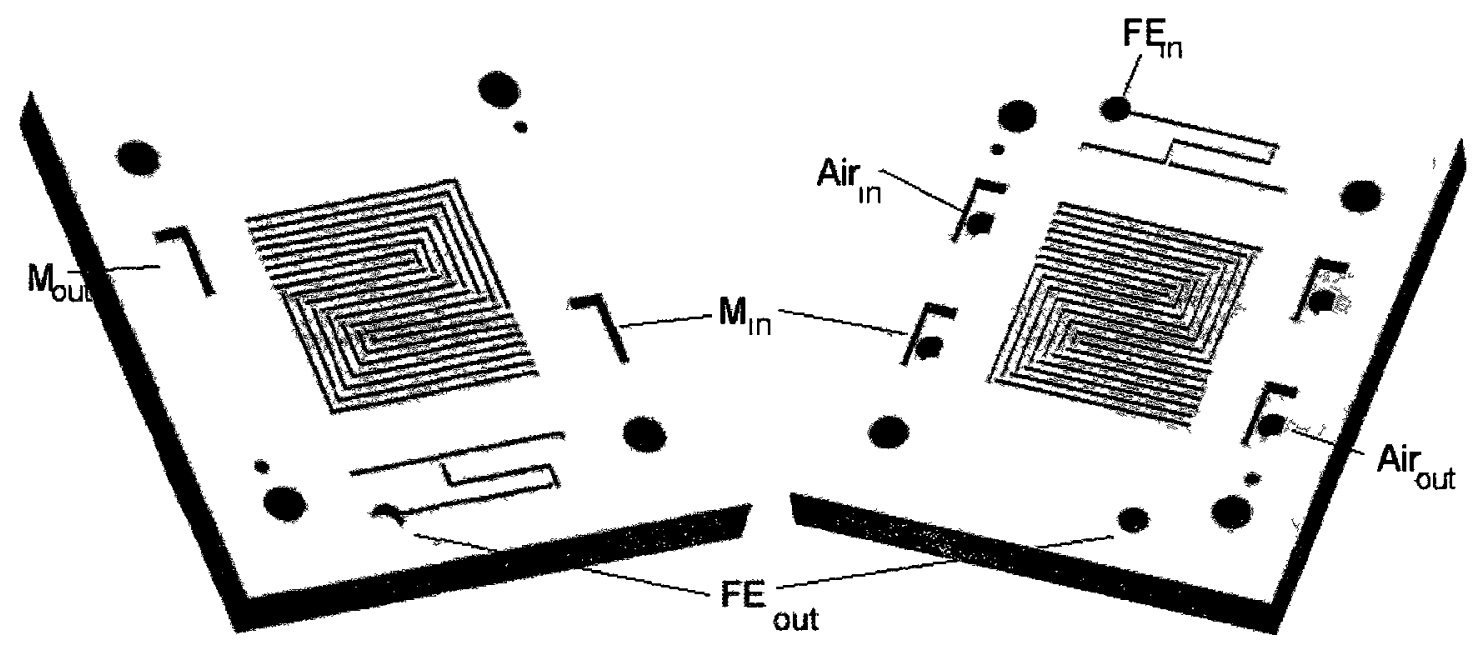

Figure 12: A 3D Model of the Graphite plates used in this study

before it accumulates and exits on the bottom. The plate on the left is the methanol plate. As $M_{\imath n}$ (methanol inlet) and $M_{\text {out }}$ (methanol outlet) are indicated on the plates, the diluted methanol flows from the bottom of the channels to the top of the plate in order to help $\mathrm{CO}_{2}$ removal from the system. The air, flowing electrolyte, and methanol flows are separated and sealed accordingly by membranes and gaskets, respectively, following the design shown in Figure 10.

\section{CFD analysis of laminar flow in the channels}

In order to estimate the pressure drop in the reactant distributor channels and to size the pumps and the system components, a laminar single phase CFD analysis was conducted for methanol flow. Details of the simulation are explained in Appendix A. For this analysis, it was assumed that the properties of methanol solution are similar to water, and the outlet boundary condition was set to atmospheric pressure. It should be noted that in a fuel cell, one of the channels sides is a porous material, but in this simulation, smooth wall conditions were assumed for all of the four sides. Figures 13 and 14 show the pressure and velocity distribution for $5 \mathrm{ml} / \mathrm{min}$ flow 
rate, respectively. It was found that the pressure drop for a single phase flow in the parallel serpentine channel at $5 \mathrm{ml} / \mathrm{min}$ is about 6.8 Pa. At higher flow rates (20 and $30 \mathrm{ml} / \mathrm{min}$ ), the pressure drop increased drastically and flow separations formed around the bends. Therefore, for low flow rates used in the cell, the pressure drop was not significant. Figure 14 also shows that the flow velocity at the corners of the channels is slow. This decrease in velocity could be minimized by rounding the channel corners. It is possible to obtain rounded channel corners in the manufacturing process if using a milling machine.

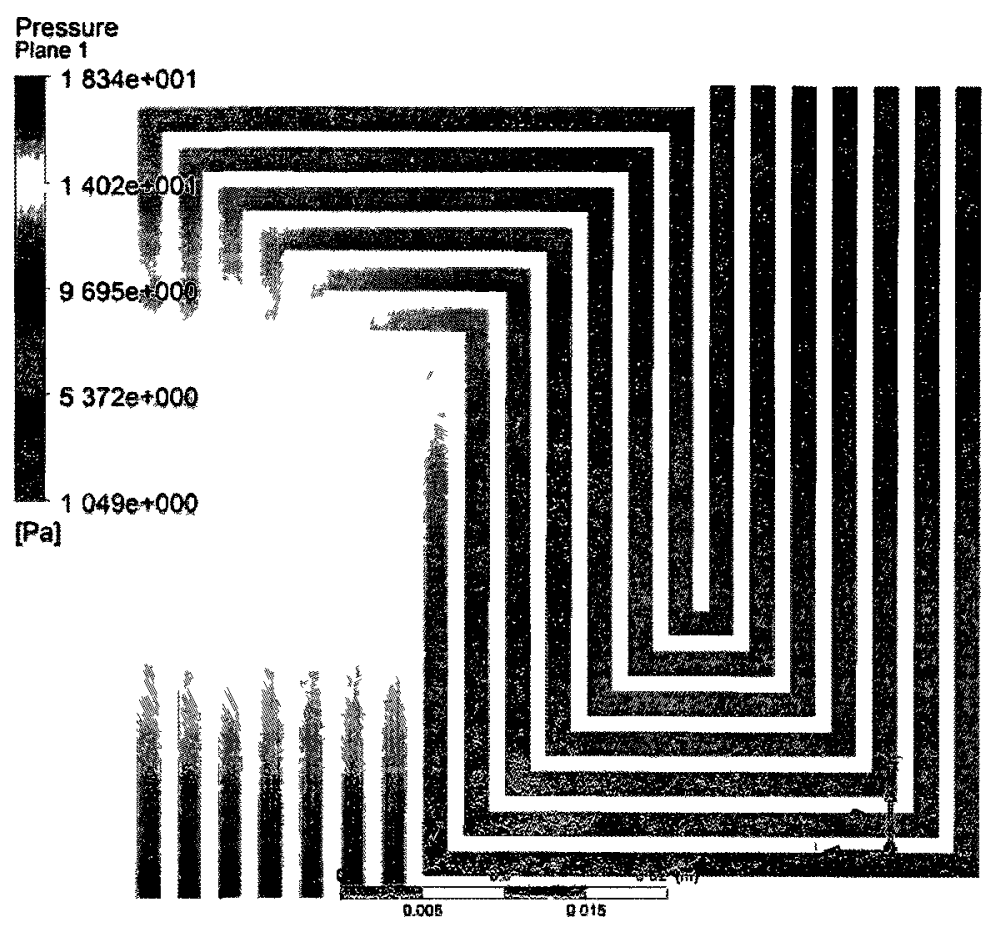

Figure 13: Pressure distribution for $5 \mathrm{ml} / \mathrm{min}$ 


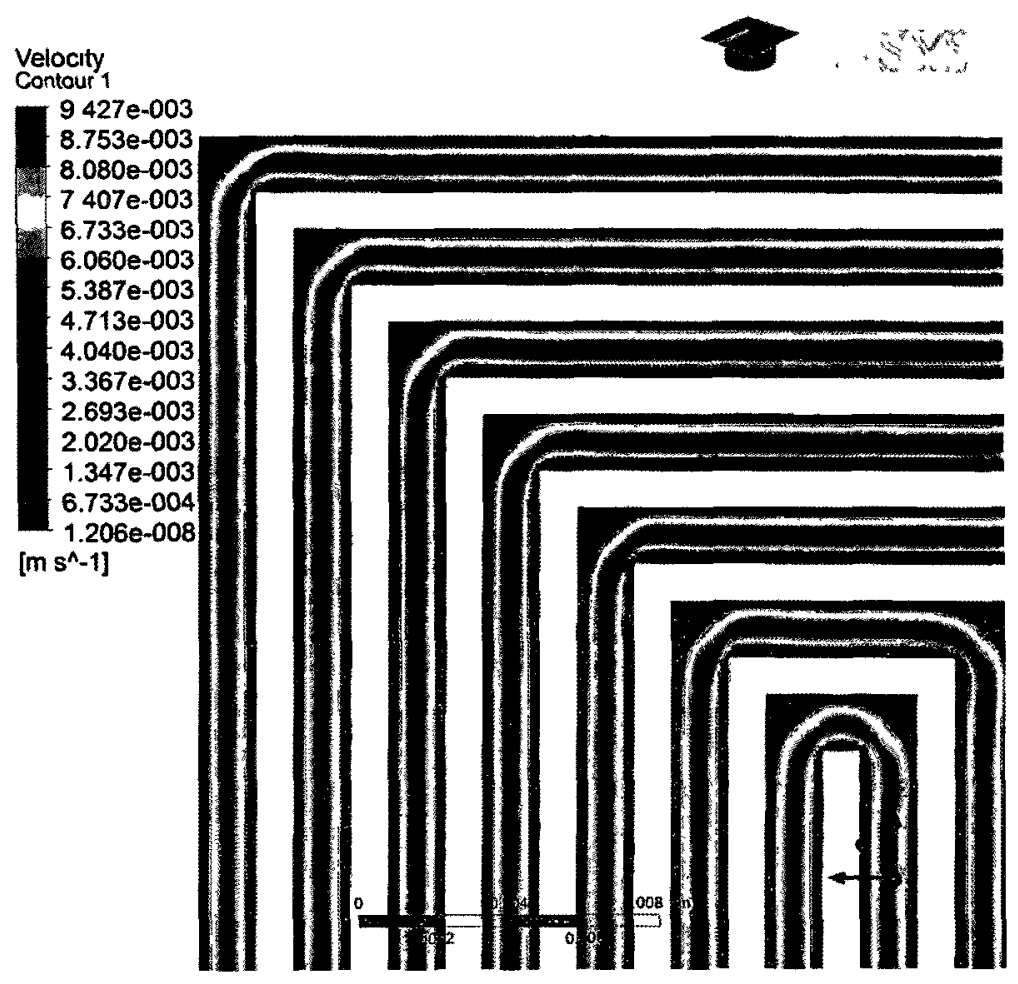

Figure 14: Velocity contour around the bend for $5 \mathrm{ml} / \mathrm{min}$

\subsubsection{Electrodes}

The anode and cathode consist of a GDL and a catalytic layer. The purpose of the GDL is to distribute the reactants to the catalyst layer and to provide an electrical contact between the electrodes and the graphite plates. The gas diffusion layers are made of electrically conductive porous material. Treating these layers with fluoropolymer and carbon black improve water management and electrical properties of the GDL. These layers could also be "wet proofed" by polytetrafluoroethylene (PTFE) in order to make sure that water does not block the pores [7].

For this study, commercially available anode and cathode electrodes were used. Specifically, the gas diffusion layer and catalyst consisted of Toray carbon paper (TGP-H-090) along with $2 \mathrm{mg} / \mathrm{cm}^{2} \mathrm{Pt}$ on the cathode and $2.7 \mathrm{mg} / \mathrm{cm}^{2} \mathrm{Pt}$ in addition to $1.35 \mathrm{mg} / \mathrm{cm}^{2} \mathrm{Ru}$ on the anode. The percent composition list of the electrodes is 
shown in Table 3 .

Table 3: Percent composition list of electrodes

\begin{tabular}{|c|c|}
\hline Components & $\%$ \\
\hline Non-woven carbon fiber & 60 \\
\hline Catalyst & 25 \\
\hline Carbon black & 5 \\
\hline Polytetrafluoroethylene (PTFE) & 5 \\
\hline Polyfluorosulphonicacid (PFSA) ionomer & 5 \\
\hline
\end{tabular}

\subsubsection{Membrane}

Another important component of the fuel cell is the membrane. Polymer exchange membranes (PEM) are the most common electrolytes in DMFCs. Section 2.2.1 contains the details on this component. In this study, the PEM used was Nafion ${ }^{\circledR}$. Nafion ${ }^{\circledR}$ sheets are produced in 1100 and 2100 grams equivalent weight membranes. For this work, Nafion ${ }^{\circledR}$ N-117 and Nafion ${ }^{\circledR}$ NR-212 were used and measure 7 and 2 mil thick, respectively (where $1 \mathrm{mil}$ is one thousandth of an inch).

\subsubsection{Gaskets}

Gaskets are used to seal the fuel cell and provide proper thickness for the flowing electrolyte channel. In this case, it was necessary to find a gasket that was resistant to sulfuric acid at elevated temperature. This task was a challenge. After considerable testing with several materials and designs, PTFE tape and Viton were selected to perform the current study. Wide PTFE (teflon) tape that covered the whole graphite plate was used to fasten the MEA over the serpentine channel. The tape used was $89 \mu \mathrm{m}$ thick and the dielectric strength was up to 9000 Volts. The gasket consisted of 
numerous layers of Viton fluoroelastomer sheets, since they have excellent heat and chemical resistance.

\subsubsection{Flowing electrolyte channel}

Teflon and Viton sheets were initially used to build the FE channel. After testing a number of designs, it was noted that the Nafion ${ }^{\circledR}$ was swelling due to humidity, and that the pressure created by the flowing electrolyte distorted the shape of the channels, resulting in the two Nafion ${ }^{\circledR}$ sheets contacting each other. Figure 15 shows a schematic of two of these designs. The methanol crossover and the contact resistance were both increased as a result, and also caused drastic reduction of the performance of the cell. Therefore, it became obvious that the flowing electolyte channel should also serve as a back pressure provider for the Nafion ${ }^{\circledR}$ in order to prevent the Nafion ${ }^{\circledR}$ sheets from coming in contact.
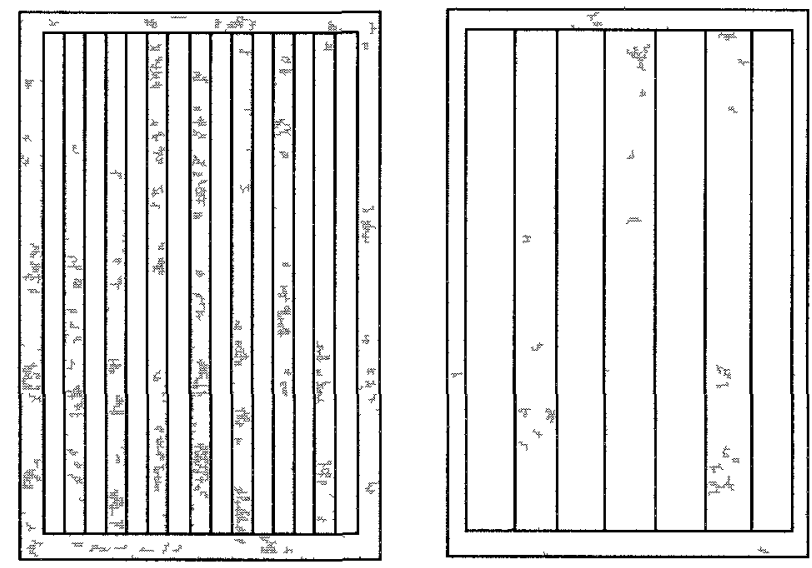

Figure 15: Examples of unsuccessful FE Channel designs

Hydrophilic porous polyethylene sheet was tested and chosen as the flowing electrolyte channel (Figure 16). POREX and Vyon were identified as the hydrophilic polyethylene material to be tested in this study. Using a rigid material next to Nafion ${ }^{\circledR}$ ensured that the two Nafion ${ }^{\circledR}$ sheets would not come into contact and also 
the swelling of the Nafion ${ }^{\circledR}$ would be limited. The microporous and hydrophilic properties of these materials ensures the transfer of ions. Polyethylene is also resistant to sulfuric acid. Table 4 shows the specifications for these materials. Channel thicknesses of $0.6,1.5$, and $2 \mathrm{~mm}$ were tested.

Table 4: Flowing electrolyte channel specifications

\begin{tabular}{|c|c|c|}
\hline Brand & Thickness $[\mathrm{mm}]$ & Pore Size $[\mu \mathrm{m}]$ \\
\hline POREX & 0.61 & $75-110$ \\
\hline POREX & 1.5 & $50-90$ \\
\hline Vyon & 2.0 & $20-40$ \\
\hline
\end{tabular}

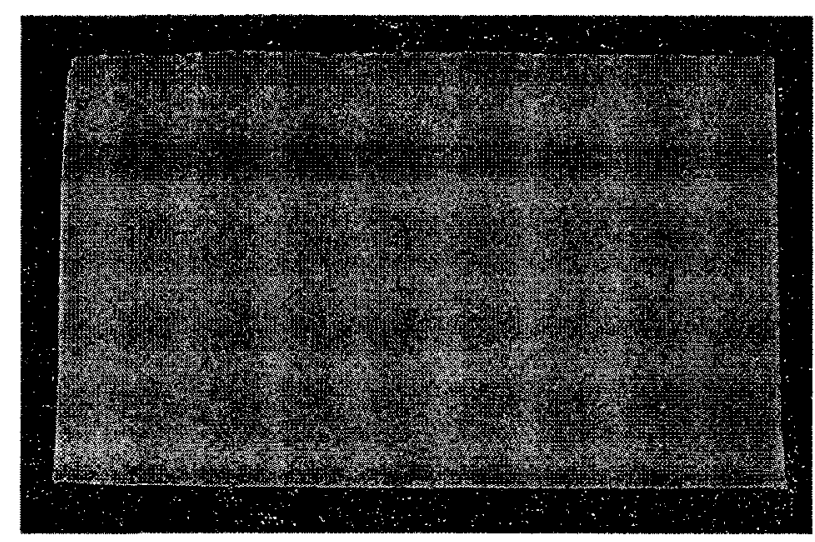

Figure 16: Microporous polyethelene spacer (0.61 mm POREX)

\subsection{Fabrication and assembly}

\subsubsection{Nafion ${ }^{\circledR}$ hydration}

The Nafion ${ }^{\circledR}$ had to be cleaned, activated, and hydrated before it could be used in the fuel cell. Nafion ${ }^{\circledR}$ membranes were kept in warm solutions ( 80 to $100^{\circ} \mathrm{C}$ ) of $3 \%$ hydrogen peroxide, distilled water, $0.5 \mathrm{M}$ sulfuric acid and distilled water again for 1 hour at each solution. 
Hydrogen peroxide $\left(\mathrm{H}_{2} \mathrm{O}_{2}\right)$ was used to remove organic contaminants from the surface of the membrane [7], distilled water was used for hydration, and sulfuric acid was used for activation and full protonation of the Nafion ${ }^{\circledR}[49,50]$. The Nafion ${ }^{\circledR}$ sheets were then stored in distilled water until they were prepared for heat pressing.

\subsubsection{Heat pressing}

Heat pressing allows good interfacial contact when assembling the membrane with the electrodes [51]. The Carver Laboratory Press (Model no: 2697-5) was used for heat pressing in this study (Figure 17). Several combinations of heat pressing conditions were tested, but in all of the cases, full delamination of the GDL and the Nafion ${ }^{\circledR}$ sheet was experienced. Although the catalyst would be transferred to the

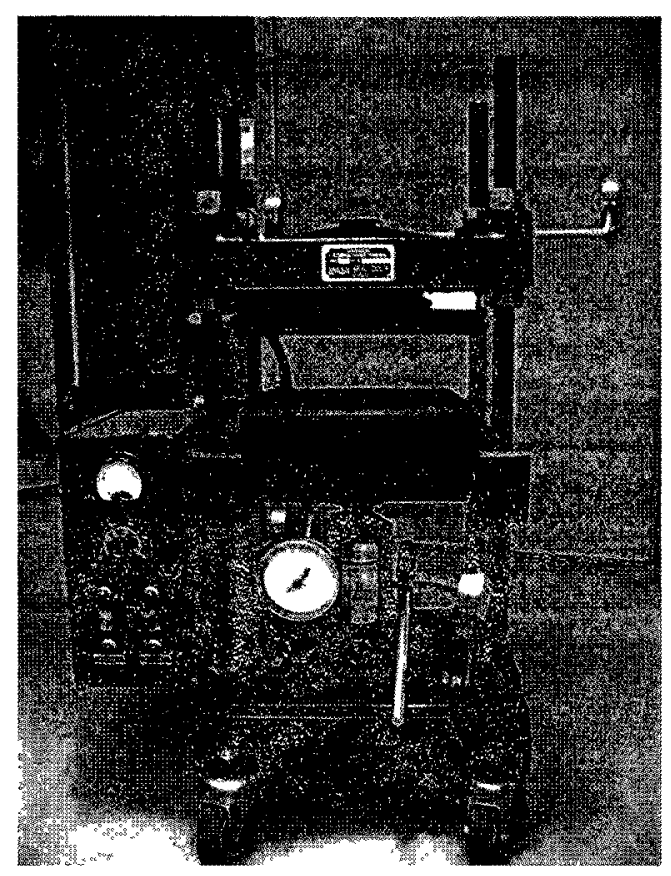

Figure 17: Carver Laboratory Press

Nafion ${ }^{\circledR}$ sheet, delamination of the GDL would result in higher contact resistance. To minimize this, each of anode and cathode electrodes were heat pressed to a different membrane at a pressure and temperature of $3 \mathrm{MPa}$ and $180^{\circ} \mathrm{C}$, respectively, for 3 
minutes. Although partial delamination sometimes occurred using these criteria, the majority of the GDL surface area stayed attached to the Nafion ${ }^{\circledR}$.

\subsubsection{Assembly}

As shown in Figures 5 and 10, each of the half MEAs was sandwiched between the graphite plate and the flowing electrolyte channel. Each MEA was fastened over the serpentine channels using PTFE tape to form a half cell. Figure 18 displays a half cell assembly.

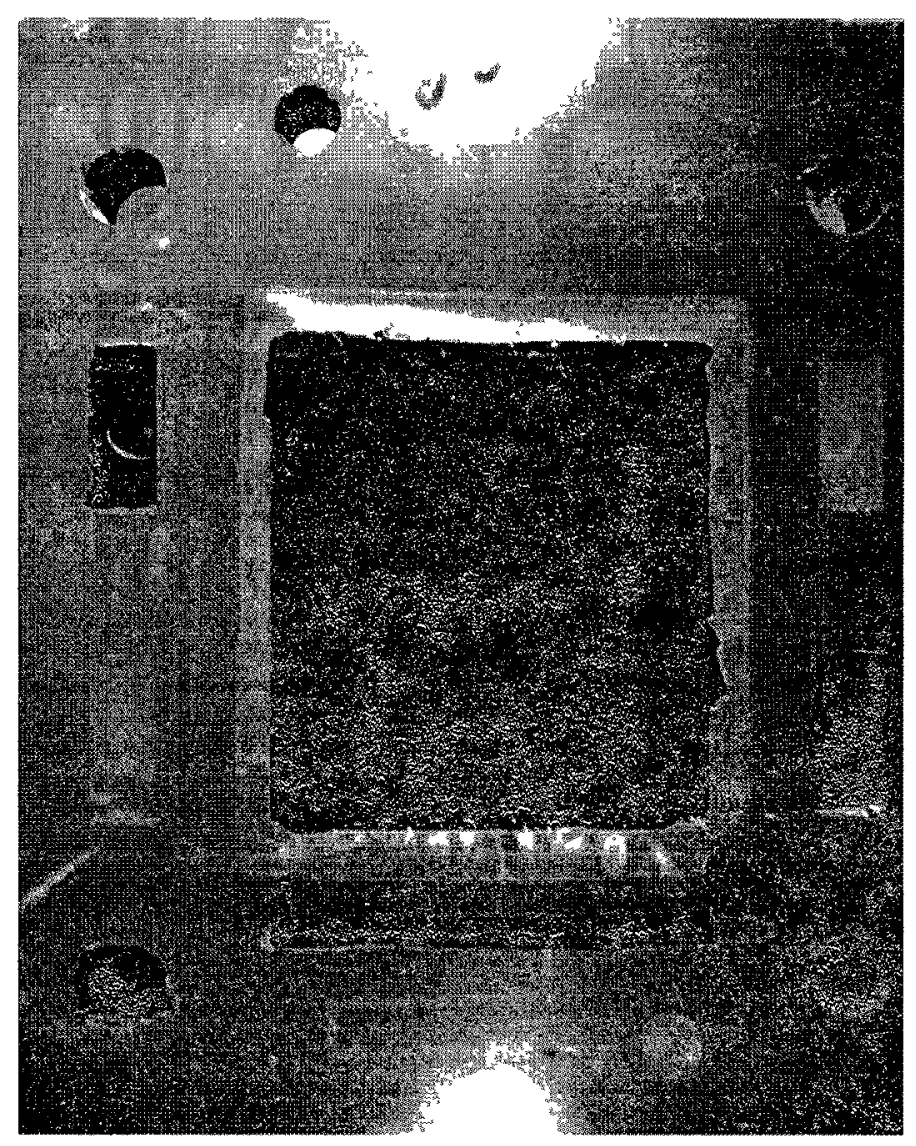

Figure 18: Half cell assembly

A polyethylene microporous spacer was used for the flowing electrolyte channel, and Viton gaskets were used to seal the assembly. All of these components were assembled 
and fastened by grade 8 bolts which were electrically insulated using heat shrink tubing. Preliminary testing had shown that $10.13 \mathrm{~N}-\mathrm{m}$ (90 in-lb) torque produced the best performance of the fuel cell. Lower compression force resulted in leakages, while higher force would crush the electrodes. In a study conducted by Zhu et al. in 2011, it was shown that the compression force has a significant effect on the ohmic and mass transfer resistances [52]. Figure 19 shows the 3D model of the cell after assembly.

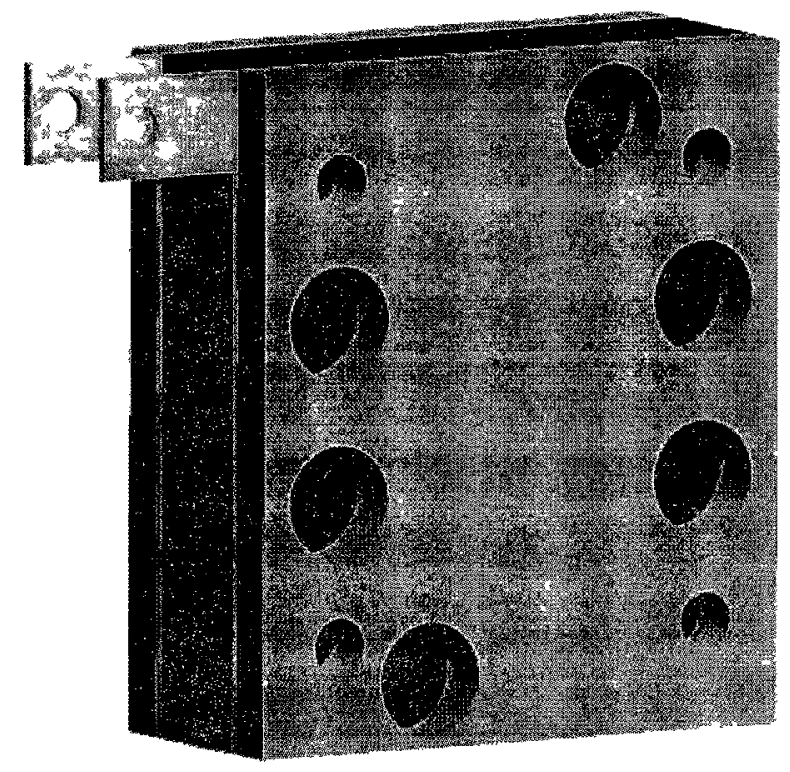

Figure 19: 3D Model of DMFC after assembly

\subsubsection{Hydration process}

As mentioned previously, hot pressing caused dehydration of the Nafion ${ }^{\circledR}$ membrane, which resulted in low ionic conductivity $[42,50]$. Therefore, a conditioning operation was conducted after the MEA was installed in the fuel cell in order to increase the ionic conductivity of the membrane and also enhance the catalytic reactions [50]. Since the purpose of the rehydration process was to hydrate the 
membrane and improve the ionic conductivity of the membrane, the method used was based on the one developed by Tse [50].

This method involves pumping the water through the fuel and the flowing electrolyte channels while Nitrogen gas is supplied to the oxidant channels until the cell reaches $85^{\circ} \mathrm{C}$. In the next step, $2 \mathrm{M}$ methanol, $2 \mathrm{M}$ sulfuric acid and air are supplied to fuel, flowing electrolyte and oxidant channel, respectively. The fuel cell is then operated at open circuit voltage and $0.3 \mathrm{~V}$ for $15 \mathrm{~min}$ each, repeatedly for 8 hours or until the current and voltage reach a stable state.

In the next chapter, the components used in the experimental setup and the uncertainty analysis of the experimental measurements are discussed. 


\section{Chapter 4}

\section{Experimental Setup and Uncertainty}

\section{Analysis}

\subsection{Experimental setup}

The experimental setup for this study was developed in-house. As illustrated in Figure 20, this setup consisted of three main parts: fluid control, temperature control, and electric load. The fluid control section has three main subsections that are responsible for the delivery of the methanol solution, sulfuric acid solution and the air to the fuel cell, and also the removal of the products from the fuel cell. The temperature control section is responsible for keeping the operating temperature of the fuel cell constant by regulating the heaters that are attached to the fuel cell. Finally, the load is simulated by the load bank and the computer records the voltage, current and power generated by the fuel cell.

A picture of the experimental setup is shown in Figure 21. The experiments were conducted in a fume hood as methanol and sulfuric acid vapours are toxic. The fuel cell was placed in a Faraday cage in order to ensure that no external signals affected the performance. Fresh diluted methanol and sulfuric acid were pumped from the 


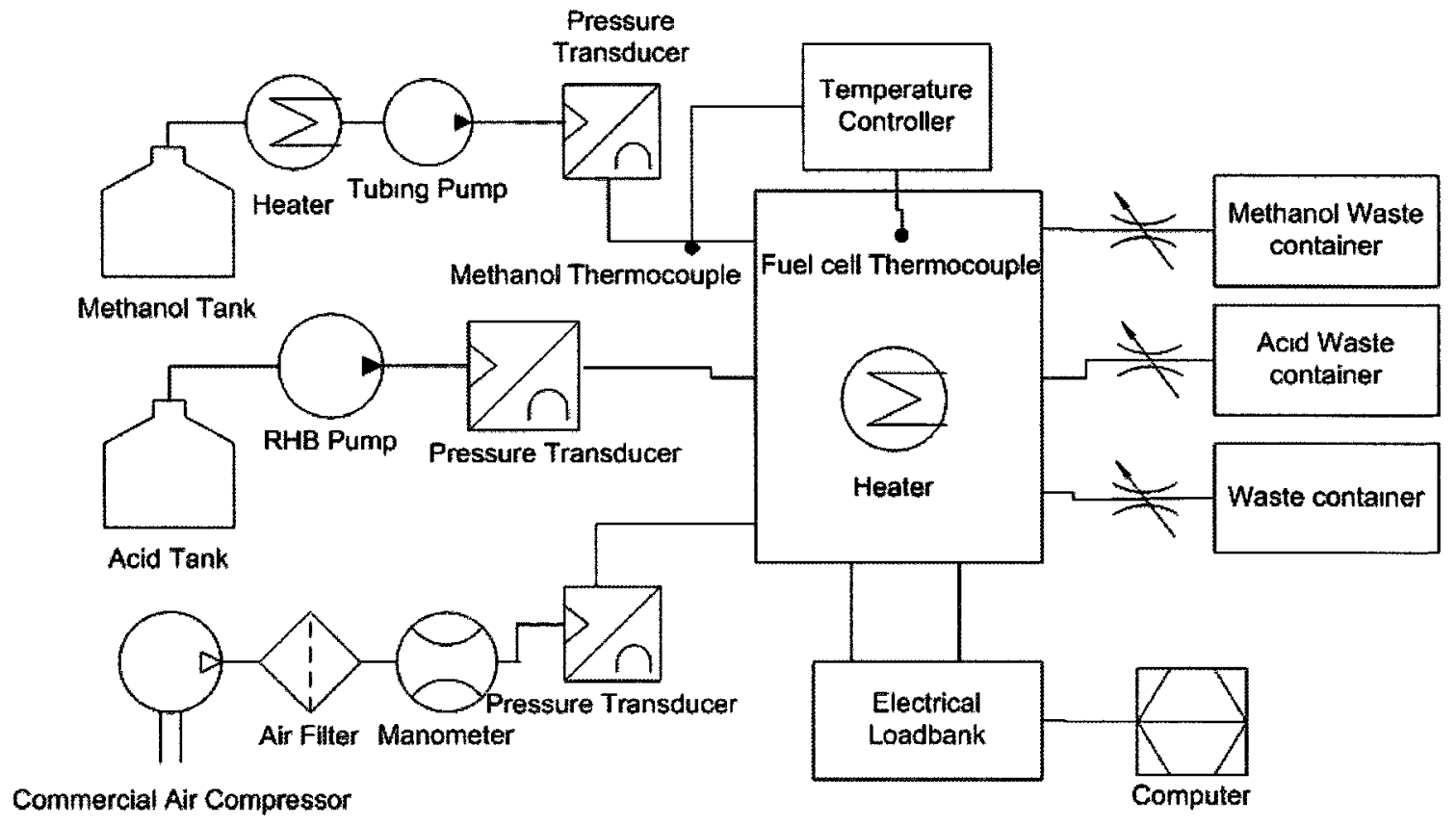

Figure 20: Schematic of experimental setup

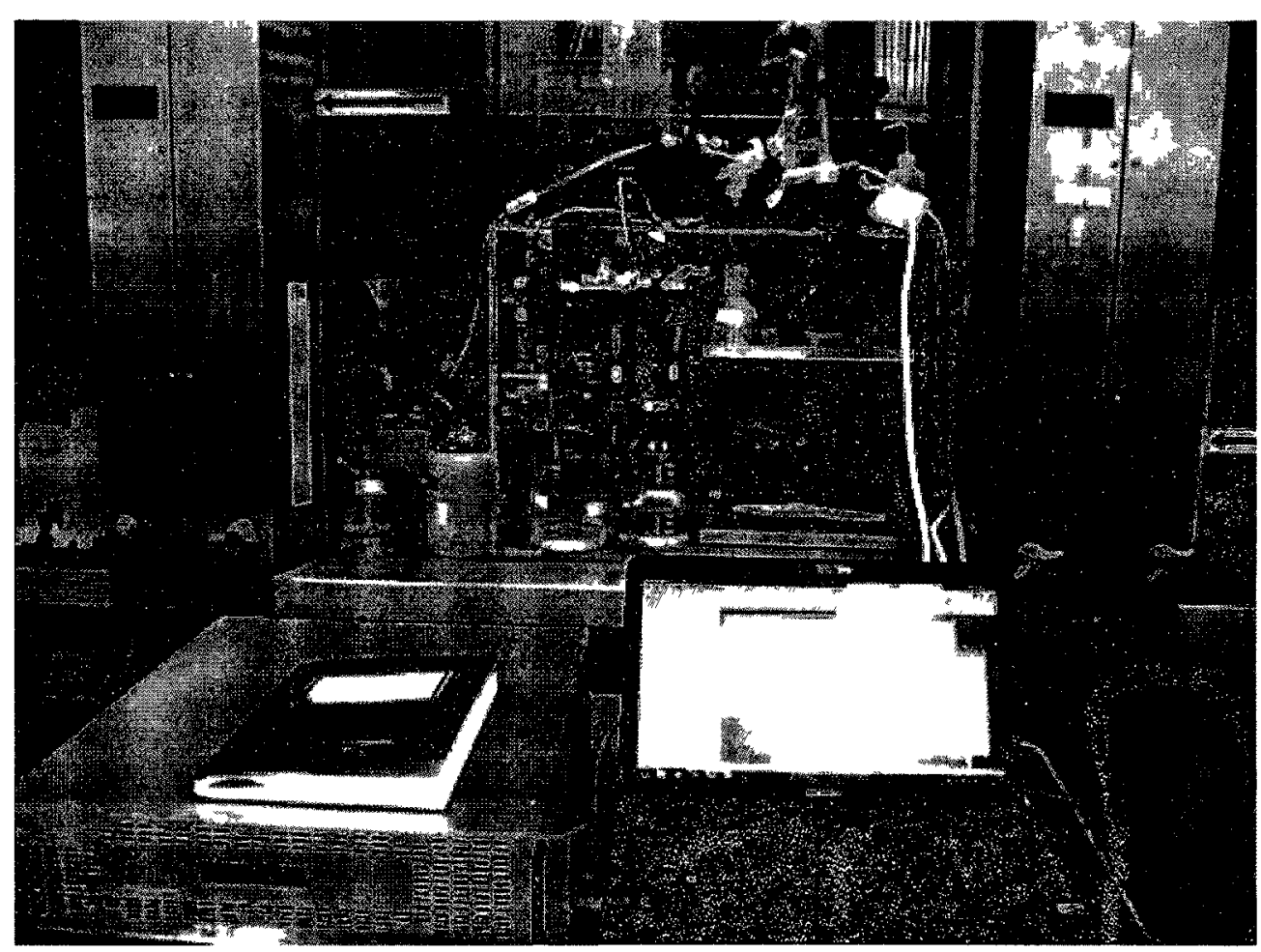

Figure 21: Experimental setup 
blue lid containers, shown in Figure 21, and the waste was accumulated in beakers. The laptop computer and the load bank are also shown in front of the fume hood. This chapter contains a detailed explanation of each of the sub-systems and their components.

\subsubsection{Fluid control}

The fluid control of the experimental setup consisted of components that were used to control and measure the reactants flow rates and pressure. Air was supplied from a compressor and passed through an air filter and then into the rotameter. Diluted methanol and sulfuric acid were pumped into the cell. Digital pressure transducers (GE Druck PMP 1210) were installed in order to read the fluid pressures in the cell. Finally needle valves were installed at the outlets of the cell, which allowed the control of the pressure. The main components of fluid control were identified as the pumps, rotameter, air filter, pressure transducer and needle valve. The specifications for these components are listed in the followings sections.

\section{Pumps}

Diluted methanol and sulfuric acid are pumped with a peristaltic pump (MASTERFlex C/L Pump) and a Fluid Metering Inc. (RHB model) pump into the cell, respectively. The peristaltic pump was chosen because it covers a wide range of flow rates for pumping the methanol solution and the RHB pump as it is compatible with sulfuric acid. Tygon tubing (S-50-HL) was used. It should be noted that no degradation of the tubes were observed during the testing period. Table 5 presents the characteristics of the MASTERFlex and the Fluid Metering pumps and Table 6 presents the flow rates for the MASTERFlex pump with respect to internal diameter of the tube at room temperature and 0 psi. The 
RHB pump was powered through a SAMLEX regulated DC power supply (RPS1210).

Table 5: Pumps Characteristics

\begin{tabular}{|c|c|c|}
\hline Brand & MASTERFlex & Fluid Metering Inc. \\
\hline Model & C/L-77122-22 & RHB - PM6013 \\
\hline Speed (rpm) & 50 to 300 & 2200 \\
\hline Electrical Requirement & 115 V AC, $400 \mathrm{~mA} \mathrm{AC}$ & 12 VDC, 4.3 AMP \\
\hline Material & $\begin{array}{c}\text { Polyphenylene sulphide (PPS), } \\
\text { polyester and stainless steel }\end{array}$ & $\begin{array}{c}\text { wetted parts: } \\
\text { Ceramic \& PVDF }\end{array}$ \\
\hline Flow Rate (ml $/ \mathrm{min})$ & See Table 6 & 0 to 260 \\
\hline Temperature $\left({ }^{\circ} \mathrm{C}\right)$ & $0-40$ & - \\
\hline
\end{tabular}

Table 6: MASTERFlex pump flow rate with respect to tubing internal diameter

\begin{tabular}{|c|c|c|}
\hline \multirow{2}{*}{ Tubing Internal Diameter $(\mathrm{mm})$} & \multicolumn{2}{|c|}{ Flow rate $(\mathrm{ml} / \mathrm{min})$} \\
\cline { 2 - 3 } & $80 \mathrm{rpm}$ & $300 \mathrm{rpm}$ \\
\hline 1.14 & 3.1 & 13 \\
\hline 1.42 & 4.5 & 19.1 \\
\hline
\end{tabular}

\section{Rotameter: Gilmont GF-9360}

The rotameter was used to measure the air flow rate. This rotameter was chosen since the valve allows proper adjustment of the air flow. The Gilmont GF-9360 had the follow specifications:

- Shielded with valves;

- Material: PTFE;

- Valve can be adjusted from 0.1 to $100 \%$ of maximum flow (semi-logarithmic);

- Precise regulation from 0.3 to $60 \%$ of maximum flow; and 
- Accuracy: $5 \%$ of reading or $2 \mathrm{~mm}$ of the scale length, whichever is greater.

\section{Air Filter}

An air filter was chosen to remove particles bigger than 1 micron. The specifications of this air filter are listed as:

- Removes particles as small as 1 micron;

- Maximum flow rate: $20 \mathrm{scfm}$ of flow;

- Maximum pressure: $100 \mathrm{psi}$; and

- Maximum operating temperature: $125^{\circ} \mathrm{F}$.

\section{Pressure Transducer: GE Druck PMP 1210}

The pressure transducer measured the pressure of the reactants within the fuel cell. This transducer was chosen as it allows measurements up to 15 psi (gauge) and an additional advantage is that it can also be used for the testing of a stack in the future. Also, the internal material is compatible with sulfuric acid. The GE Druck PMP 1210 transducers had the following specifications:

- Operating pressure: 0 to 15 psi range;

- Outer shell material: 316L Stainless Steel;

- Pressure media: Hastelloy C27;

- Electrical requirements: 0-30 Vdc, less than $2 \mathrm{~mA}$;

- Output :1-5 Vdc (less than 2mA); and

- Operating Temperature Range: -40 to $+185^{\circ} \mathrm{F}$.

- accuracy: $0.25 \%$ 


\section{Valve: OMEGA PTFE Needle Valve}

The needle valve was used to adjust the pressure of the flow. The internal components of this valve are made of PTFE material, making them resistant to sulfuric acid. Its specifications are:

- Maximum pressure: $517 \mathrm{kPa}$;

- Maximum temperature: $65^{\circ} \mathrm{C}$;

- Orifice size: $3.175 \mathrm{~mm}$ diameter;

- Materials of construction fluid contacting:

- Body and O-ring: PTFE

- Valve spindle-CTFE.

\subsubsection{Temperature control}

In order to maintain a constant temperature, two flat heaters were glued to the end plates of the fuel cell. The temperatures of the cell and the methanol inlet were read by Type $\mathrm{K}$ thermocouple into an Omega temperature controller that regulates the energy transfer to the heaters by a relay. The thermocouple that measures the operating temperature of fuel cell is located in a hole that is drilled on the side of the anode graphite plate. A detail drawing of the temperature controller wiring is presented in Appendix C.

\section{Temperature Controller: OMEGA CN-79000}

The temperature controller was used to keep the operating temperature of the cell at a specific temperature. This temperature controller was chosen as it allows for two separate controls, one of which was used to control the fuel cell operating temperature and the other to read the temperature of the methanol solution at the cell entrance. The specifications of the OMEGA CN-79000 are: 
- On - Off differential: adjustable $1^{\circ} \mathrm{F}, 1^{\circ} \mathrm{C}$, or 1 count to full scale in $1^{\circ} \mathrm{F}, 1^{\circ} \mathrm{C}$, or 1 count steps;

- Supply voltage: 100 to $240 \mathrm{~V} \mathrm{AC}$, nominal, +10 -15\%, 50 to $400 \mathrm{~Hz}$;

- Operating temperature: -10 to $+55 \mathrm{C}(+14$ to $131 \mathrm{~F})$; and

- Accuracy: $0.25 \%$ of span, 1 least significant digit.

\section{Thermocouple: TEF-30-K}

This type of thermocouple was chosen due to its small diameter and also its Teflon coating. The coating protects the thermocouple from coming into direct contact with sulfuric acid and corroding. The thermocouple used in this study had the following characteristics:

- Type K thermocouple from J-KEM SCIENTIFIC INC;

- Thin chromel-alumel wires sealed with teflon;

- Diameter: 0.064 mm Length: 36";

- Response time is 0.1 seconds; and

- Operating temperatures: -250 to $204{ }^{\circ} \mathrm{C}$.

- Precision error: the greater of $2.2{ }^{\circ} \mathrm{C}$ or $0.75 \%$ of range

\section{Heater: OMEGALUX silicone rubber fiberglass insulated heater}

The heaters which were used to increase the cell temperature had the following specifications:

- Size: 2 in $x 3$ in

- Circuit design: etched foil;

- Maximum operating temperature: $120^{\circ} \mathrm{C}$;

- Voltage: $115 \mathrm{VAC}$; and

- Watt density: $10 \mathrm{~W} / \mathrm{in}^{2}$. 


\subsubsection{Electrical load}

In order to measure the output performance of the cell, an electrical load was required. Load banks are devices designed to provide electrical loads for testing power sources. Different loads can be simulated using software. The load bank reads the current and the voltage of the cell and records the data in the computer. A Fideris (Innovator Series-250 kW) load bank was used in this setup. The load bank was controlled by a software called FC Power. The FC Power program allows a user to operate the fuel cell in different modes such as constant current, voltage and power, and also has the capacity to ramp between two limits or pulsate in 2 different levels (which would be defined by the user). A brief introduction on how to use this software is provided in Appendix D. For more detail on this software, refer to the Instruction Manual for FCPower Control Software v2.1: Software component of the Fideris ${ }^{T M}$ Fuel Cell Test System (FCTS) Testing Family.

\section{Fideris $^{\top M}$ Innovator Series $^{\top M}$}

The limitations and characteristics of the Fideris load bank are listed below.

- Type: MOSFET variable resistance load bank;

- Current measurement: Exchangeable shunt (1, 20, 50 Amps);

- Maximum current rating: $50 \mathrm{~A}$;

- Maximum voltage rating: $20 \mathrm{~V}$;

- Maximum power dissipation: $250 \mathrm{~W}$;

- Load capacitance $<25 \mathrm{pF}$;

- Corrosion protection: All critical components are silver or gold plated;

- Electrical requirements: 26-50 VDC; and

- Communication: Ethernet (requires DHCP). 


\section{Toshiba Laptop}

The FC power was installed on a Toshiba laptop, which was used to control the load bank. The specifications of the laptop are listed:

- Processor: Intel Core i3 $2.27 \mathrm{GHz}$;

- Memory: 4 GB; and

- Hard drive: $300 \mathrm{~GB}$.

\subsection{Uncertainty analysis of the measurement}

Kline and McClintock refer to "uncertainty" as "a possible value that an error may have" [53]. Moffat also describes the term uncertainty as an "interval around the measured value within which the true value is believed to lie" [54]. The total error of a measurement consists of bias and random precision errors. Bias error is constant for the duration of the test and is usually an accumulation from several individual bias errors. The random error are observed and they are not usually constant due to numerous error sources [55].

In this section, an error analysis using the ANSI/ASME PTC 19.1-1985 was followed [55]. This method involves identifying the measurement process, listing the elemental error sources and the estimation of the elemental errors. The main error sources were identified to be the temperature and flow rate measurements (i.e., the anode, FE and cathode flow rates), the FE thickness and pressure, the compression torque, the methanol and sulfuric acid concentrations, as well as, the load bank measurements. This analysis is shown in Appendix E. It should be noted that the current analysis is based on the experiments done on the first generation of the FE-DMFC. Factors such as catalyst loading, graphite conductivity, PEM proton 
conductivity based on relative humidity and many other factors should be studied in the future.

Results from the uncertainty analysis include a bias error of $12 \mathrm{mV}$ and $3.4 \mathrm{~mA} / \mathrm{cm}^{2}$ for voltage and current density, respectively. The random error was also found to be $14 \mathrm{mV}$ and $4.6 \mathrm{~mA} / \mathrm{cm}^{2}$ for voltage and current density, respectively. For the maximum power density, where the current density is $136.3 \mathrm{~mA} / \mathrm{cm}^{2}$ and voltage is $247.4 \mathrm{mV}$, the uncertainty analysis indicated that the $99 \%$ and $95 \%$ confidence levels were $18.5 \%$ and $14 \%$, respectively. 


\section{Chapter 5}

\section{Effects of Operating Conditions on the Performance of the Fuel Cell}

The flowing electrolyte-direct methanol fuel cell material and fabrication method, as well as, the experimental setup were discussed in Chapters 3 and 4 , respectively. In this chapter, the experimental results are presented and discussed. The purpose of this study was to determine the effects of different operating conditions on the performance of FE-DMFC. In this study, two different types of membrane electrode assembly were constructed. Table 7 contains a list of components that made up these MEAs. The total Nafion ${ }^{\circledR}$ thickness for Type 1 and Type 2 MEAs are $9(7+2)$ and $4(2+2)$ mil, respectively. Figure 22 illustrates the MEA types used in this study. It should be noted that the components are not drawn to scale.

Table 7: MEA structure

\begin{tabular}{|c|c|}
\hline Type 1 & Cathode + Nafion ${ }^{\circledR} 117+$ FE channel + Nafion ${ }^{\circledR} 212+$ Anode \\
\hline Type 2 & Cathode + Nafion ${ }^{\circledR} 212+$ FE channel + Nafion ${ }^{\circledR} 212+$ Anode \\
\hline DMFC & Cathode + Nafion ${ }^{\circledR} 117+$ Anode \\
\hline
\end{tabular}




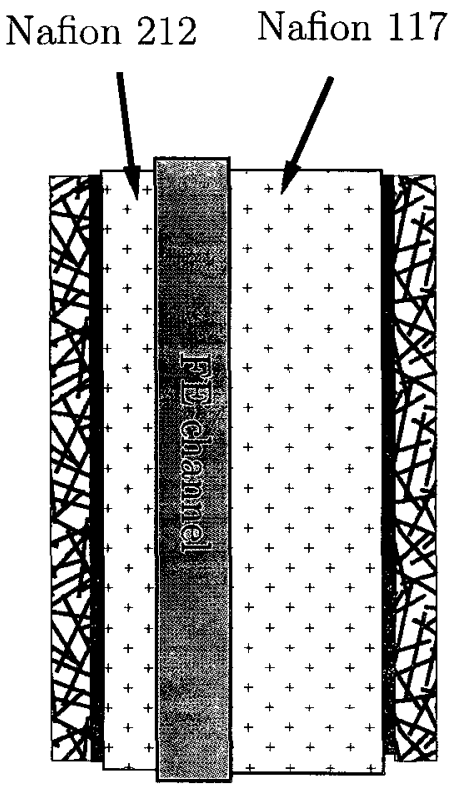

Type 1

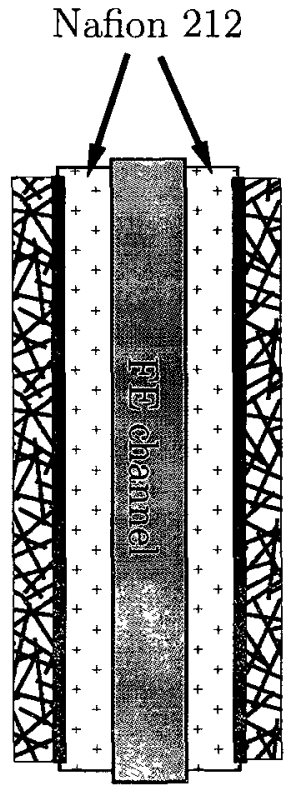

Type 2

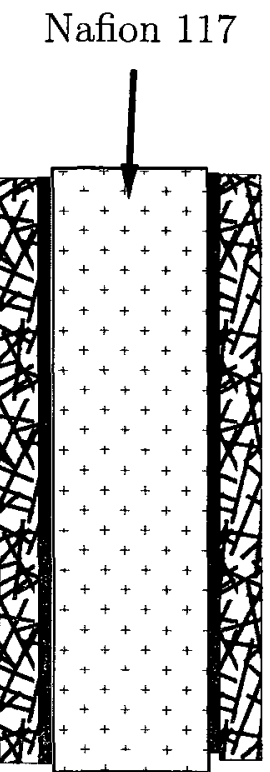

DMFC

Figure 22: MEA configurations

The operating conditions that were studied were flow rate and pressure for methanol and air, respectively. Controlling the pressure of the methanol in the methanol channel proved to be difficult with the current equipment due to the bubbly nature of the anode flow, especially at high current densities. Extensive preliminary testing of the fuel cell showed that changing the air flow rate and back pressure did not alter the performance of the fuel cell, as long as air was supplied in excess. Therefore, the needle valves at the methanol and air outlets were kept open for all of the experiments. Methanol and flowing electrolyte flow rates were kept at $5 \mathrm{ml} / \mathrm{min}$. The operating temperature of the fuel cell was measured at the anode graphite plate and was kept constant at $85^{\circ} \mathrm{C}$, unless otherwise specified. Based on preliminary experiments, it was seen that the performance of the cell improved with increasing air flow rate from 60 to $400 \mathrm{ml} / \mathrm{min}$. Increasing the air flow rate further to $600 \mathrm{ml} / \mathrm{min}$, however, did not change the power output. Therefore, air was provided in excess (from the electrochemical point of view), at $600 \mathrm{ml} / \mathrm{min}$, for all of the experiments. 


\subsection{FE-DMFC performance}

The performance of a fuel cell is measured by the amount of current that it can produce for a certain voltage and the amount of power that it can generate, per amount of fuel. For a typical test, the load bank was initially set to $0 m A$ (which corresponds to OCV) and then the current was increased in $10 \mathrm{~mA}$ increments until it reached the upper limit. The sweep time was set to 5 minutes for all of the experiments.

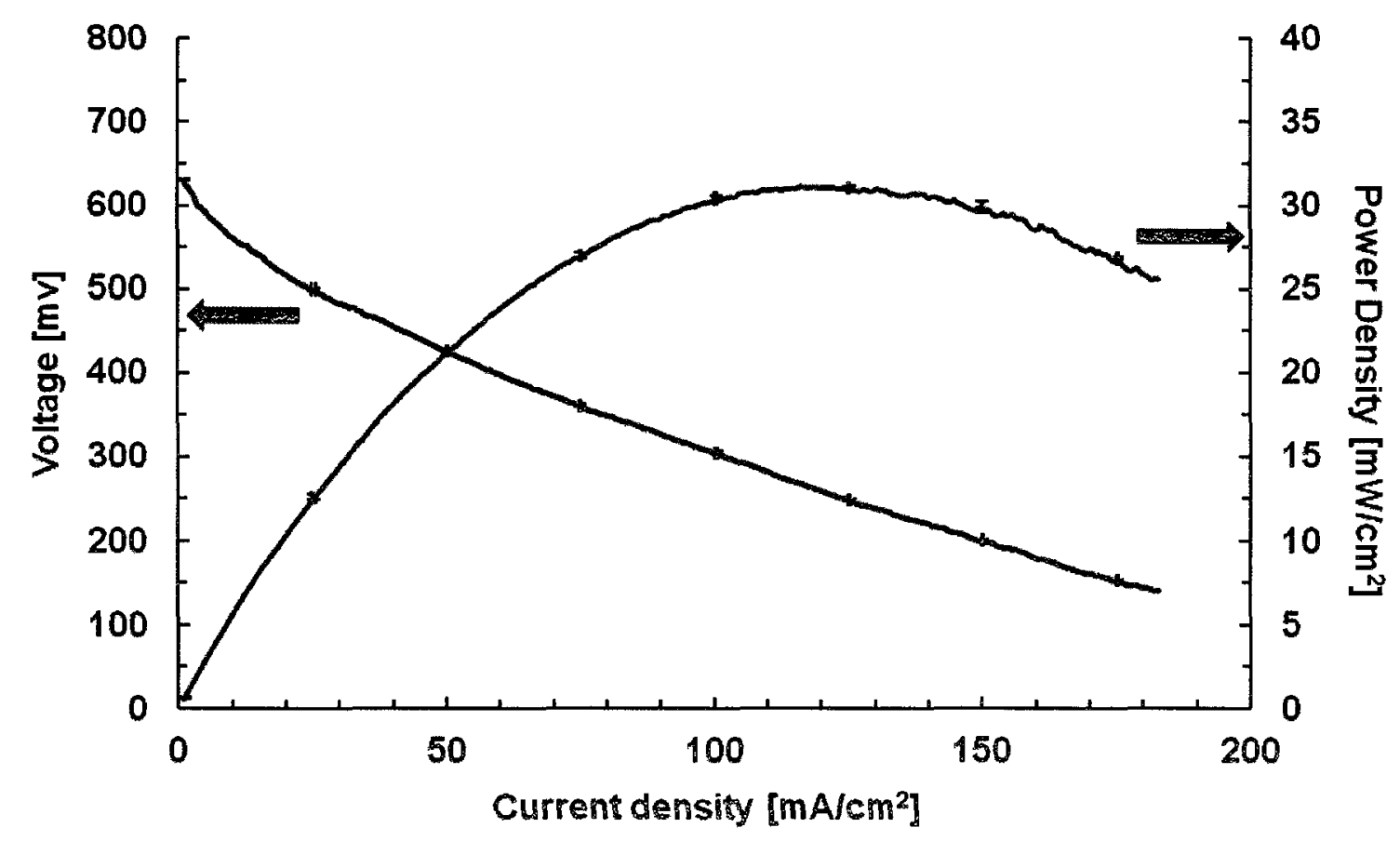

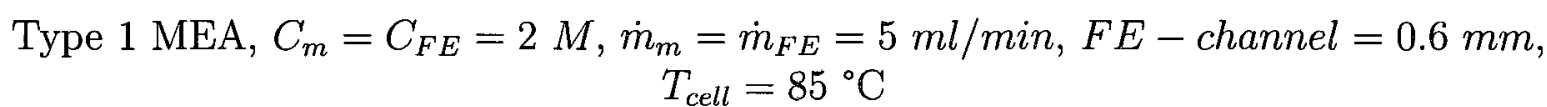

Figure 23: Polarization and power density curves

Figure 23 shows a polarization and a power density curve for the Type 1 MEA at a typical operating condition. In this graph, the voltage and the power density are both shown as a function of current density. At no load, $670 \mathrm{mV}$ is produced by the FE-DMFC when $2 \mathrm{M}$ methanol and $0.6 \mathrm{~mm} \mathrm{FE}$ channel were used. It is apparent 
that the activation overpotential rapidly drops the voltage to about $550 \mathrm{mV}$. It should be noted that the concentration losses region is not demonstrated since the slope of the curve is high and the voltage decreases significantly as the current increases. In this case, the power density is calculated by multiplying the voltage and the current density. The maximum power density produced by this fuel cell was $33.7 \mathrm{~mW} / \mathrm{cm}^{2}$ at $136.3 \mathrm{~mA} / \mathrm{cm}^{2}$ for these operating conditions.

\subsubsection{Repeatability of results}

In order to ensure the repeatability of results, several MEAs were constructed under the same conditions and were tested. Figure 24 shows the performance of a Type 1 MEA operating with a $0.6 \mathrm{~mm}$ flowing electrolyte channel and $2 \mathrm{M}$ methanol. In

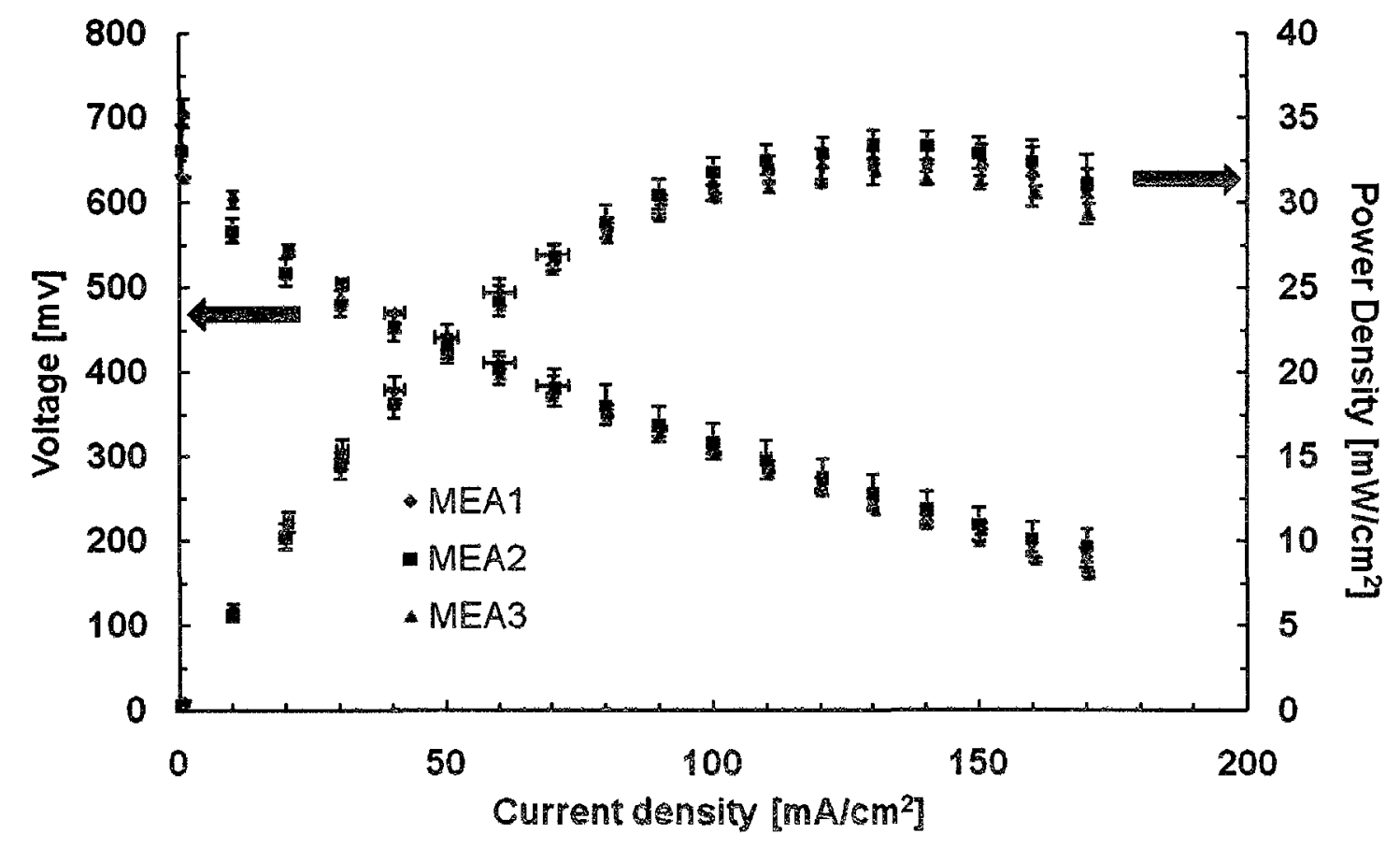

Type $1 \mathrm{MEA}, C_{m}=C_{F E}=2 \mathrm{M}, \dot{m}_{m}=\dot{m}_{F E}=5 \mathrm{ml} / \mathrm{min}, F E-$ channel $=0.6 \mathrm{~mm}$, $T_{\text {cell }}=85^{\circ} \mathrm{C}$

Figure 24: Repeatability of results 
this case, three MEAs were constructed in the same manner and their performance is shown to be similar and within the standard deviation. The average of the three cycles for the polarization curve and the standard deviation for the error bar have been shown.

\subsection{Effects of flowing electrolyte}

The effects of the flowing electrolyte (FE) were tested qualitatively by observing the changes of OCV and current when altering the flowing electrolyte flow. Figure 25 shows the effects of FE flow on the OCV. As shown, the voltage decreases upon stopping the flowing electrolyte. This is due to methanol crossover. Once the flowing electrolyte is present, the voltage increases again.

Figure 26 illustrates the effect of FE flow on the current density produced by the cell while the voltage is fixed at $200 \mathrm{mV}$. In this case, the current drops rapidly after stopping the flowing electrolyte. The observations made during these tests are consistent with the idea that the methanol crossover increases upon stopping the flowing electrolyte flow, which results in a decrease in the performance of the fuel cell.

Therefore, the concept of the flowing electrolyte proved to be beneficial for the removal of the crossed over methanol and improving the performance of a direct methanol fuel cell. 


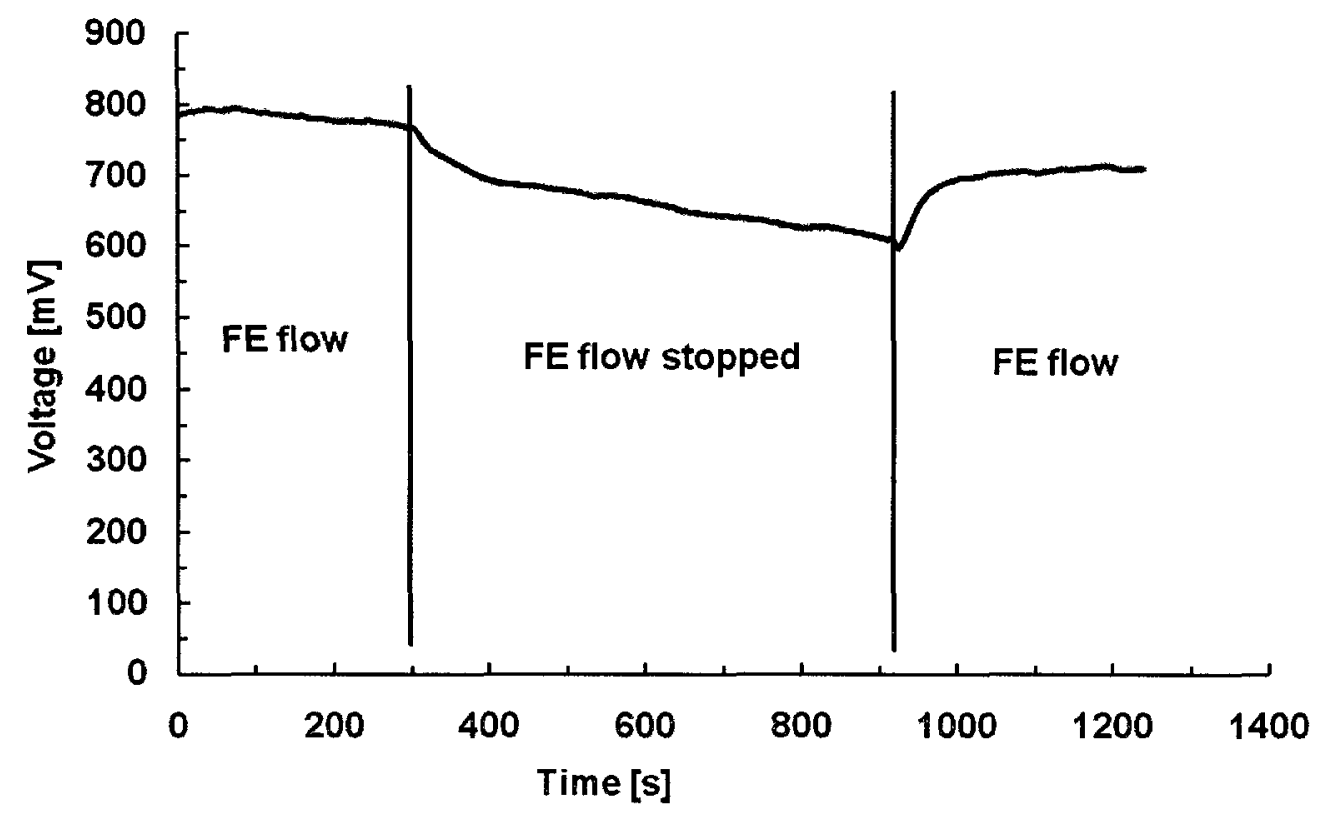

Type $1 \mathrm{MEA}, C_{m}=C_{F E}=2 \mathrm{M}, \dot{m}_{m}=5 \mathrm{ml} / \mathrm{min}, F E-$ channel $=0.6 \mathrm{~mm}$, $T_{\text {cell }}=85^{\circ} \mathrm{C}$

Figure 25: Effects of FE flow on the OCV

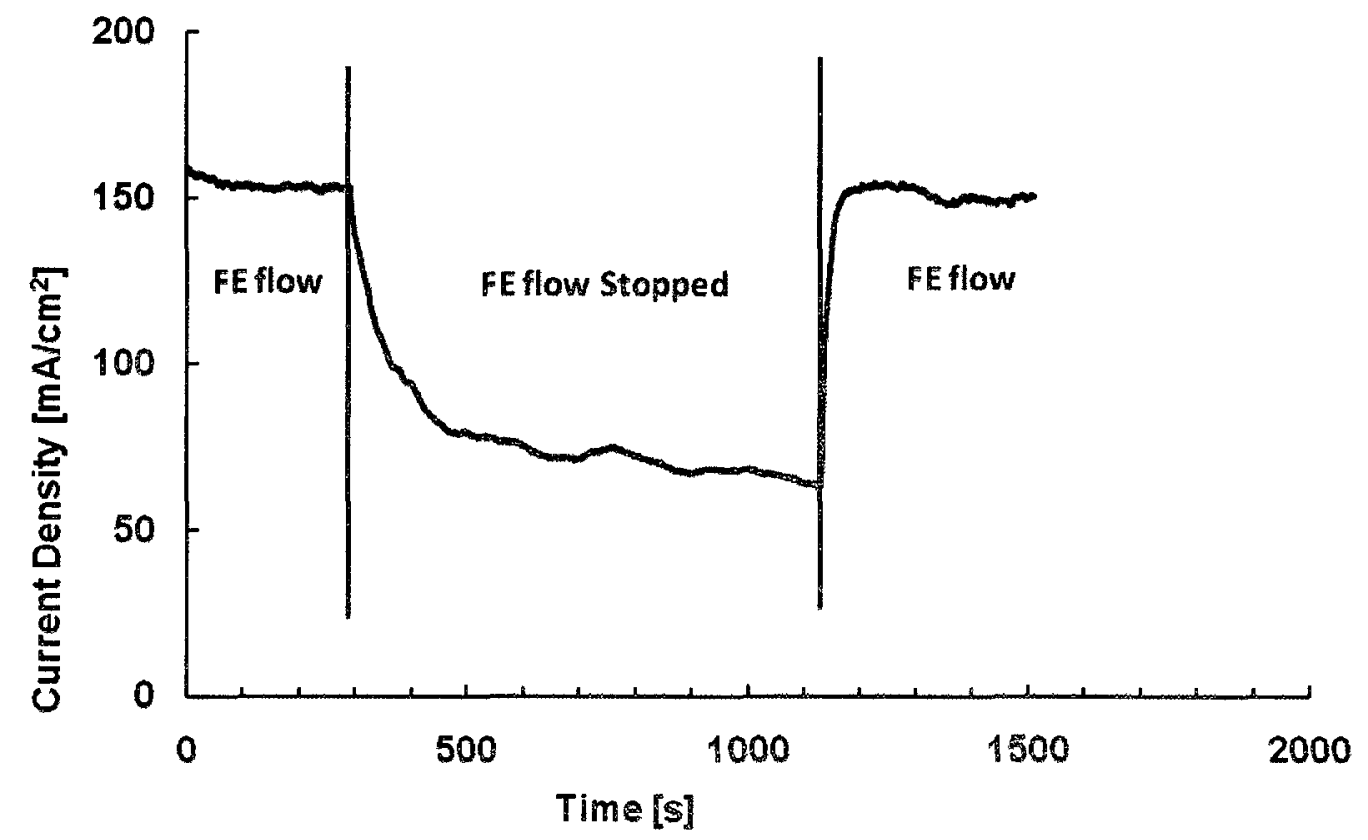

Type $1 \mathrm{MEA}, C_{m}=C_{F E}=2 \mathrm{M}, \dot{m}_{m}=5 \mathrm{ml} / \mathrm{min}, F E-$ channel $=0.6 \mathrm{~mm}$, $T_{\text {cell }}=85^{\circ} \mathrm{C}$

Figure 26: Effects of FE flow on current density 


\subsubsection{Effects of flowing electrolyte concentration}

Electrolytes dissociate in polar solvents to form charged species (ions) [56]. Strong acids fully dissociate in water to produce $H^{+}$or hydronium ions $\left(\mathrm{H}_{3} \mathrm{O}^{+}\right)$[57]. For strong electrolytes, the resistivity and the conductivity are dependent on the electrolyte concentration $[56,57]$. At higher concentrations, the conductivity is lower than direct proportionality, which is due to constricted ionic movement as a result of higher interionic forces [56]. Figure 27 shows the conductivity of sulfuric acid (in siemens, S) as a function of concentration for different temperatures based on Darling's study [58]. This figure shows that sulfuric acid is mostly conductive at about $35 \%$ (which corresponds to $3 \mathrm{M}$ ) and the conductivity increases with temperature.

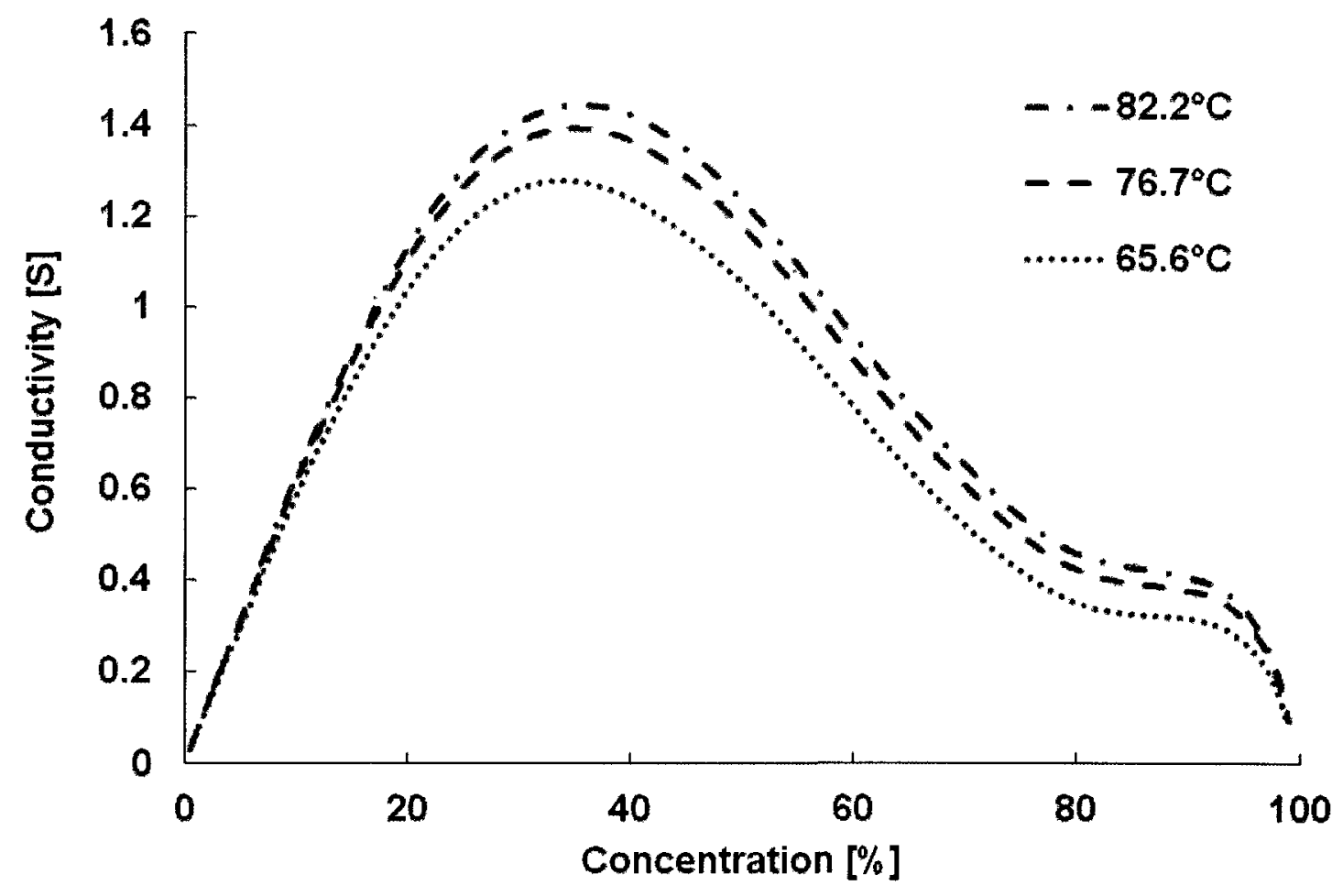

Figure 27: Sulfuric acid conductivity 
Figure 28 illustrates the performance of the fuel cell for $1 \mathrm{M}(10 \%), 2 \mathrm{M}(20 \%)$ and $3 \mathrm{M}(35 \%)$ sulfuric acid and Table 8 summarizes the maximum power and the corresponding current density generated by the fuel cell for each FE concentration. The slope of the polarization curve is higher for the $1 \mathrm{M}$ acid, which indicates higher ohmic resistance due to low proton conductivity. The maximum power density reached with $1 \mathrm{M}$ sulfuric acid was $21.8 \mathrm{~mW} / \mathrm{cm}^{2}$ at a current density of $79 \mathrm{~mA} / \mathrm{cm}^{2}$. Increasing the concentration of sulfuric acid to $2 \mathrm{M}$ increased the power generated by the fuel cell by about $34 \%$. The performance of the cell using $2 \mathrm{M}$ acid gives comparable results to the $3 \mathrm{M}$ acid. However, at higher current densities, the $3 \mathrm{M}$ sulfuric acid results in the highest power density. The maximum power generated by the fuel cell using $3 \mathrm{M}$ sulfuric acid was $31.6 \mathrm{~mW} / \mathrm{cm}^{2}$ at a current density of 124 $\mathrm{mA} / \mathrm{cm}^{2}$, which only improved by approximately $8 \%$ when compared to $2 \mathrm{M}$ acid. On the other hand, a higher sulfuric acid concentration can increase the adsorption

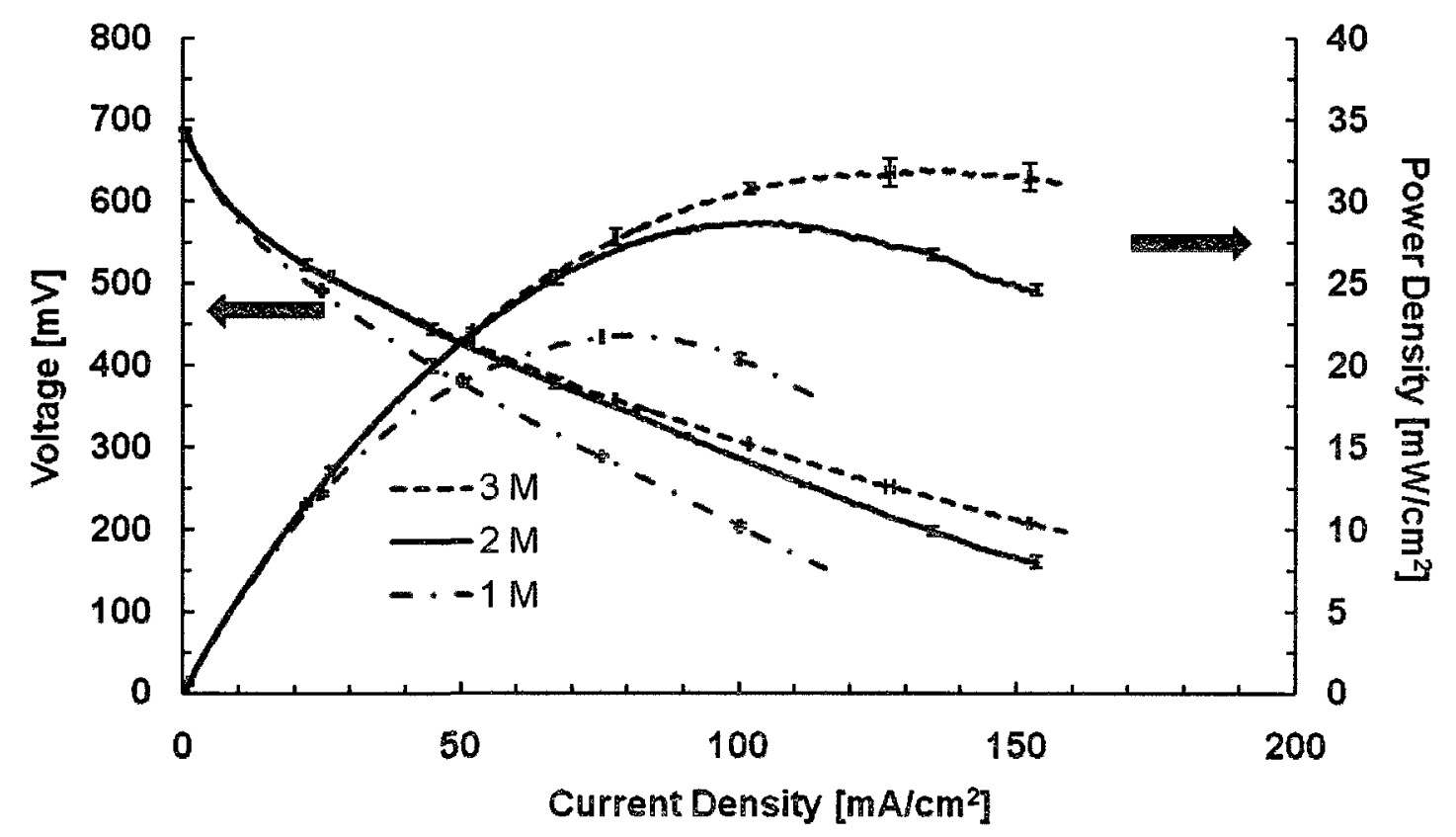

Type $1 \mathrm{MEA}, C_{m}=2 \mathrm{M}, \dot{m}_{m}=\dot{m}_{F E}=5 \mathrm{ml} / \mathrm{min}, F E-$ channel $=0.6 \mathrm{~mm}$, $T_{\text {cell }}=85^{\circ} \mathrm{C}$

Figure 28: Effects of FE concentration on performance 
of sulfate/bisulfate on the catalyst surface and degrade the catalyst faster [46]. Therefore, a $2 \mathrm{M}$ sulfuric acid was chosen to conduct the rest of the experiments.

Table 8: Effects of FE concentration on maximum power density

\begin{tabular}{|c|c|c|}
\hline Molarity [M] & Max Power density $\left[\mathrm{mW} / \mathrm{cm}^{2}\right]$ & Current density $\left[\mathrm{mA} / \mathrm{cm}^{2}\right]$ \\
\hline 1 & 21.8 & 78.9 \\
\hline 2 & 29.2 & 107.5 \\
\hline 3 & 31.6 & 124.2 \\
\hline
\end{tabular}

\subsubsection{Effects of flowing electrolyte flow rate}

The effects of the FE flow rate on the performance of the fuel cell has been shown in Figure 29, where $2 \mathrm{M}$ methanol and a $0.6 \mathrm{~mm} \mathrm{FE}$ channel were used. Figure 29 shows the polarization curves with respect to $\mathrm{FE}$ flow variations for $0,3,5,8$ and $10 \mathrm{ml} / \mathrm{min}$. It can be seen from this figure that the open circuit voltage for no FE flow is about $600 \mathrm{mV}$, but the OCV increases to 650 and $700 \mathrm{mV}$ for 3 and $5 \mathrm{ml} / \mathrm{min}$ of $\mathrm{FE}$ flow, respectively. The OCV changes minimally at higher flow rates. As discussed in Chapter 1, when no current is drawn from the cell (open circuit), reaction kinetic and methanol crossover losses are the only factors that contribute to the loss of voltage. Therefore, it can be concluded that the variations of the OCV with increasing of the FE flow rate is a result of the change in the amount of methanol crossover. This is also confirmed by looking at the power curves for different flow rates. Higher power densities have been achieved with higher flow rates, which is also due to less methanol crossover.

The maximum power density dependence on the FE flow rate was also studied for a $0.6 \mathrm{~mm} \mathrm{FE}$ channel. Figure 30 shows the results of this experiment. As was concluded from Figure 29, the maximum power density increased when increasing the 


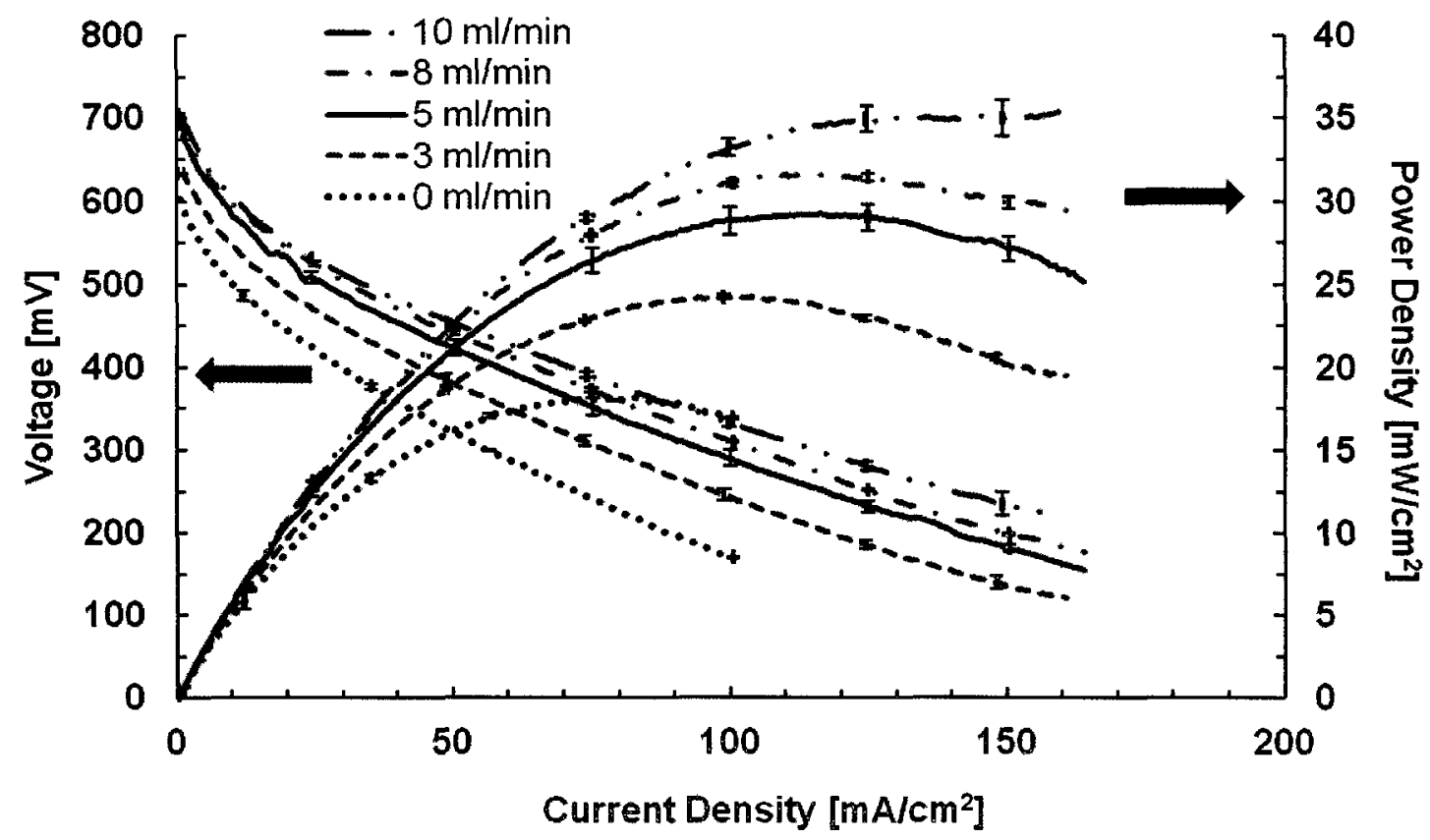

Type $1 \mathrm{MEA}, C_{m}=C_{F E}=2 \mathrm{M}, \dot{m}_{m}=5 \mathrm{ml} / \mathrm{min}, F E-$ channel $=0.6 \mathrm{~mm}$, $T_{\text {cell }}=85^{\circ} \mathrm{C}$

Figure 29: Effects of FE flow rate

flow rate. For $2 \mathrm{M}$ methanol, there was a $55 \%$ increase in the maximum power density after turning on the flowing electrolyte and adjusting the flow rate to $5 \mathrm{ml} / \mathrm{min}$. However, there was minimal difference between the maximum power densities for 8,10 and $13 \mathrm{ml} / \mathrm{min}$ flows, especially for $0.5 \mathrm{M}$ methanol. It can be concluded from these results that methanol crosses over to the cathode side where there is no FE flow and degrades the performance. However, as the FE flow rate increases, the amount of methanol that reaches the cathode decreases significantly. The asymptotic behavior observed in this figure shows that the maximum power density reaches a stabilized point even though the flow rate increases, which indicates that the optimum flow rate has been reached. 


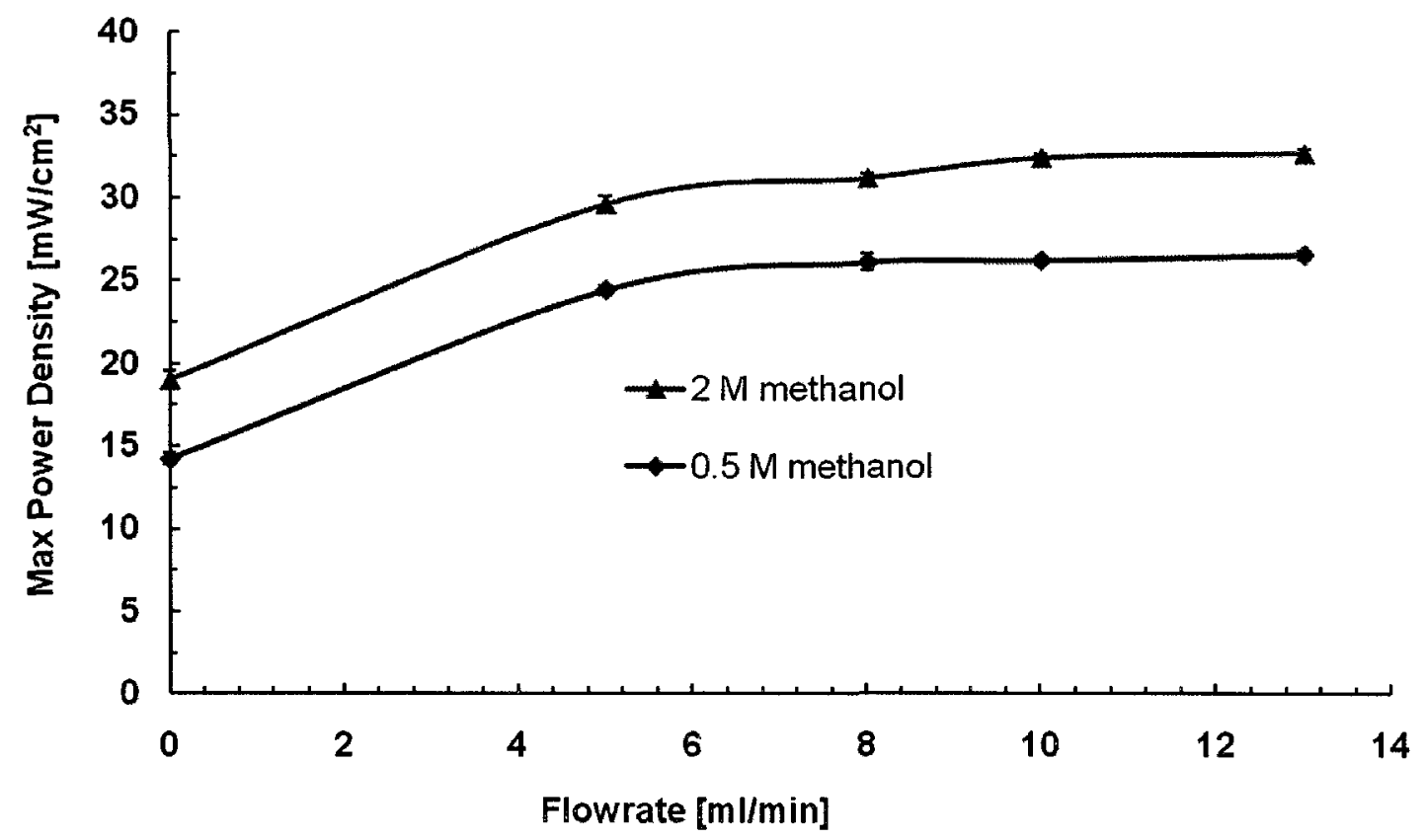

Type $1 \mathrm{MEA}, C_{F E}=2 \mathrm{M}, \dot{m}_{m}=5 \mathrm{ml} / \mathrm{min}, F E-$ channel $=0.6 \mathrm{~mm}, T_{\text {cell }}=85{ }^{\circ} \mathrm{C}$

Figure 30: Effects of FE flow rate on maximum power density

\subsubsection{Effects of flowing electrolyte channel thickness}

As discussed in Chapter 3, several flowing electrolyte channel thicknesses were tested. Figure 31 shows the performance of the fuel cell for different FE channels operating under the same conditions ( $2 \mathrm{M}$ methanol and $8 \mathrm{ml} / \mathrm{min} \mathrm{FE}$ flow rate). These results demonstrate that the OCV of the thicker channels (1.5 and $2.0 \mathrm{~mm}$ ) is approximately $700 \mathrm{mV}$ whereas for the $0.6 \mathrm{~mm}$ channel, is $680 \mathrm{mV}$. This indicates that methanol crossover removal is more effective with thicker channels.

Thicker channels, however, have more resistance due to longer electrode-toelectrode distance. By looking at the polarization curves that are shown in Figure 31 , it can also be concluded that the $2.0 \mathrm{~mm}$ channel has a much higher slope than the two other channels, which is an indication of higher ohmic resistance. Therefore, the maximum power density generated by the $2 \mathrm{~mm}$ channel is about 


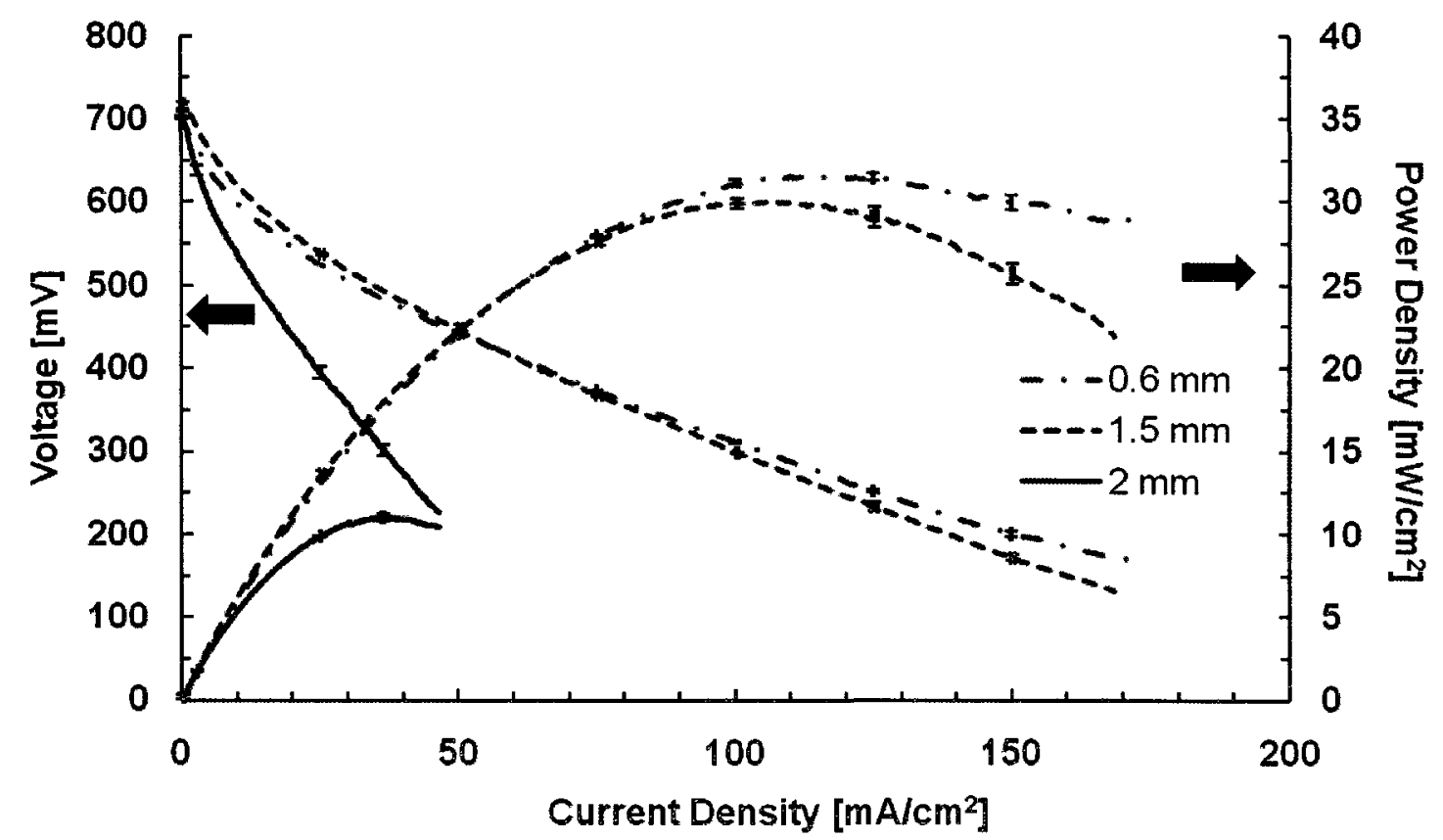

Type $1 \mathrm{MEA}, C_{m}=C_{F E}=2 \mathrm{M}, \dot{m}_{m}=5 \mathrm{ml} / \mathrm{min}, \dot{m}_{F E}=8 \mathrm{ml} / \mathrm{min}, T_{\text {cell }}=85{ }^{\circ} \mathrm{C}$

Figure 31: Effects of FE thickness on performance

$11 \mathrm{~mW} / \mathrm{cm}^{2}$ while 1.5 and $0.6 \mathrm{~mm}$ channels generate 30 and $31.6 \mathrm{~mW} / \mathrm{cm}^{2}$, respectively. The performance of the cell with the $1.5 \mathrm{~mm}$ channel is higher than the $0.6 \mathrm{~mm}$ channel for lower current densities, which indicates less methanol crossover.

Finally, with increasing current density, more methanol is consumed on the anode and less methanol is available to cross through the membrane. Therefore, an increase in the performance can be seen at higher current densities for the $0.6 \mathrm{~mm}$ channel, which is due to lower cell resistance as a result of lower electrode-to-electrode distance. Jayashree $e t$ al. also found that reducing the electrode-to-electrode distance resulted in an increase in the performance [45]. 


\subsubsection{Effects of flowing electrolyte pressure}

Variations of flowing electrolyte channel pressure were studied. For this study, the pressure was regulated using a needle valve. However, the pressure would fluctuate during the operation of the fuel cell. For a $0.6 \mathrm{~mm} \mathrm{FE}$ channel, increasing the pressure by more than 1 psi would block the flow. Therefore, a $1.5 \mathrm{~mm}$ channel was used to measure the maximum power generated by the fuel cell with respect to pressure variations for 5 and $8 \mathrm{ml} / \mathrm{min} \mathrm{FE}$ flow rates. These results are demonstrated in Figure 32. According to these findings, increasing the pressure of the FE channel reduces the power of the fuel cell for both flow rates. This may be a result of more water and sulfuric acid molecules crossing the cathode membrane and block the catalytic sites due to pressure gradient effects. Mass transfer resistance also has a positive correlation with pressure [52]. Therefore, increasing the pressure of the FE, provides more pressure to the electrodes and may increase the resistance of the fuel

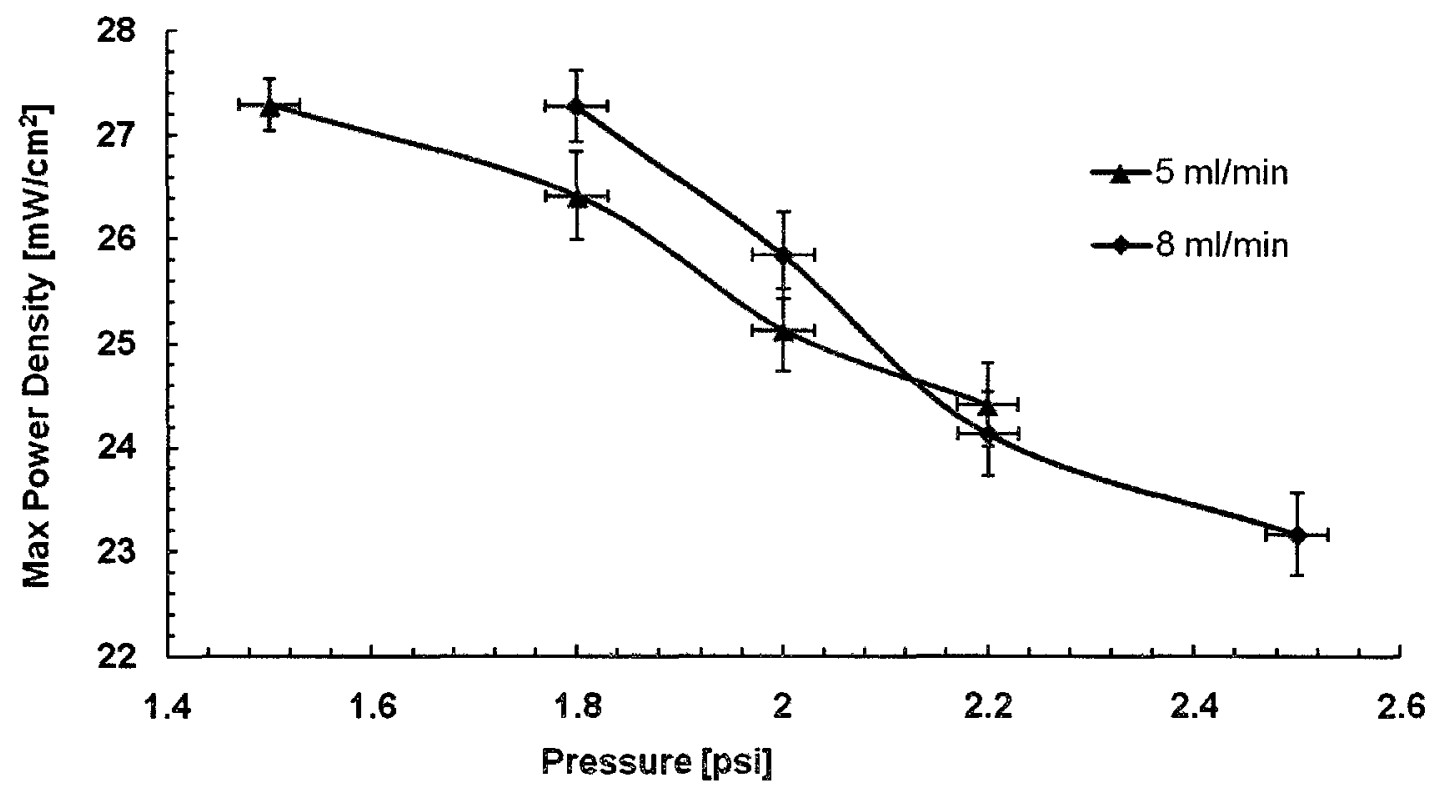

Type $1 \mathrm{MEA}, C_{m}=C_{F E}=2 \mathrm{M}, \dot{m}_{m}=5 \mathrm{ml} / \mathrm{min}, F E-$ channel $=1.5 \mathrm{~mm}$, $T_{\text {cell }}=85^{\circ} \mathrm{C}$

Figure 32: Effects of FE pressure on max power density 
cell. However, further investigation is required to confirm the reason for this behavior.

\subsection{Effects of methanol concentration}

The methanol concentration is one of the most important factors that affects the performance of the fuel cell. Figure 33 shows the polarization and power curves for 0.5, 2 and $4 \mathrm{M}$ methanol for the $0.6 \mathrm{~mm} \mathrm{FE}$ channel. By looking at the OCV in this figure, it can be concluded that a higher concentration of methanol results in lower OCV due to more methanol crossover (as discussed previously). As the current density increases, the voltage that is produced by the $0.5 \mathrm{M}$ methanol drops faster, while $2 \mathrm{M}$ methanol generates the highest power density of $34 \mathrm{~mW} / \mathrm{cm}^{2}$.

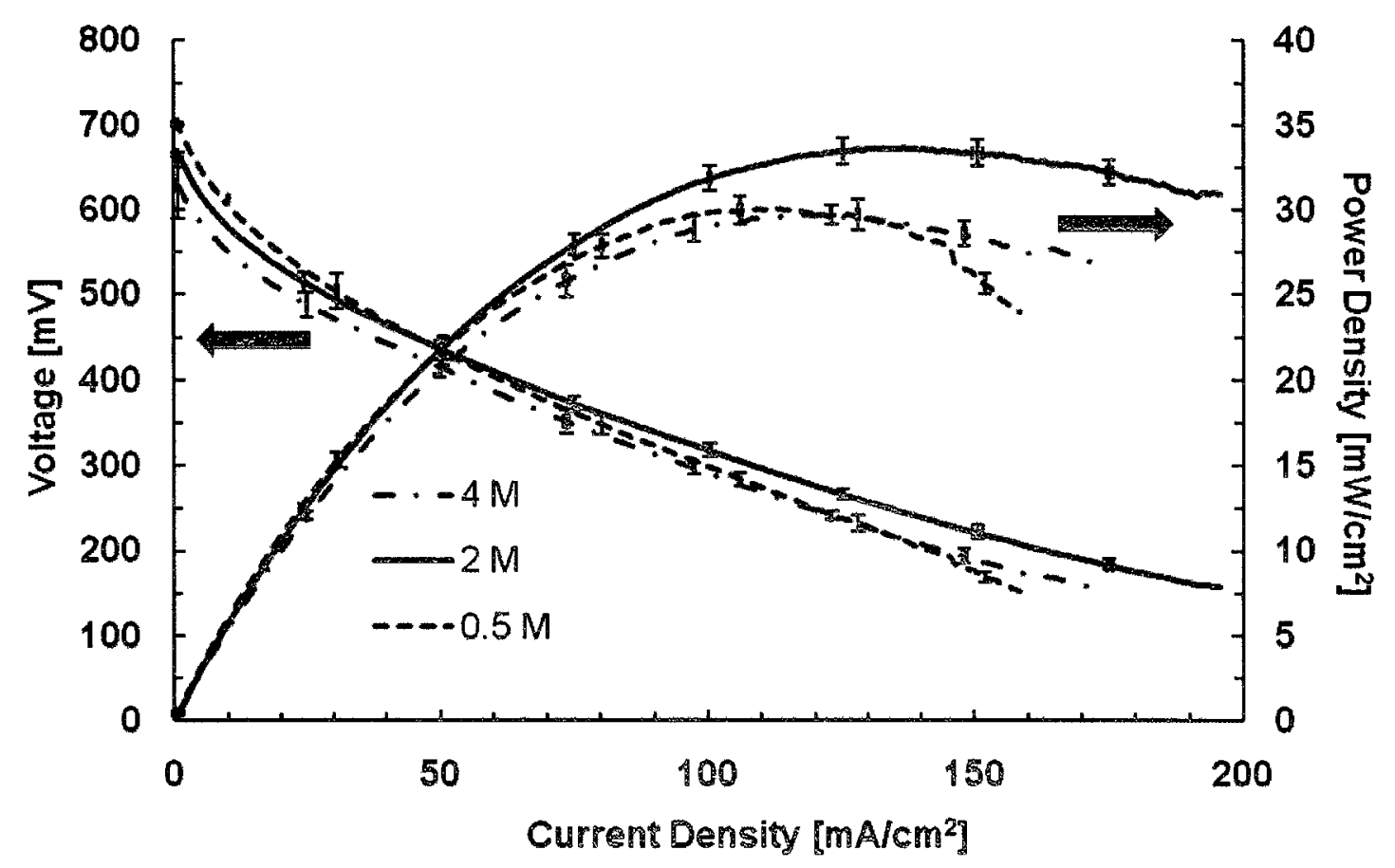

Type $1 \mathrm{MEA}, C_{F E}=2 \mathrm{M}, \dot{m}_{m}=\dot{m}_{F E}=5 \mathrm{ml} / \mathrm{min}, F E-$ channel $=0.6 \mathrm{~mm}$, $T_{\text {cell }}=85^{\circ} \mathrm{C}$

Figure 33: Effects of methanol concentration on performance 
Table 9 shows that for a regular DMFC, the performance of fuel cell operating with $0.5 \mathrm{M}$ methanol is higher. Other researches have also reached the conclusion that $2 \mathrm{M}$ methanol facilitates methanol crossover, which results in low performance. Therefore, it is evident that introducing the flowing electrolyte resulted in better performance of the fuel cell with a higher concentration of methanol, which is due to the removal of the crossed over methanol. A $4 \mathrm{M}$ methanol test was also conducted. It was observed that the performance was lower than $0.5 \mathrm{M}$ due to higher methanol crossover. Although at very higher current densities, 0.5 M methanol shows mass transport limitations.

\subsection{Effects of membrane thickness}

As discussed in Section 2.2.1, the thickness and equivalent weight of the membrane is one of the most contributing factors that determines the amount of methanol crossover. It was concluded that the thicker membrane allows less methanol to crossover. Table 9 shows the maximum power density generated by Type 1 and Type 2 MEA's for FE-DMFC with $0.6 \mathrm{FE}$ channel, as well as, a regular DMFC operating with $0.5 \mathrm{M}$ and $2 \mathrm{M}$ methanol. The Type $1 \mathrm{MEA}$ contains 117 and $212 \mathrm{Nafion}{ }^{\circledR}$ while the Type 2 has two sheets of Nafion ${ }^{\circledR} 212$.

Figures 34 and 35 show the performance of the fuel cell with different MEAs for 0.5 and $2 \mathrm{M}$ methanol solution, respectively. It can be concluded from Table 9 and Figure 34 that when comparing the two FE-DMFCs, the thinner MEA (Type 2 MEA) produces the best power density for less concentrated methanol. The maximum power density of $34.6 \mathrm{~mW} / \mathrm{cm}^{2}$ was achieved at a current density of $132.4 \mathrm{~mA} / \mathrm{cm}^{2}$.

Figure 35 demonstrates that the thicker MEA produced the best result when a higher concentration of methanol was used. In this case, the fuel cell generated a 


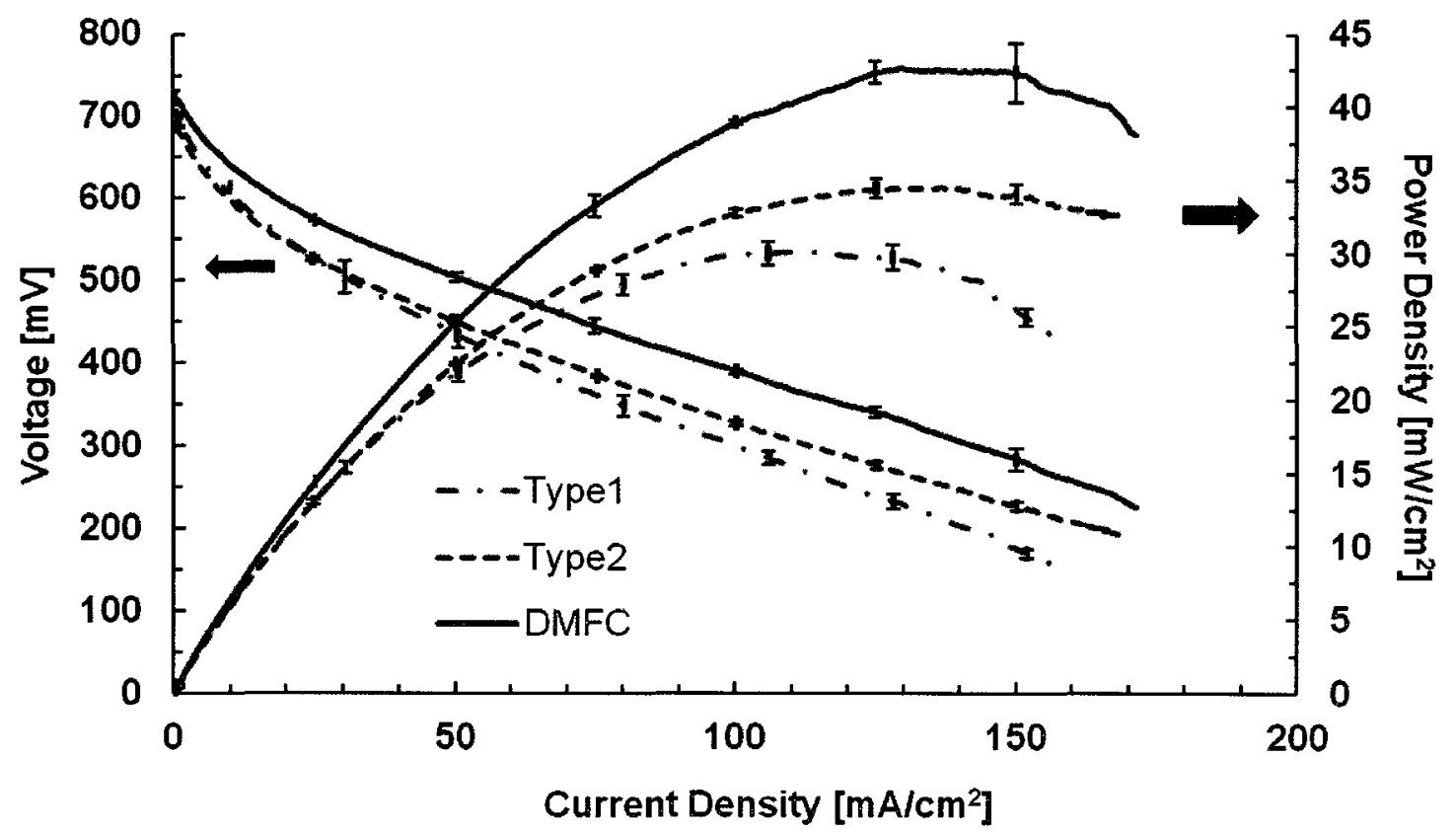

$$
\begin{gathered}
C_{m}=0.5 \mathrm{M}, C_{F E}=2 \mathrm{M}, \dot{m}_{m}=\dot{m}_{F E}=5 \mathrm{ml} / \mathrm{min}, F E-\text { channel }=0.6 \mathrm{~mm}, \\
T_{\text {cell }}=85^{\circ} \mathrm{C}
\end{gathered}
$$

Figure 34: Effects of MEA type on the performance using 0.5 M methanol

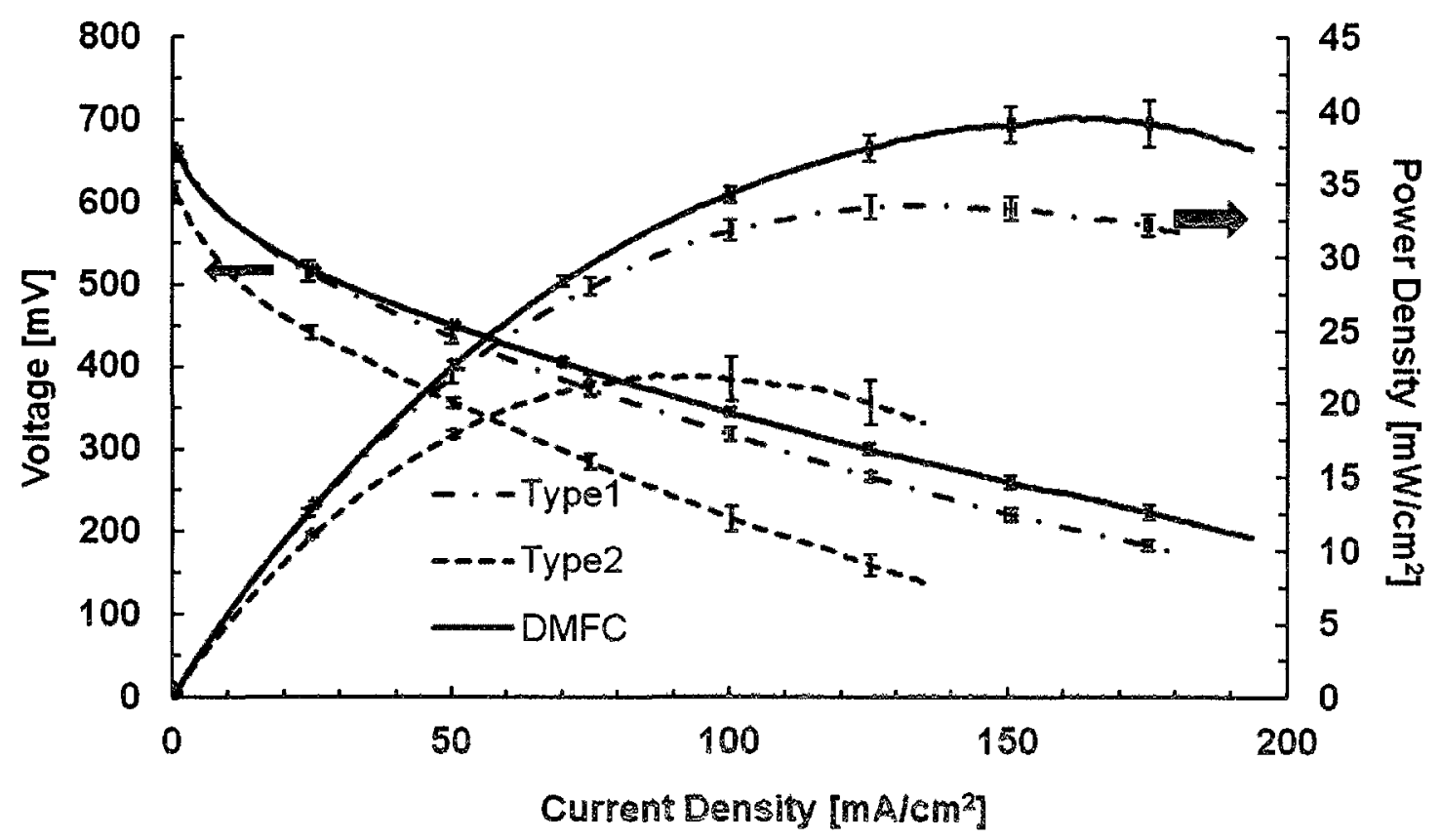

$C_{m}=C_{F E}=2 \mathrm{M}, \dot{m}_{m}=\dot{m}_{F E}=5 \mathrm{ml} / \mathrm{min}, \mathrm{FE}-$ channel $=0.6 \mathrm{~mm}, T_{\text {cell }}=85^{\circ} \mathrm{C}$

Figure 35: Effects of MEA type on the performance using $2 \mathrm{M}$ methanol 
Table 9: Comparison of the performance of FE-DMFC for different MEAs

\begin{tabular}{|l|l|l|l|}
\hline $\begin{array}{r}\text { Methanol } \\
\text { Concentration }\end{array}$ & $\begin{array}{l}\text { MEA } \\
\text { Type }\end{array}$ & $\begin{array}{l}\text { Max power density } \\
{\left[\mathrm{mW} / \mathrm{cm}^{2}\right]}\end{array}$ & $\begin{array}{l}\text { Current density } \\
{\left[\mathrm{mA} / \mathrm{cm}^{2}\right]}\end{array}$ \\
\hline \multirow{3}{*}{$0.5[\mathrm{M}]$} & Type1 & 30.1 & 112.9 \\
\cline { 2 - 4 } & Type2 & 34.6 & 132.4 \\
\cline { 2 - 4 } & DMFC & 42.7 & 129 \\
\hline \hline \multirow{3}{*}{$2[\mathrm{M}]$} & Type1 & 33.7 & 136.3 \\
\cline { 2 - 4 } & Type2 & 22 & 87.2 \\
\cline { 2 - 4 } & DMFC & 39.6 & 161.7 \\
\hline
\end{tabular}

maximum power density of $33.7 \mathrm{~mW} / \mathrm{cm}^{2}$ at a current density of $136.3 \mathrm{~mA} / \mathrm{cm}^{2}$. The regular DMFC has a similar OCV to Type 1 MEA, which indicates that the methanol crossover levels is similar. The OCV of the Type 2 MEA, however, is lower than the other two. Therefore, it can be concluded that the thinner MEA allows more methanol crossover while it has lower resistance and the thicker MEA generates a similar amount of power by facilitating less methanol crossover at higher initial concentration, but also contributes more to ohmic resistance. Comparing the two types of FE-DMFC membranes with a regular DMFC shows that lower resistance of the DMFC, results in higher power generated by the fuel cell.

\subsection{Temperature effects}

As previously discussed in Section 2.2.1, increasing the operating temperature of the fuel cell speeds up the kinetics of reaction, but also increases permeability of Nafion ${ }^{\circledR}$ to methanol. Figure 36 demonstrates the performance of the fuel cell for operating temperature of 65,75 and $85^{\circ} \mathrm{C}$ where $2 \mathrm{M}$ methanol and a $0.6 \mathrm{~mm} \mathrm{FE}$ channel were used. The OCV for all the three temperatures is about $700 \mathrm{mV}$. The fuel cell operating at $85{ }^{\circ} \mathrm{C}$ generates the highest power density, which is about 
$32.5 \mathrm{~mW} / \mathrm{cm}^{2}$. These behaviors indicate that the methanol crossover due to the higher temperature did not affect the performance of cell.

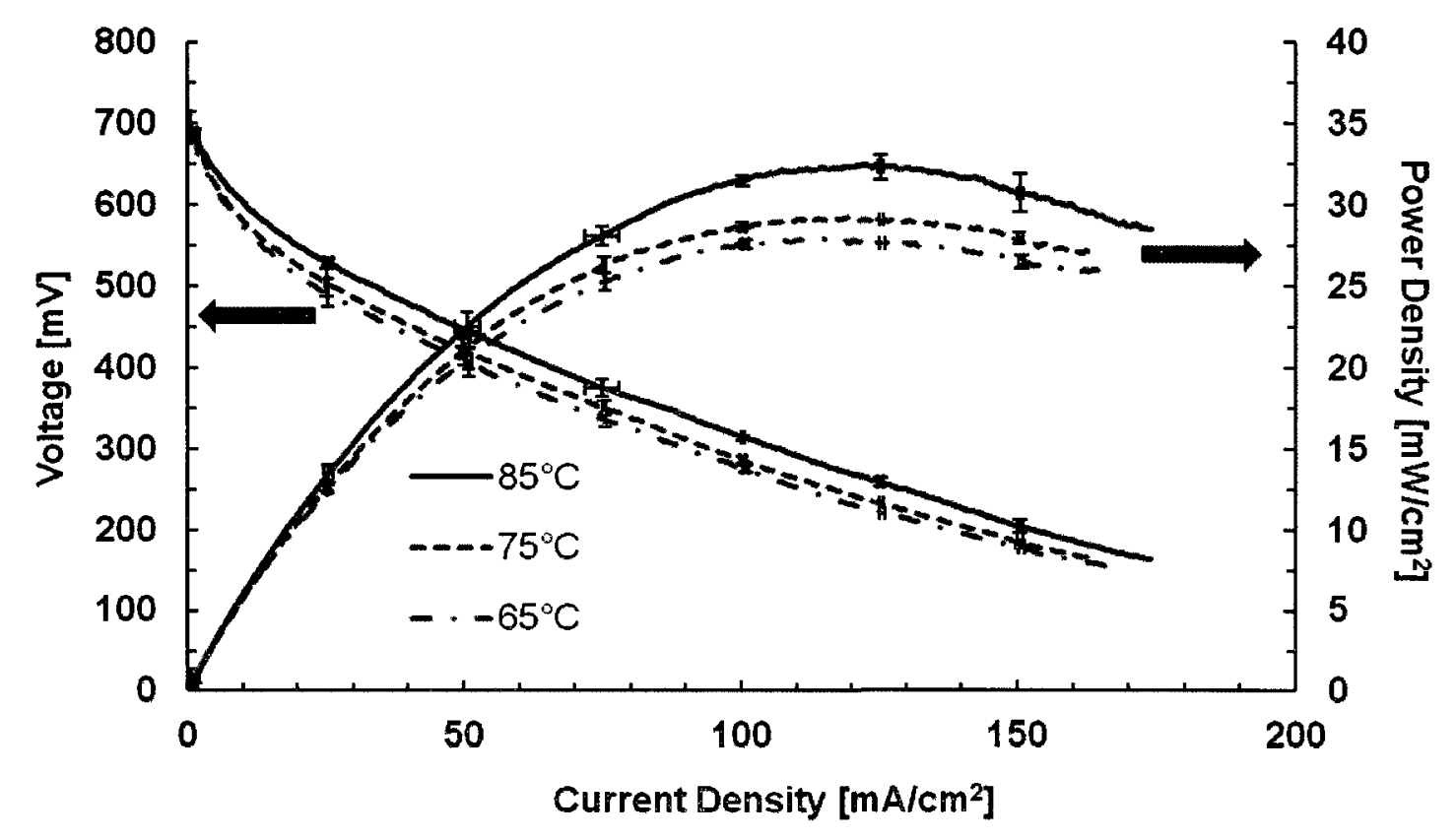

Type $1 \mathrm{MEA}, C_{m}=C_{F E}=2 \mathrm{M}, \dot{m}_{m}=\dot{m}_{F E}=5 \mathrm{ml} / \mathrm{min}, F E-$ channel $=0.6 \mathrm{~mm}$

Figure 36: Effects of cell operating temperature on fuel cell performance

The polarization curve shows that the activation drop reduced for increasing temperature, which was due to the improvement of kinetics of the electrodes [59]. Higher temperatures could not be tested during this study due to the degradation temperature limitations of the electrodes and Nafion ${ }^{\circledR}$. In 2010, Hollinger et al. reported the same pattern for direct methanol laminar fuel cell which also uses a circulating electrolyte [47]. Several other researchers also found similar results for regular DMFCs [30,59-61]. 


\subsection{Effects of methanol flow rate}

In order to find the optimum operating conditions, several methanol flow rates were tested. The result of these experiments are shown in Figure 37 for $2 \mathrm{M}$ methanol and a $0.6 \mathrm{~mm}$ FE channel. As shown in this graph, for the range of the selected flow rates, the methanol flow rate changes does not have a large effect on the performance of the fuel cell. Increasing the flow rate from 5 to $7 \mathrm{ml} / \mathrm{min}$ reduced the performance slightly, which is most likely due to more methanol crossover.

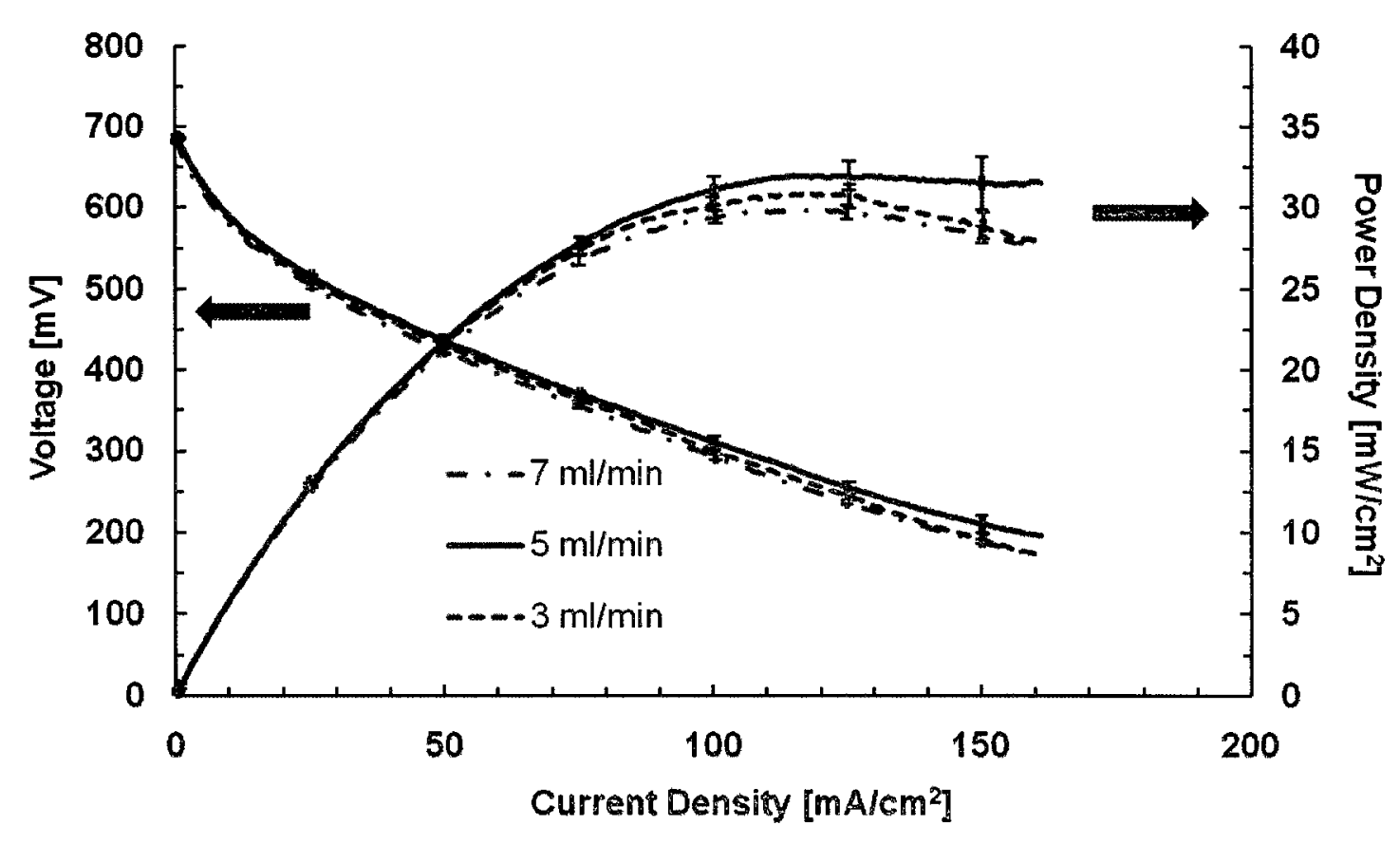

Figure 37: Effects of methanol flow rate

Scott et al. explains that in DMFCs, the anode flow rate influences the limiting current and polarization characteristics by changing the temperature at the anode and methanol concentration in the cell [62]. The loss of performance as a result of the higher methanol flow rate is due to the reduction of the mass transfer coefficient, which is due to the temperature changes at the catalyst layer [62]. They also explain that using low flow rates improved the conversion rate of methanol, which reduced 
the amount of methanol in the exhaust that needed to be recovered during practical fuel cell operations [62]. Several researchers have concluded, however, that changing the methanol flow rate has a significant effect on cell performance up to a point, but further increasing the flow rate has no effect $[59,61]$. It should be noted that in the case of this study, the variation of methanol flow rate was not extensive enough to provide considerable change in the performance.

It should be noted that the purpose of this study was to determine the effects of different operating conditions on the performance of a flowing electrolyte-direct methanol fuel cell. The total optimization of the fuel cell is beyond the scope of the current work. 


\section{Chapter 6}

\section{Conclusions and Recommendations}

The experimental results were shown and discussed in the previous chapter. In this chapter, the conclusion of the results, as well as, recommendations for future work are given.

\subsection{Contributions and conclusions}

This study contributed to the fuel cell field by demonstrating a unique design for the flowing electrolyte-direct methanol fuel cell. It was proven that the flowing electrolyte can remove methanol crossover and that using a hydrophilic microporous polyethylene material as the FE channel improved the performance of the FE-DMFC. Two different Nafion ${ }^{\circledR}$ thicknesses were successfully tested and a preferred MEA combination was found. Finally, the results from this study were presented and published at the ASME Energy Sustainability and Fuel Cell Science Conference in August 2011 [63]. This work will aid in the designing and development of a fuel cell stack for future studies.

The following conclusions have been drawn from this study:

- An experimental set up was designed, developed and successfully operated. 
- A single cell FE-DMFC have been constructed and tested successfully.

- It was shown that the flowing electrolyte improves the performance of a direct methanol fuel cell by removing the crossed over methanol before it reaches the cathode.

- The most advantageous electrolyte concentration was $2 \mathrm{M}$ sulfuric acid.

- Increasing the flowing electrolyte flow rate improved the performance of the fuel cell.

- It was also concluded that although a thicker FE channel provides more adequate conditions for washing off the methanol, it also increases the internal resistance of the fuel cell. Therefore, a $0.6 \mathrm{~mm}$ channel was found to give the highest power density.

- Increasing the FE channel pressure was also found to decrease the performance.

- The performance of the fuel cell with respect to methanol concentration depends on the thickness of the Nafion ${ }^{\circledR}$ used in a MEA. For MEAs that use a thicker Nafion ${ }^{\circledR}, 2 \mathrm{M}$ methanol with a $0.6 \mathrm{~mm}$ FE channel gave the maximum power density. For MEAs with a thinner membrane, $0.5 \mathrm{M}$ methanol proved to be advantageous.

- Higher operating temperature (up to $85^{\circ} \mathrm{C}$ ) improved the performance of the fuel cell.

- Changes of air pressure and flow rate did not alter the fuel cell output, as long as air was provided in excess.

- Regulating the pressure of methanol was not possible with the current equipment due to the constant pressure fluctuation, which is the result of bubbles generated within the anode feed. 


\subsection{Recommendations}

The following recommendations have been made for future research on a single cell-flowing electrolyte direct methanol fuel cell:

- As discussed, the flowing electrolyte successfully minimized the crossover methanol and improved the performance. In order to optimize the performance of the fuel cell, it would be beneficial to measure the amount of methanol that is removed by the flowing electrolyte and also the concentration of methanol that reaches the cathode.

- The anode and cathode polarization curve could be obtained separately by using a reference electrode. This would aid in understanding the performance of the individual electrodes.

- Measuring the internal resistance of the single cell FE-DMFC would also help to identify the components that contributed the most to the ohmic losses.

- High internal resistance is one the major problems with the FE-DMFC since two Nafion ${ }^{\circledR}$ sheets and a FE channel is used. Eliminating at least one of the membranes could result in significant performance improvement. Design changes should be made and also suitable membranes should be identified to reduce the resistance of the cell considerably. Similar design to laminar flow fuel cells could be adapted, where liquid-liquid interface provides the required ionic conductance [44].

- The FE channel material could also be studied in order to find a material that decreases the ion transport resistance and also reduces the pressure drop in the FE channel. 
- A technique should be identified to prevent the delamination of the GDL from Nafion ${ }^{\circledR}$, in order to decrease the ohmic losses.

- The effect of humidity and temperature of air should be studied as well as the potential use of pure oxygen to replace air.

- Sulfuric acid is a very corrosive chemical. Identifying other electrolytes that provide similar or better conductivity and that are also compatible with other components of the fuel cell (such as the electrodes and the membrane) would be beneficial. For example, formic acid could be used to replace sulfuric acid. However, the conductivity of formic acid is much lower than sulfuric acid. Therefore, methods such as the addition of sodium sulfate salt can be pursued in order to increase the conductivity of the electrolyte.

- It was observed that the performance of the fuel cell increases rapidly before stabilizing at a lower performance. Therefore, other types of flowing electrolytes such as pulsating flow should be studied.

- Durability and longevity tests should be done in order to understand the corrosive effect of sulfuric acid on the catalysts.

- In this study, fresh electrolyte was used for all of the experiments. However, studying effects of circulating the electrolyte should be conducted for long-term operations of the fuel cell.

- Finally, the flowing electrolyte concept could be applied to other fuel cells such as PEMFCs or direct ethanol fuel cells (DEFCs). It should be noted that Pt is used as the catalyst on both of the anode and cathode electrodes in a PEMFC, while the catalyst that could be used at the anode in a DEFC is highly under investigation $[64,65]$. 


\section{List of References}

[1] R. O'Hayre, S. Cha, and W. Colella, Fuel Cell Fundamentals. John Wiley \& Sons, INC., 2006.

[2] K. Mauritz and R. Moore, "State of understanding of nafion," ChemInForm, vol. 104, pp. 4535-4585, 2004.

[3] G. Lu and C. Wang, "Electrochemical and flow characterization of a direct methanol fuel cell," Journal of Power Sources, vol. 134, pp. 33-40, 2004.

[4] V. Bagostsky, Fuel Cells: Problems and Solutions. Wiley, 2009.

[5] K. Kordesch and S. G., Fuel Cells and Their Applications. VCH, 1996.

[6] C. Spiegel, Modeling and Simulation Using MATLAB. Academic Press - Elsevier, 2008.

[7] C. Spiegel, Designing \& Building Fuel Cells. McGraw Hill, 2007.

[8] N. DeLuca, Nafion blend membranes for the direct methanol fuel cell. $\mathrm{PhD}$ thesis, Drexel University, February 2008.

[9] X. Li, Principles of Fuel Cells. Taylor \& Francis, 2006.

[10] B. Holland, J. Zhua, and L. Jamet, "Fuel cell technology and application," 2007.

[11] H. Liu and J. Zhang, Electrocatalysis of Direct Methanol Fuel Cells: From Fundamentals to Applications. Wiley-VCH Verlag GmbH \& co. KGaA, 2009.

[12] R. Dillon, S. Srinivasan, A. Arico, and V. Antonucci, "International activities in dmfc r\&d: status of technologies and potential applications," in Fuel Cells Compendium (N.Brandon and D. Thompsett, eds.), Elsevier, 2005.

[13] X. Zhang, Preperation and characterization of proton exchange membranes for direct methanol fuel cells. PhD thesis, Department of Chemical Engineering, Iniversitat Rovira i Virgili, September 2005. 
[14] V. Oliveira, C. Rangel, and A. Pino, "Modelling and experimental studies on a direct methanol fuel cell working under low methanol crossover and high methanol concentrations," International Journal of Hydrogen, vol. 34, pp. 6443-$6451,2009$.

[15] P. Kauranen and E. Skou, "Methanol permeability in perfluorosulfonate proton exchange membranes at elevated temperatures," Journal of Applied Electrochemistry, vol. 26, pp. 909-917, 1996.

[16] J. Villaluenga, B. Seoane, V. Barragn, and C. Ruiz-Bauz, "Permeation of electrolyte watermethanol solutions through a nafion membrane," Journal of Colloid and Interface Science, vol. 268, pp. 476-481, 2003.

[17] T. Tschinder, T. Schaffer, S. Fraser, and V. Hacker, "Electro-osmotic drag of methanol in proton exchange membranes," Journal of Applied Electrochemistry, vol. 37, pp. 711-716, 2007.

[18] J. Ling and O. Savadogo, "Comparison of methanol crossover among four types of nafion membranes," Journal of The Electrochemical Society, vol. 151, pp. A1604A1610, 2004.

[19] K. Kordesch, "Direct methanol fuel cell with circulating electrolyte," US Patent, 2003.

[20] K. Kordesch, V. Hacker, and U. Bachhiesl, "Direct methanol-air fuel cells with membranes plus circulating electrolyte," Journal of Power Sources, vol. 96, pp. 200-203, 2001.

[21] E. Kjeang, J. Goldak, G. M.R., J. Gu, D. James, and K. Kordesch, "A parametric study of methanol crossover in a flowing electrolyte-direct methanol fuel cell," Journal of Power Sources, vol. 153, pp. 90-99, 2006.

[22] A. Arico, P. Creti, V. Baglio, E. Modica, and V. Antonucci, "Influence of flow field design on the performance of a direct methanol fuel cell," Chemical Engineering Journal, vol. 91, pp. 202-209, 2000.

[23] M. Kim, W. Lim, M. Lee, and I. Moon, "3-dimensional cfd simulation modeling for optimal flow field dsign of direct methanol fuel cell bipolar plate," in ICROSSICE International Joint Conference, Aug 2009.

[24] H. Yang and T. Zhao, "Effect of anode flow field design on the performance of liquid feed direct methanol fuel cells," Electrochimica Acta, vol. 50, pp. 3243$3252,2005$. 
[25] V. Oliveira, C. Rangel, and A. Pino, "Effect of anode and cathode flow field design on the performance of a direct methanol fuel cell," Chemical Engineering Journal, vol. 157, pp. 174-180, 2010.

[26] A. Aricoa, S. Srinivasan, and V. Antonuccia, "Dmfes: From fundamental aspects to technology development," Fuel Cells, vol. 1, pp. 133-161, 2001.

[27] F. Kalhammer, P. Prokopius, V. Roan, and G. Voecks, "Status and prospects of fuel cells as automobile engines," tech. rep., Fuel Cell Technical Advisory Panel, July 1998.

[28] M. Hogarth and T. Ralph, "Catalysis for low temperature fuel cells," PLATINUM METALS REVIEW, vol. 46, pp. 146-164, 2004.

[29] N. Vladimir, M. Jonathan, W. Haijiang, and Z. Jiujun, "A review of polymer electrolyte membranes for direct methanol fuel cells," Jouarnal of Power Sources, vol. 169, pp. 221-238, 2007.

[30] D. Jung, C. Lee, C. Kim, and D. Shin, "Performance of a direct methanol polymer electrolyte fuel cell," Jouarnal of Power Sources, vol. 71, pp. 169-173, 1998.

[31] S. Narayanan, A. Kinder, B. Jeffries-Nakamura, H. F. W. Chun, M. Smart, T. Valdez, S. Surampudi, and G. Halpert, "Recent advances in pem liquid-feed direct methanol fuel cells," Battery Conference on Applications and Advances, vol. 11, pp. 113-122, 1996.

[32] D. Hallinan and Y. Elabd, "Diffusion and sorption of methanol and water in nafion using time-resolved fourier transform infrared-attenuated total reflectance spectroscopy," Journal of Physical Chemistry B., vol. 111, pp. 13221-13230, 2007.

[33] V. Mehta and J. Cooper, "Review and analysis of pem fuel cell design and manufacturing," Journal of Power Sources, vol. 114, pp. 32-53, 2003.

[34] P. Argyropoulos, K. Scott, and W. Taama, "Gas evolution and power performance in direct methanol fuel cells," Journal of Applied Electrochemistry, vol. 29, pp. 661-669, 1999.

[35] A. Oedegaard, C. Hebling, A. Schmitz, S. Moller-Holst, and R. Tunold, "Influence of diffusion layer properties on low temperature dmfc," Journal of Power Sources, vol. 127, p. 187196, 2004. 
[36] C. Song and P. P. up, "Effect of hot pressing on the performance of direct methanol fuel cells," Jouarnal of Applied Electrochemistry, vol. 34, pp. 1065$1070,2004$.

[37] T. Frey and M. Linardi, "Effects of membrane electrode assembly preparation on the polymer electrolyte membrane fuel cell performance," Electrochimca Acta, vol. 50, p. 99, 2004.

[38] M. Wilson and S. Gottesfeld, "Thin-film catalyst layers for polymer electrolyte fuel cell electrodes," Jouarnal of Applied Electrochemistry, vol. 22, pp. 1-7, 1992.

[39] M. Wilson and S. Gottesfeld, "High performance catalyzed membranes of ultralow pt loadings for polymer electrolyte fuel cells," Jouarnal of Electrochemical Society, vol. 139, pp. L28-L30, 1992.

[40] T. Matsubayashi, A. H. S. Taniguchi, Y. Miyake, and T. Saito, "Development of high performance electrode for pefc," proceedings of the Fuel Cells, pp. 581-584, 1994.

[41] A. Kuver, I. Vogel, and W. Vielstich, "Distinct performance evaluation of a direct methanol spe fuel cell. a new method using a dynamic hydrogen reference electrode," Journal of Power Sources, vol. 52, pp. 77-80, 1994.

[42] T. Zawodzinski Jr., T. Springer, F. Uribe, and S. Gottesfeld, "Characterization of polymer electrolytes for fuel cell applications," Solid State Ionics, vol. 60, pp. 199-211, 1993.

[43] J. Zhang, G. Yin, Z. Wang, Q. Lai, and K. Cai, "Effects of hot pressing conditions on the performances of meas for direct methanol fuel cells," Journal of Power Sources, vol. 165, pp. 73-81, 2007.

[44] E. Choban, S. J.S., L. Gancs, A. Wieckowski, and P. Kenis, "Membraneless laminar flow-based micro fuel cells operating in alkaline, acidic, and acidic/alkaline media," Electrochemica Acta, vol. 50, pp. 5390-5398, 2005.

[45] R. Jayashree, F. C. S.K. Yoon, P. Lopez-Montesinos, D. Natarajan, L. Markoski, and P. Kenis, "On the performance of membraneless laminar flow-based fuel cells," Journal of Power Sources, vol. 195, pp. 3569-3578, 2010.

[46] R. Jayashree, M. Mitchell, D. Natarajan, L. Markoski, and P. Kenis, "Microfluidic hydrogen fuel cell with a liquid electrolyte," The American Chemical Society Journal of Surfaces and Colloids, vol. 23, no. 13, 2007. 
[47] A. Hollinger, R. Maloney, R. Jayashree, D. Natarajan, and L. M. P.J.A., "Nanoprous separator and low fuel concentration to minimize crossover in direct methanol fuel cells," Journal of Power Sources, vol. 195, pp. 3525-2528, 2010.

[48] "Ohio carbon blank ocb ar-8 edm grade graphite," http://www.matweb.com/search/datasheet.aspx? matguid=43cdb72479cd44198ec fb39777026d648Gckck=1, vistied 16, June, 2011.

[49] A. Therdthianwong, P. Manomayidthikarn, and S. Therdthianwong, "Investigation of membrane electrode assembly (mea) hot-pressing parameters for proton exchange membrane fuel cell," Journal of Energy, vol. 32, pp. 2401-2411, 2007.

[50] L. Tse, Membrane electrode assembly design for power design enhancement of direct methanol fuel cells. $\mathrm{PhD}$ thesis, Georgia Institute of Technology, Aug, 2006 .

[51] J. Zhang, G. Yin, Z. Wang, Q. Lai, and K. Cai, "Effects of hot pressing conditions on the performance of meas for direct methanol fuel cells," Journal of Power Sources, vol. 165, pp. 73-81, 2007.

[52] Y. Zhu, C. Liu, J. Liang, and L. Wang, "Investigation of the effects of compression pressure on direct methanol fuel cell," Journal of Power sources, vol. 196, pp. 264-269, 2011.

[53] S. Kline and F. McClintock, "Describing uncertainties in single sample experiments," Mechanical Engineering, vol. 75, pp. 3-8, 1953.

[54] R. Moffat, "Describing the uncertainties in experimental results," Experimental Thermal and Fluid Science, vol. 1, pp. 3-17, 1988.

[55] T. A. S. of Mechanical Engineers, "Measurement uncercainty: Instruments and apparatus," 1985.

[56] J. Koryta, J. Dvorak, and L. Kavan, Principles of Electrochemistry. Wiley, 1993.

[57] M. Wright, An Introduction to Aqueous Electrolyte Solutions. Wiley, 2007.

[58] H. Darling, "Conductivity of sulfuric acid solutions," Journal of Chemical and Engineering Data, vol. 9, pp. 421-426, 1964.

[59] J. Ge and H. Liu, "Experimental studies of a direct methanol fuel cell," Journal of Power Sources, vol. 142, pp. 56-69, 2005. 
[60] K. Scott, W. Taama, P. Argyropoulos, and K. Sundmacher, "The impact of mass transport and methanol crossover on the direct methanol fuel cell," Journal of Power Sources, vol. 83, pp. 204-216, 1999.

[61] S. Seo and C. Lee, "Effect of operating parameters on the direct methanol fuel cell using air or oxygen as an oxidant gas," Journal of Power Sources, vol. 83, pp. 204-216, 1999.

[62] K. Scott, W. Taama, P. Argyropoulos, and K. Sundmacher, "Limiting current behaviour of the direct methanol fuel cell," Journal of Power Sources, vol. 83, pp. 204-216, 1999.

[63] N. Sabet-Sharghi, C. Cruickshank, and E. Matida, "Experimental analysis of a single cell-flowing electrolyte direct methanol fuel cel," in Proceedings of ESFuelCell2011, ASME, Aug 2011.

[64] E. Antolini, "Catalysts for direct ethanol fuel cells," Journal of Power sources, vol. 170, pp. 1-12, 2007.

[65] C. Xu, P. K. Shen, and Y. Liu, "Ethanol electrooxidation on pt/c and pd/c catalysts promoted with oxide," Journal of Power sources, vol. 164, pp. 527$531,2007$.

[66] S. Maharudrayya, S. Jayanti, and A. Deshpande, "Pressure losses in laminar flow through serpentine channels in fuel cell stacks," Journal of Power sources, vol. 138, 2004. 


\section{Appendix A}

\section{CFD Analysis of the Parallel Serpentine}

\section{Channels}

As mentioned in Chapter 1 , the flow of methanol solution in the reactant distributor channels was simulated using CFX 12.0 (Ansys Inc., Canonsburg, Pennsylvania, U.S.A). These channels are small $(1.5 \mathrm{~mm} \times 1.5 \mathrm{~mm})$ and the flow is laminar ( $R e>2100)$. Therefore, obtaining pressure drop would need special care since the loss coefficient in laminar flow depends strongly on the Reynolds number. Diluted methanol is generally used in DMFC which has a density of $791 \mathrm{~kg} / \mathrm{m}^{3}$. However, water was used for these simulations. It was assumed that the methanol solution has similar properties to water.

\section{A.1 Method}

\section{A.1.1 Theory}

Due to the small size of these channels, gathering experimental data was difficult. In this study, the flow analysis was based on CFD simulations in which the fundamental governing equations, such as the conservation of mass and momentum for an incompressible isothermal flow, are solved numerically. The governing equations are 
non-linear and second order partial differential equations, which are converted to a set of non-linear algebraic equations after discretization. These linearized algebraic equations are then solved simultaneously using iterative methods. The velocity at the inlet is assumed to be normal, and also a no-slip condition was applied at the walls. Assuming incompressibility, the governing equations are:

Mass balance equation:

$$
\frac{\partial\left(U_{i}\right)}{\partial x_{i}}=0
$$

Momentum balance equation:

$$
\frac{\partial\left(U_{j} U_{i}\right)}{\partial x_{i}}=-\frac{1}{\rho} \frac{\partial P}{\partial x_{i}}+\frac{\partial}{\partial x_{i}}\left(v \frac{\partial\left(U_{i}\right)}{\partial x_{j}}\right) \quad \text { for } \quad i=1,2,3
$$

where $U_{i}$ is the component of velocity in $i$-direction, $P$ is the static pressure, $\rho$ is the fluid density and $v$ is the fluid kinematic viscosity.

As shown in Figure 39, the geometry involves $90^{\circ}$ and $180^{\circ}$ bends in a duct of rectangular cross section. Therefore, the simulations were carried for a square bend with a curvature ratio $\mathrm{C}$,

$$
C=\frac{R_{c}}{D_{h}}
$$

where $R_{c}$ is the mean radius of the bend and $D_{h}$ is the hydraulic diameter. The $D_{h}$ can be calculated using Equation 18,

$$
D_{h}=\frac{4 w h}{2(w+h)}
$$

where $w$ and $h$ are the width and depth of the channel, respectively.

When considering the pressure variation in the upstream and downstream sections of the duct, it is important to note that there is a net pressure drop as the flow 
goes through the bend. Figure 38 illustrates the pressure variation where $\Delta P_{1}$ is the pressure loss in the straight pipe between points $\mathrm{A}$ and $\mathrm{F}$ in the absence of a bend, $\Delta P_{2}$ is the pressure loss that is added due to skin friction of the straightened length of the bend region and $\Delta P_{3}$ is the pressure loss associated with wake friction due to the bend [66]. Therefore, the pressure-loss coefficient $\left(K_{b}\right)$ can be defined using Equation 19.

$$
K_{b}=\frac{\Delta P_{2}+\Delta P_{3}}{\frac{1}{2 \rho V^{2}}}
$$

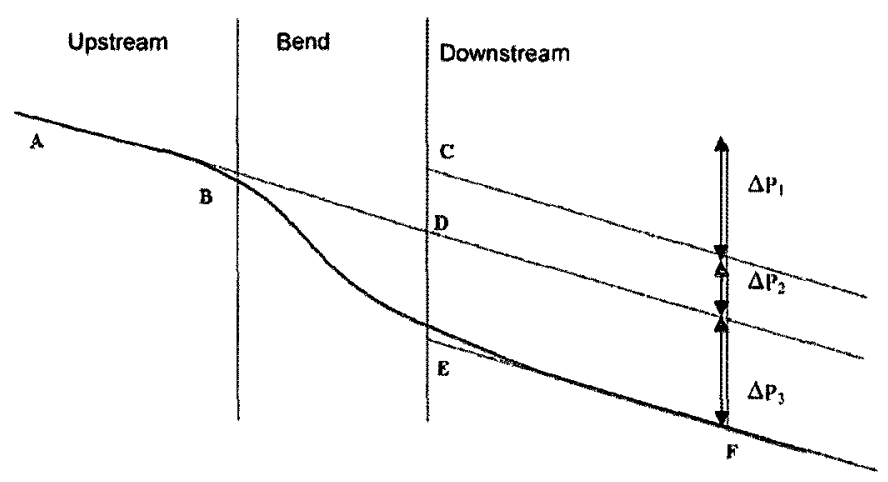

Figure 38: Schematic variation of pressure in duct with bend

The Reynolds number can be calculated from Equation 20.

$$
R e=\frac{\rho U D_{h}}{\mu}
$$

The simulation was carried out for several body spaces in order to determine the most suitable grid size and the corresponding Reynolds number for a specific performance. A residual reduction factor of $10^{-8}$ for the mass conservation equation was used to monitor the convergence iteration scheme. 


\section{A.2 Results}

\section{A.2.1 Meshing}

An unstructured CFX mesh with a $0.18 \mathrm{~mm}$ body spacing was selected. Table 10 includes the mesh statistics and Figure 39 illustrates the meshed geometry.

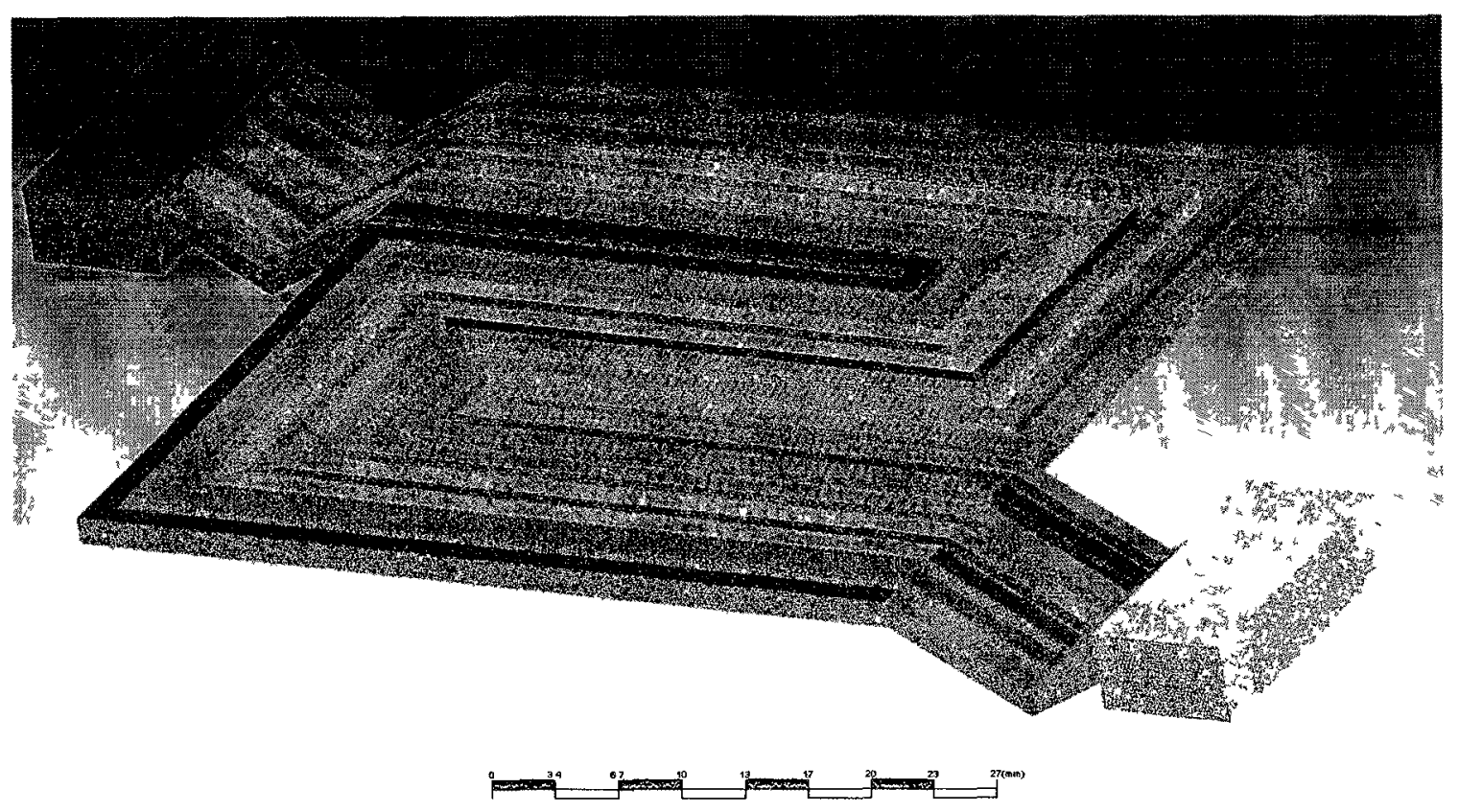

Figure 39: Meshed Channels for a body spacing $=0.18 \mathrm{~mm}$

Table 10: Mesh statistics for a $0.18 \mathrm{~mm}$ body spacing

\begin{tabular}{|c|c|}
\hline Total number of nodes & 1127815 \\
\hline Total number of tetrahedra & 5921486 \\
\hline Total number of pyramids & 0 \\
\hline Total number of prisms & 0 \\
\hline Total number of elements & $5,921,486$ \\
\hline
\end{tabular}




\section{A.2.2 Verifying results}

For laminar flow, the CFX calculation does not introduce any empiricism in the fundamental equation. Grid convergence analysis was used to verifying the data. This was done since discretization error depends on the grid density and to ensure grid independence.

Four different body spacing were used and compared in Table 11. For values of $0.18 \mathrm{~mm}$ and $0.15 \mathrm{~mm}$ body spacing, it can be concluded that $0.18 \mathrm{~mm}$ is very close to the finer mesh. However, the simulation runs faster with less memory allocation due to less number of elements. Therefore, $0.18 \mathrm{~mm}$ was chosen for further analysis.

Table 11: Summary of grid convergence analysis

\begin{tabular}{|l|l|l|l|l|l|}
\hline $\begin{array}{l}\text { Body spac- } \\
\text { ing }[\mathrm{mm}]\end{array}$ & $\begin{array}{l}\text { Number of } \\
\text { elements }\end{array}$ & $\begin{array}{l}V_{\min } \\
{[\mathrm{mm} / \mathrm{s}]}\end{array}$ & $\begin{array}{l}V_{\max } \\
{[\mathrm{mm} / \mathrm{s}]}\end{array}$ & $P_{\min }[\mathrm{Pa}]$ & $P_{\max }[\mathrm{Pa}]$ \\
\hline 0.25 & $2,313,835$ & $1.506 \mathrm{e}-8$ & 6.091 & 0.9996 & 5.748 \\
\hline 0.20 & $4,330,606$ & $4.40 \mathrm{e}-9$ & 6.286 & 0.9997 & 6.03 \\
\hline 0.18 & $5,921,486$ & $6.22 \mathrm{e}-9$ & 6.324 & 0.9997 & 6.137 \\
\hline 0.15 & $10,310,401$ & $6.23 \mathrm{e}-9$ & 6.324 & 0.9997 & 6.137 \\
\hline
\end{tabular}

\section{A.2.3 Different Reynolds numbers}

The methanol can flow at different speeds in the channels. Table 12 summarizes several flow rates and the Reynolds number at the inlet. Table 13 presents the pressure difference between the beginning and the end of the channel versus the volumetric flow rate. As shown in this table, that the pressure drop increases with increasing flow rate. This suggests that a lower flow rate and therefore, smaller Reynolds number, will result in less pressure drop. 
Table 12: Summary of Variables for different Reynold numbers

\begin{tabular}{|l|l|l|l|l|l|l|}
\hline $\begin{array}{l}\text { Flow rate } \\
(\mathrm{ml} / \mathrm{min})\end{array}$ & $\begin{array}{l}\text { Velocity } \\
(\mathrm{mm} / \mathrm{s})\end{array}$ & $\begin{array}{l}\text { Reynolds } \\
\text { at inlet }\end{array}$ & $\begin{array}{l}V_{\min } \\
{[\mathrm{mm} / \mathrm{s}]}\end{array}$ & $\begin{array}{l}V_{\max } \\
{[\mathrm{mm} / \mathrm{s}]}\end{array}$ & $\begin{array}{l}P_{\min } \\
{[\mathrm{Pa}]}\end{array}$ & $\begin{array}{l}P_{\max } \\
{[\mathrm{Pa}]}\end{array}$ \\
\hline 3 & 2.1834 & 21.3 & 0.00372 & 4.87 & 0.999 & 3.92 \\
\hline 5 & 3.639 & 35.5 & 0.00011 & 10.48 & 0.999 & 9.60 \\
\hline 10 & 7.278 & 71.0 & 0.00021 & 20.08 & 0.992 & 18.43 \\
\hline 20 & 14.556 & 142.0 & 0.00084 & 41.26 & 0.935 & 37.02 \\
\hline 30 & 21.834 & 213.0 & 0.00016 & 61.26 & 0.789 & 57.06 \\
\hline
\end{tabular}

Table 13: Pressure difference for the Channel length

\begin{tabular}{|c|c|c|c|}
\hline \multirow{2}{*}{ Flow rate $[\mathrm{ml} / \mathrm{min}]$} & \multicolumn{2}{|c|}{ Pressure $[\mathrm{Pa}]$} & \multirow{2}{*}{$\Delta P[\mathrm{~Pa}]$} \\
\cline { 2 - 3 } & Beginning of channel & End of Channel & \\
\hline 3 & 3.578 & 1.347 & 2.231 \\
\hline 5 & 8.586 & 1.804 & 6.781 \\
\hline 10 & 16.313 & 2.787 & 13.53 \\
\hline 20 & 32.443 & 5.428 & 27.01 \\
\hline 30 & 49.650 & 7.801 & 41.85 \\
\hline
\end{tabular}




\section{A.3 Conclusion}

The pressure losses in a fuel cell strongly influence the performance overall efficiency of the fuel cell. The pressure drop in the fuel cell distributor plate depends on the plate configurations, and for a given serpentine channel configuration, it depends on geometric factors such as channel hydraulic diameter and bend geometry. It was found that by increasing flow velocity, pressure drop increases as well. This study showed that there is a significant effect of Reynolds number on the bend loss coefficient. Therefore it can be concluded that the bend losses constitute a significant portion of the overall pressure loss. 


\section{Appendix B}

\section{Drawings}

Note: all dimensions are in $\mathrm{mm}$ except the threaded dimensions that are in inches.

Copper Plate 2 and Graphite Plate 2 have the exact same dimensions as Copper Plate 1 and Graphite Plate 1, respectively (for their common features). 


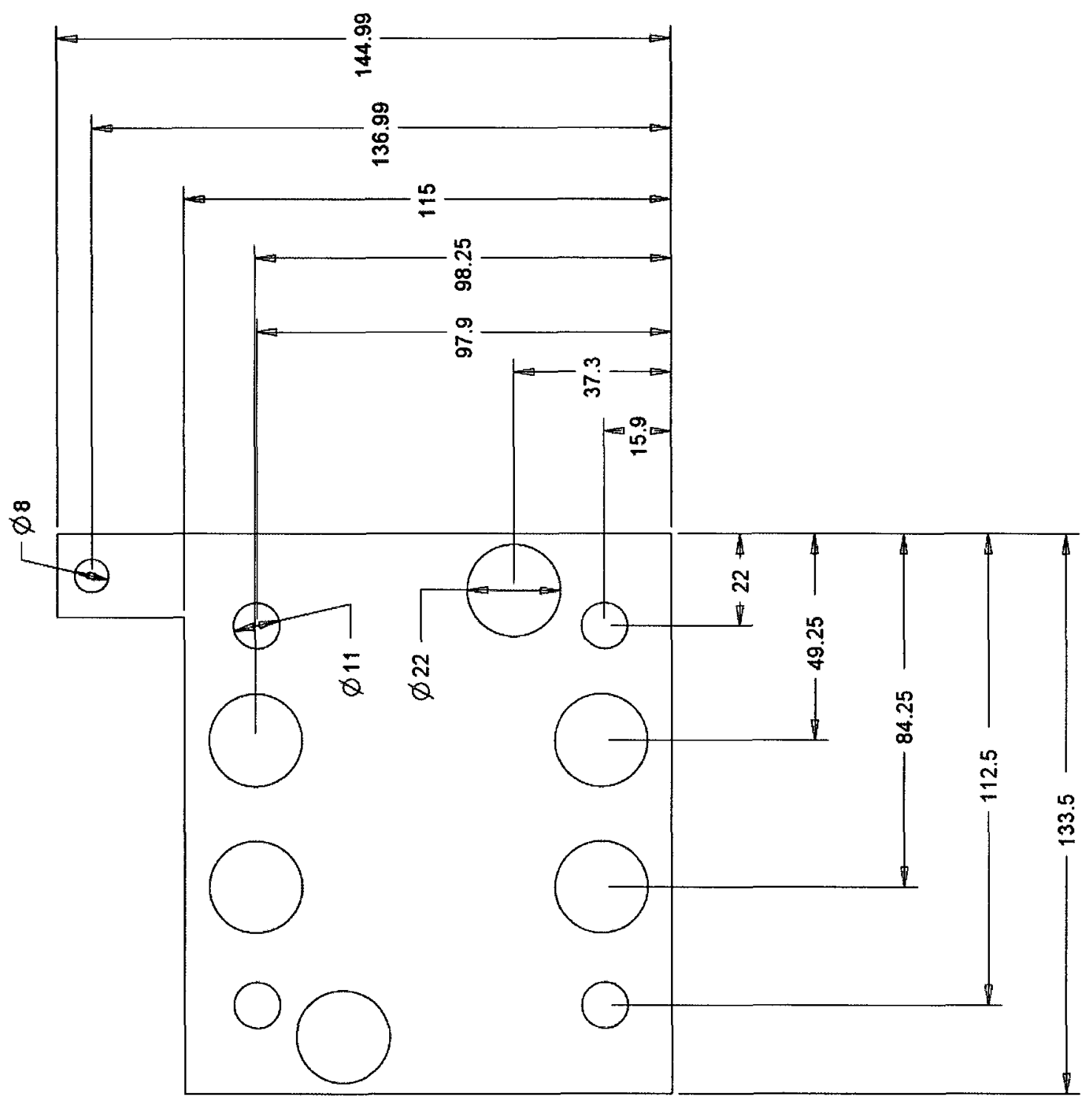

Figure 40: Copper Plate 1 drawing 


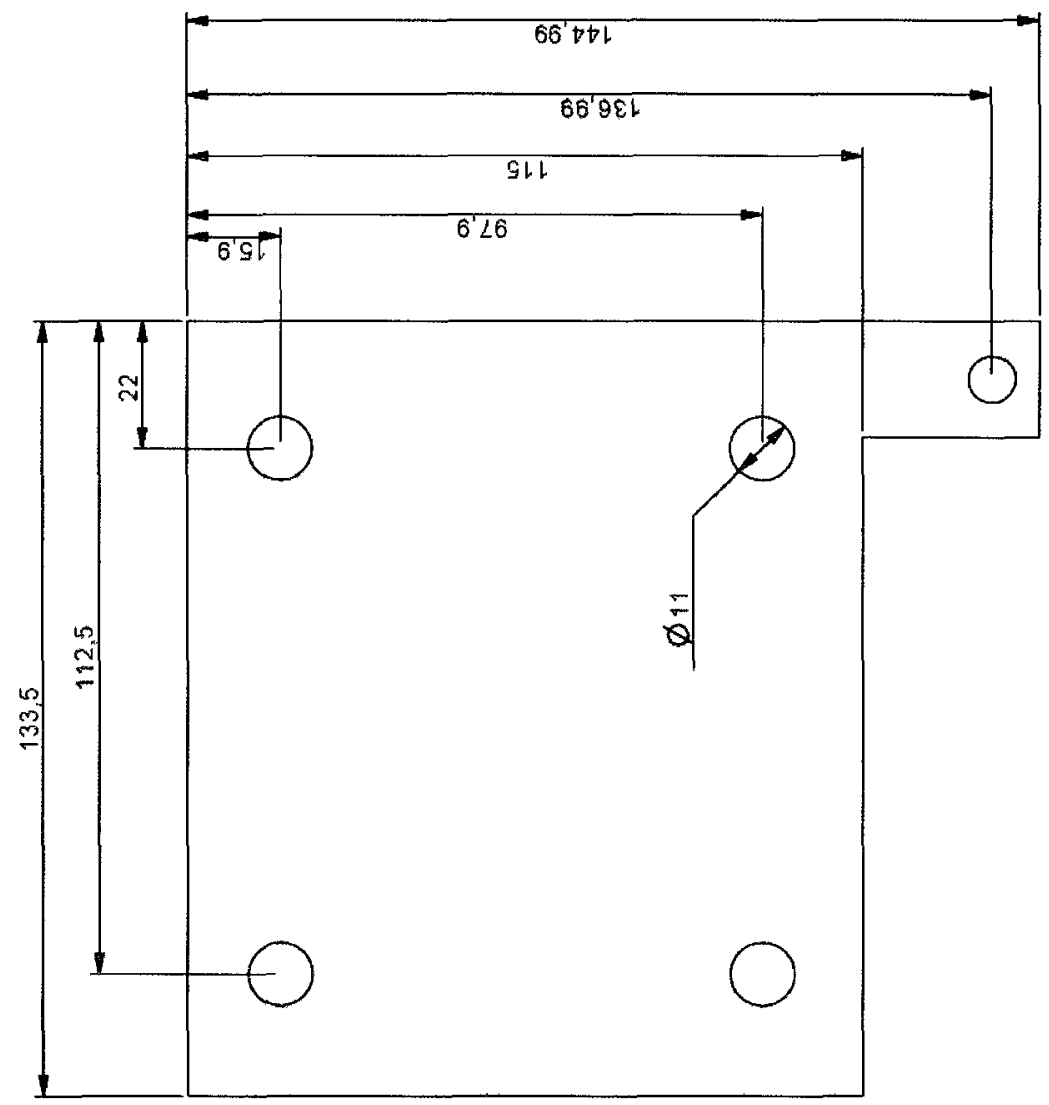

Figure 41: Copper Plate 2 drawing 

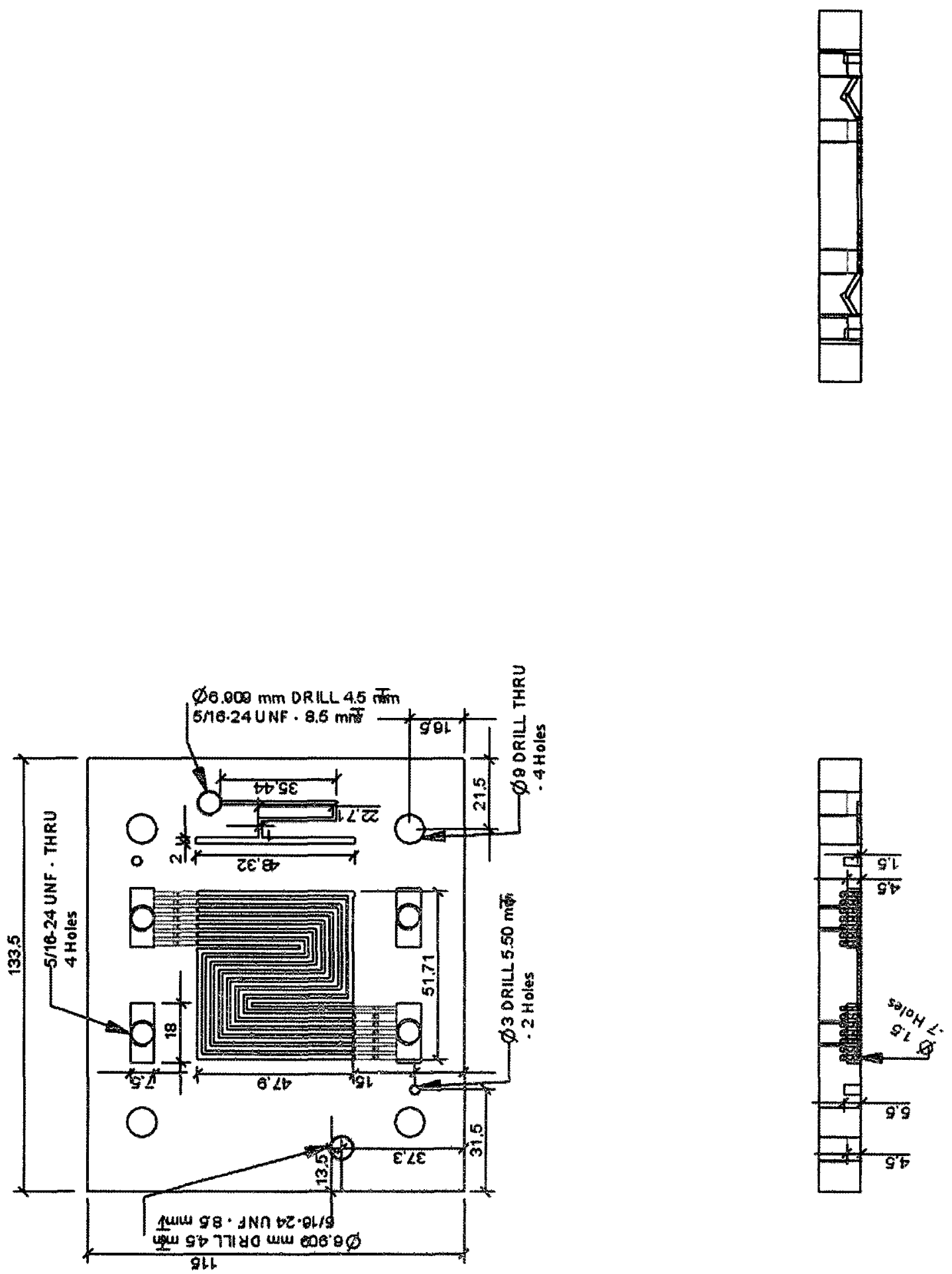

Figure 42: Graphite Plate 1 


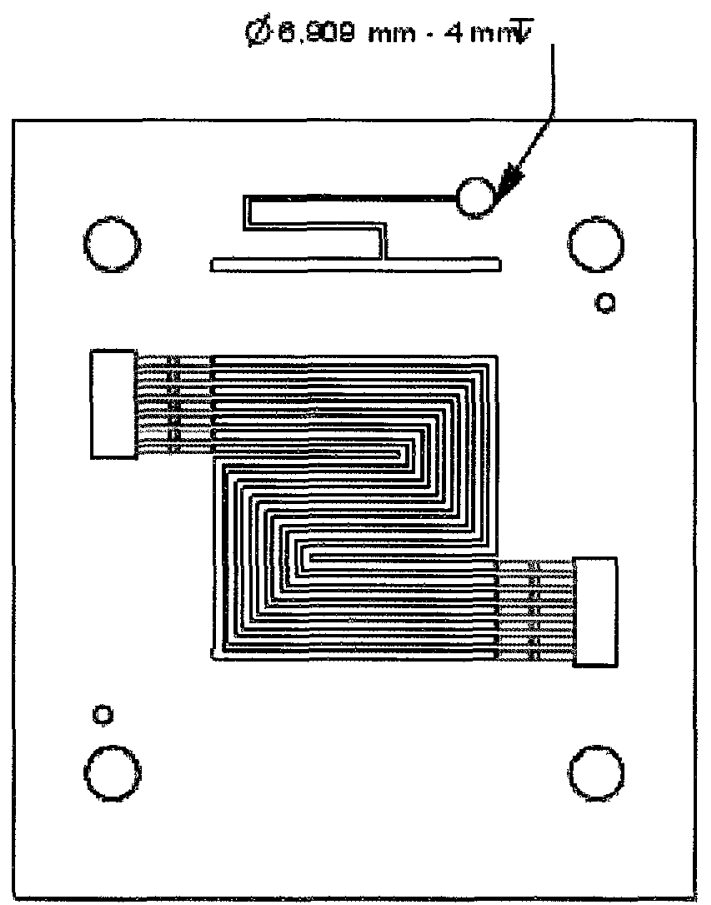

Figure 43: Graphite Plate 2 


\section{Appendix C}

\section{Temperature controller wiring}

A detailed drawing of the temperature controller wiring is presented in this section. Figure 44 shows a schematic of the wiring set up for the Omega CN-7900. The thermocouple wires are connected to Zone 1 and Zone 2. Output A and Output $\mathrm{B}$ provide power to the heaters. It should be noted that the Zone 1 and Zone 2 correspond to Output $\mathrm{A}$ and Output B, respectively. In this setup, the heaters are powered by the plug but the temperature controller is acting as a switch and would only allow the heater to turn on when the measured temperature by the thermocouple reaches below the limit, which is programmed into the temperature controller by the user. None of the temperature controllers or the heaters are polarized. The controller is powered through Pins 11 and 12. Guidelines on how to use this device are available in the user manual. 


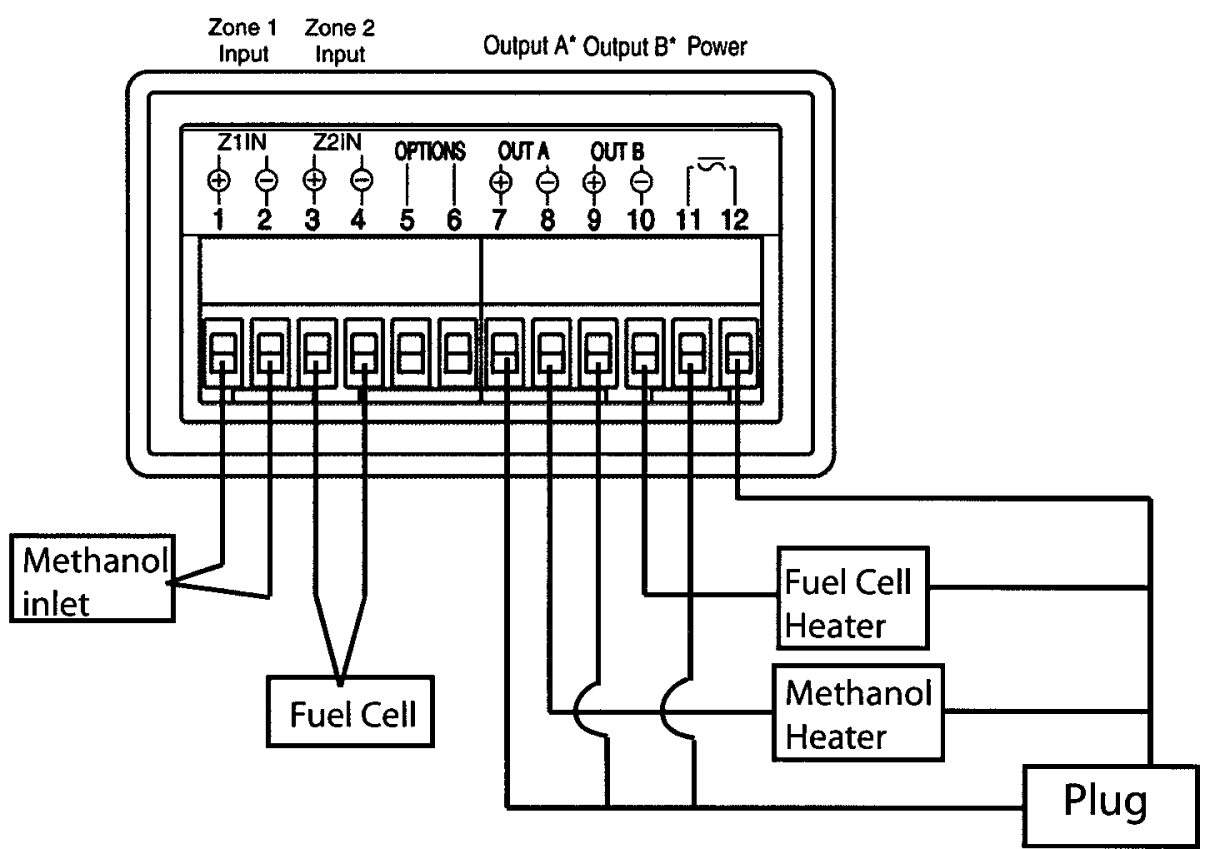

Figure 44: Temperature controller setup schematic 


\section{Appendix D}

\section{FC Power}

FC power is the software that was used to control the load bank. Figure 45 displays the main page of this program. The Navigation bar is on the left side of the window, where all the devices are listed in the Instruments tab. Monitors and Managers are the other two tabs under the Navigation bar (these will be explained later). The load bank is listed as the LoadControl. By double clicking on this icon, the LoadControl Full-Control window will open. In order to activate the load bank, the box beside the "Enable Electronic Load" should be enabled.

The load bank can control current, voltage, or power. The limiting specification of the load bank for each mode is listed in the Minimum and Maximum columns. The Setpoint is the target value that the fuel cell could be operated at when the Constant operating mode is activated. For example, if it is desired for the fuel cell to operate at $300 \mathrm{mV}$, voltage is selected and a setpoint of 300 is chosen.

There is also a Pulse operating mode, which allows the user to set two limits for the fuel cell. This option works similar to a step function. Therefore, the user can choose a lower and an upper limit and specify the duration of each step separately. 


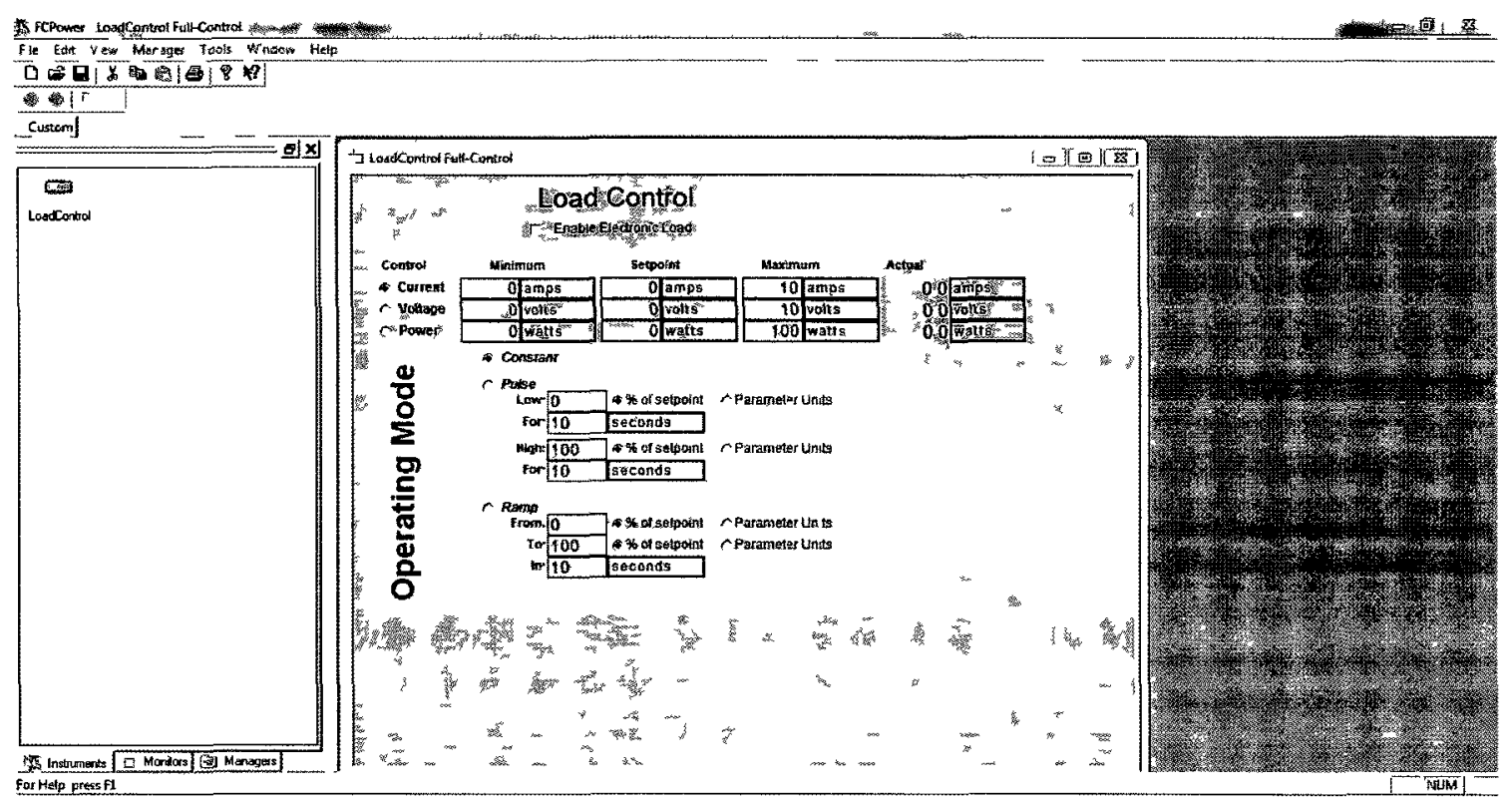

Figure 45: FC power

In the Ramp operating mode, the user can choose two limits for the load bank to sweep between, within a given time. For example, if the load bank is told to sweep between 0 and 1 amps in 5 minutes, the load bank starts with no load and adds small intervals of current to reach 1 amps in 5 minutes. Then, the load bank decreases back to 0 amps in a step before it starts sweeping again.

All charts and data logs can be found under the Managers tab (Figure 46). There are three tabs under Chart Sessions for each chart: General, X-Axis, and Y-Axis. The properties of the chart such as its name and number of data. are specified in the General tab. The variables associated with the $\mathrm{x}$-axis and $\mathrm{y}$-axis should be selected in their specific tabs. Log Sessions could also be created following the same procedure. It should be noted that in order to save a graph, either a snap shot should be taken at the appropriate time, or the graph has to be regenerated using the logged data in a separate program such as Excel. 


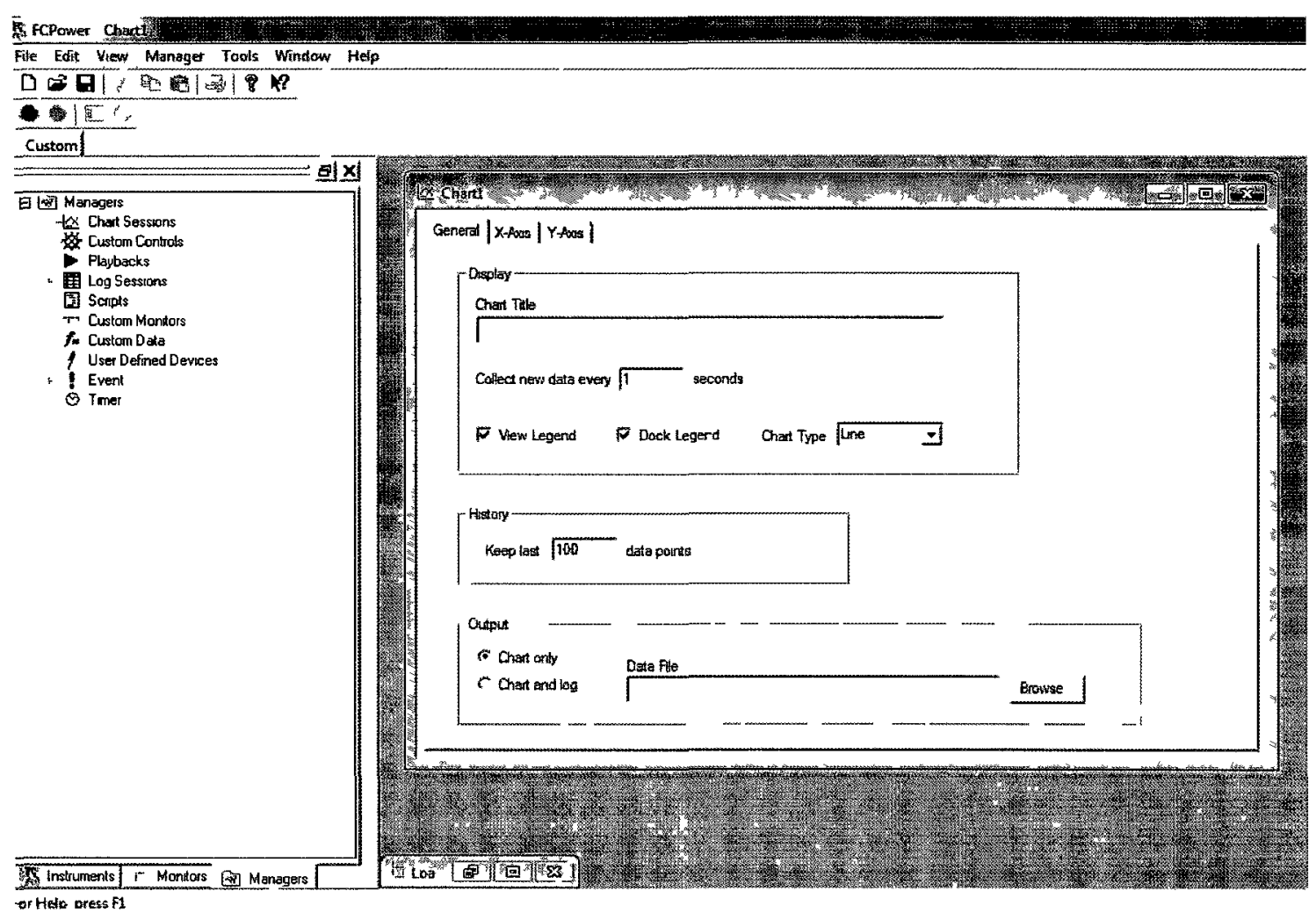

Figure 46: Creating charts

New variables could be created based on the basic variables that are provided by the software in the Custom Data section. Figure 47 shows the Costume Data window. For example, current and power densities are not provided in the basic variables by the software. Using the Custom Data, these variables could be created by clicking on the "Insert Var" and selecting the Actual Current which is read by the load bank and dividing that by the active area, which is $25 \mathrm{~cm}^{2}$ in our case.

Data logs could also be created by right clicking on the Log Session and selecting New. A similar window to Figure 48 will be opened. A log file can be saved by clicking on Browse and saving a file at a desirable location. Variables should be chosen from the Available Variables section in the appropriate order. 


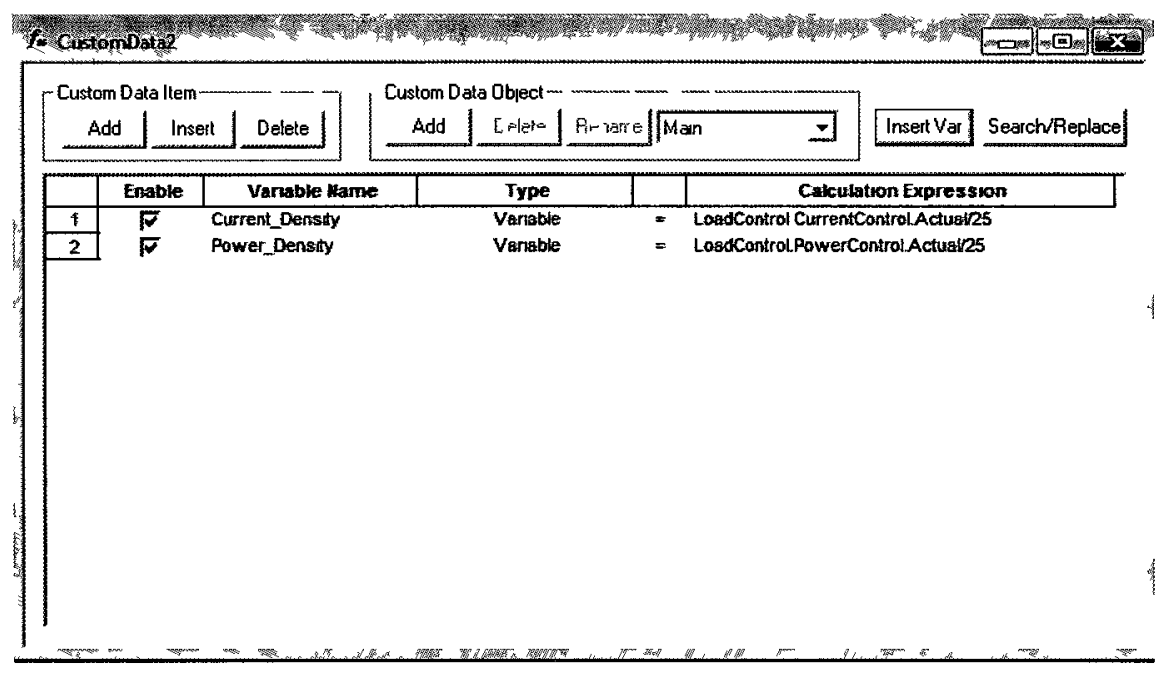

Figure 47: Creating custom data

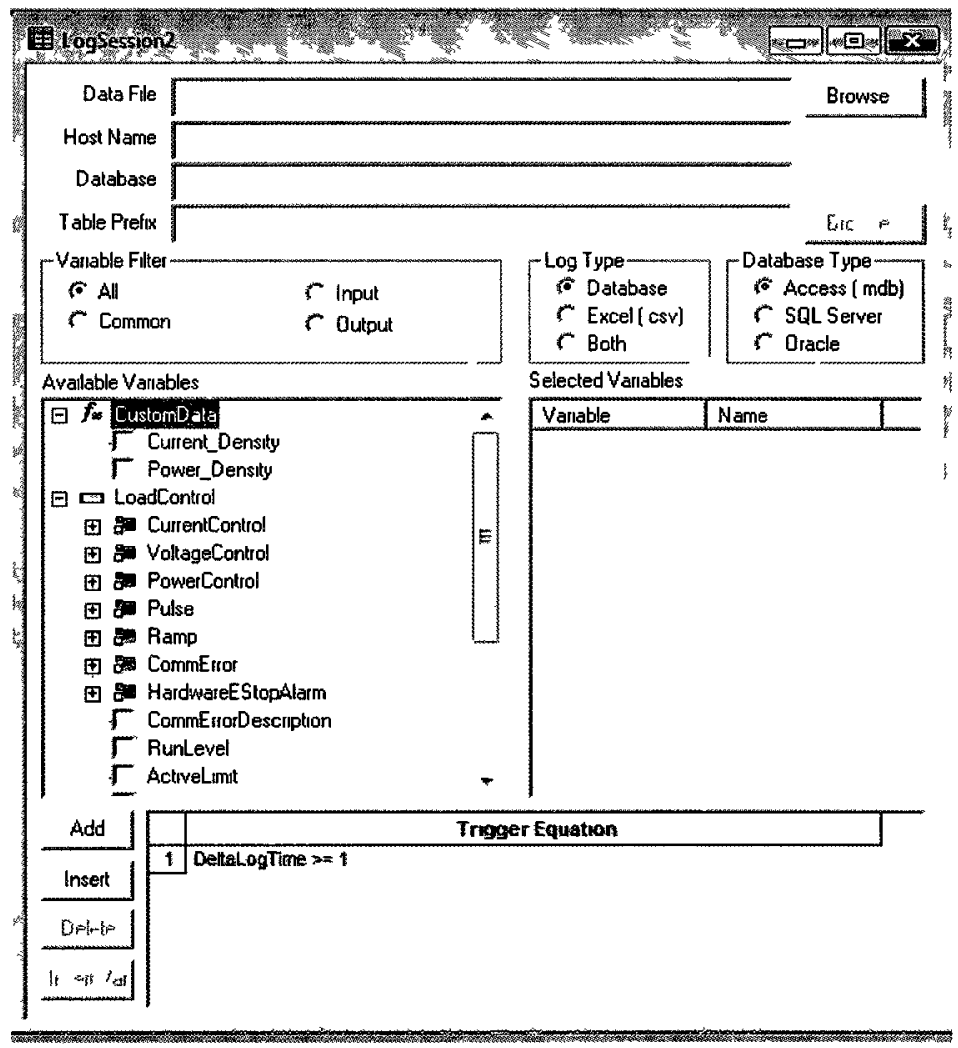

Figure 48: Creatıng log sessions 
In order to activate any of the sessions, right click on the session and select Start. Previous sessions can also be used by loading them back. 


\section{Appendix E}

\section{Uncertainty Analysis}

The ASME uncertainty analysis [55] method is described in this section.

\section{E.1 Definition of the measurement process}

The fuel cell is connected to the load bank which simulates the load and measures current and voltage from the fuel cell. The power generated by the fuel cell is then calculated using these data. This is defined as the measurement process.

\section{E.2 Listing of elemental error sources}

The elemental error sources includes thermocouple, thermocouple position, thermocouple controller, load bank, anode, cathode and flowing electrolyte flow rate, thickness of flowing electrolyte and anode, cathode and flowing electrolyte pressures.

\section{E.3 Estimation of elemental errors}

Table 14 contains the bias error (B) and the random error (S) for all the major contributors and also the effect of these errors on current density $\left(B_{I}, S_{I}\right)$ and voltage 
$\left(B_{V}, S_{V}\right)$. The temperature measurement error is due to several individual errors from the thermocouple $\left(B_{a}, S_{a}\right)$ and the controller $\left(B_{b}, S_{b}\right)$.

The anode and FE flow rates were both calibrated volumetrically by a graduated cylinder, which had a bias error of a $0.25 \mathrm{ml}$, which would result in a $0.25 \mathrm{ml} / \mathrm{min}$ for the flow rate. An equal random error was chosen to account for human eye error. The same equipment was used to measure the required amount of methanol and sulfuric acid for preparing the diluted solutions. The microporous polyethylene material (FE channel) was measured by a Mastercraft Electronic Caliper with a $0.02 \mathrm{~mm}$ accuracy before use. The load bank is accurately calibrated by the Fideris Inc. Therefore, the bias error is considered to be neglegible. The random error is considered to be much bigger due to the contact resistance that might be present because of the connections between the cables and the current collectors of the fuel cell.

It should be noted that the effects of the bias and the random errors on the current density and voltage are estimated based on the experiments done with the fuel cell. For this study, the measurement errors are as follows:

Thermocouple $B_{a}= \pm 2.2{ }^{\circ} \mathrm{C} \quad S_{a}= \pm 1{ }^{\circ} \mathrm{C}$ Temperature controller

$$
B_{b}= \pm 0.5^{\circ} \mathrm{C} \quad S_{b}= \pm 0.25{ }^{\circ} \mathrm{C}
$$

Overall temperature measurement error

$B_{c}=\left(2.2^{2}+0.5^{2}\right)^{\frac{1}{2}}=2.26 C$

$S_{c}=\left(1^{2}+0.25^{2}\right)^{\frac{1}{2}}=1.03 C$

The estimated error based on values in Table 14:

Total bias error on current and voltage: 
Table 14: Error analysis

\begin{tabular}{|l|l|l|l|l|l|l|}
\hline & $B$ & $\begin{array}{l}B_{I} \\
{\left[\mathrm{~mA} / \mathrm{cm}^{2}\right]}\end{array}$ & $\begin{array}{l}B_{V} \\
{[\mathrm{mV}]}\end{array}$ & $S$ & $\begin{array}{l}S_{I} \\
{\left[\mathrm{~mA} / \mathrm{cm}^{2}\right]}\end{array}$ & $S_{V}[\mathrm{mV}]$ \\
\hline $\begin{array}{l}\text { Temperature } \\
{\left[{ }^{\circ} \mathrm{C}\right]}\end{array}$ & 2.26 & 2 & 10 & 1.03 & 1 & 5 \\
\hline $\begin{array}{l}\text { Anode flow } \\
\text { rate }[\mathrm{ml} / \text { min }]\end{array}$ & 0.25 & 0.1 & 1 & 0.25 & 0.1 & 1 \\
\hline $\begin{array}{l}\text { FE flow rate } \\
{[\mathrm{ml} / \text { min }]}\end{array}$ & 0.25 & 2.5 & 5 & 0.25 & 2.5 & 5 \\
\hline $\begin{array}{l}\text { Cathode flow } \\
\text { rate }[\mathrm{ml} / \text { min }]\end{array}$ & 20 & 0.01 & 0.1 & 50 & 0.01 & 0.1 \\
\hline $\begin{array}{l}\text { FE thickness } \\
{[\mathrm{mm}]}\end{array}$ & 0.02 & 0.5 & 2 & 0.1 & 2.5 & 10 \\
\hline $\begin{array}{l}\mathrm{FE} \text { pressure } \\
{[\mathrm{Psi}]}\end{array}$ & 0.03 & 0.1 & 0.5 & 0.1 & 0.5 & 1.5 \\
\hline $\begin{array}{l}\text { Compression } \\
\text { torque } \\
{[N-m]}\end{array}$ & 0.1 & 0.5 & 0.2 & 0.5 & 2.5 & 1 \\
\hline $\begin{array}{l}\text { Methanol } \\
\text { concentration } \\
{[\mathrm{M}]}\end{array}$ & 0.05 & 0.5 & 2.5 & 0.05 & 0.5 & 2.5 \\
\hline $\begin{array}{l}\text { FE Con- } \\
\text { centration } \\
{[\mathrm{M}]}\end{array}$ & 0.05 & 0.5 & 2.5 & 0.05 & 0.5 & 2.5 \\
\hline Load bank & - & 0.05 & 0.5 & - & 0.5 & 5 \\
\hline
\end{tabular}




$$
\begin{aligned}
& B_{I}=\left(2^{2}+0.1^{2}+2.5^{2}+0.01^{2}+0.5^{2}+0.1^{2}+0.5^{2}+0.5^{2}+0.5^{2}+0.05^{2}\right)^{\frac{1}{2}} \\
& B_{I}=3.3 \mathrm{~mA} / \mathrm{cm}^{2} \\
& B_{V}=\left(10^{2}+1^{2}+5^{2}+0.1^{2}+2^{2}+0.5^{2}+0.2^{2}+2.5^{2}+2.5^{2}+0.5^{2}\right)^{\frac{1}{2}} \\
& B_{V}=9.6 \mathrm{~V}
\end{aligned}
$$

Total random error on current and voltage:

$$
\begin{aligned}
& S_{I}=\left(1^{2}+0.1^{2}+2.5^{2}+0.01^{2}+2.5^{2}+0.5^{2}+2.5^{2}+0.5^{2}+0.5^{2}+0.5^{2}\right)^{\frac{1}{2}} \\
& S_{I}=6.2 \mathrm{~mA} / \mathrm{cm}^{2} \\
& S_{V}=\left(5^{2}+1^{2}+5^{2}+0.1^{2}+10^{2}+1.5^{2}+1^{2}+2.5^{2}+2.5^{2}+5^{2}\right)^{\frac{1}{2}} \\
& S_{V}=14.05 \mathrm{~V}
\end{aligned}
$$

\section{E.4 Propagation of bias and precision errors}

The equation to calculate the power density is:

$P=I V$

Therefore, the propagated bias and random error are obtained:

$S_{P}=\left[\sum_{i=1}^{j}\left(\theta_{i} S_{p_{i}}\right)^{2}\right]^{\frac{1}{2}}$

$S_{p}=\left[\left(\theta_{I} S_{I}\right)^{2}+\left(\theta_{V} S_{V}\right)^{2}\right]^{\frac{1}{2}}$

where $\theta_{I}=\frac{\partial p}{\partial I}$ and $\theta_{V}=\frac{\partial p}{\partial V}$

Therefore,

$S_{p}=\left[\left(\frac{S_{I}}{I}\right)^{2}+\left(\frac{S_{V}}{V}\right)^{2}\right]^{\frac{1}{2}}$

Similarly,

$B_{p}=\left[\left(\frac{B_{I}}{I}\right)^{2}+\left(\frac{B_{V}}{V}\right)^{2}\right]^{\frac{1}{2}}$ 
For Maximum power density, $I=136.3 \mathrm{~mA} / \mathrm{cm}^{2}$ and $V=247.4 \mathrm{mV}$,

$$
\begin{aligned}
& S_{p}=\left[\left(\frac{4.6}{136.3}\right)^{2}+\left(\frac{13.8}{247.4}\right)^{2}\right]^{\frac{1}{2}}=0.065 \\
& B_{p}=\left[\left(\frac{3.36}{136.3}\right)^{2}+\left(\frac{11.96}{247.4}\right)^{2}\right]^{\frac{1}{2}}=0.054
\end{aligned}
$$

\section{E.5 Calculate uncertainty}

The total uncertainty could be calculated using the following equations.

$U_{A D D}=B+t S_{x}$, which provides up to $99 \%$ coverage

$U_{A D D}=0.054+(2 \times 0.065)=18.4 \%$

$U_{R S S}=\left[B^{2}+\left(t S_{x}\right)^{2}\right]^{\frac{1}{2}}$, which provides up to $95 \%$ coverage

$U_{R S S}=\left[0.054^{2}+(2 \times 0.065)^{2}\right]^{\frac{1}{2}}=14.1 \%$

Therefore, the uncertainty analysis indicates that the $99 \%$ and $95 \%$ confidence levels are $18.5 \%$ and $14 \%$ for maximum power density, where current density is $136.3 \mathrm{~mA} / \mathrm{cm}^{2}$ and voltage is $247.4 \mathrm{mV}$. It should be noted that the current analysis is based on the experiments done on the first generation of the FE-DMFC. Factors such as catalyst loading, graphite conductivity, PEM proton conductivity based on relative humidity and many other factors should be studied in the future. 